\title{
Late Silurian (Ludlow) and Early Devonian (Pragian) conodonts from the Cobar Supergroup, western New South Wales, Australia
}

\author{
DAVID MATHIESON, RUth MAWSON, ANDREW J. SIMPSON \& JOHN A. TALENT
}

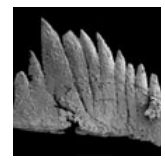

Late Silurian and Early Devonian conodonts are documented from outcropping limestones at nine Cobar Supergroup localities: the Booth Limestone, the Mountain Dam Limestone, the Beloura Tank Limestone Member of the Baledmund Formation, the "Lerida Limestone Member" of the Amphitheatre Group, and limestones in Stoney Creek in the Gundabooka National Park, in the Troffs Formation in the Trundle Group and in the Derriwong Group at Myola. These (with the exception of Myola) and conodonts previously documented from the White Tank and Rookery limestone members of the Meryula Formation are Pragian in age, ranging from sulcatus Zone to the imprecisely defined pireneae Zone, with the uppermost part of one of them (the Booth Limestone) possibly extending into the earliest Emsian. The Derriwong Group carbonates are late Ludfordian, crispa Zone, in age and are the only remnants discovered to date of a Silurian marine incursion. Ages for the Devonian limestones are: Booth Limestone, late in the sulcatus Zone to "pireneae Zone" with the uppermost horizon possibly extending into the dehiscens Zone; Mountain Dam Limestone, sulcatus Zone with the uppermost preserved horizon inferred to have been late in the sulcatus Zone; the Beloura Tank Limestone Member, sulcatus Zone; the ?olistoliths constituting the "Lerida Limestone Member", sulcatus Zone; and limestones in Stoney Creek in the Gunderbooka National Park, "pireneae Zone". Conodonts previously documented from "The Rookery" - the White Tank and Rookery limestone members - are inferred to be sulcatus Zone. In terms of recently refined absolute ages, Devonian carbonate sedimentation in the Cobar Supergroup, though localised, thus spans a six-or-seven-million-year time slice. The Devonian limestones investigated were apparently deposited during a single, basin-wide sedimentary event that was conducive to accumulation of carbonate sediments at various loci. Several conodont species documented here are taxa found in Central Asia and Arctic North American localities. Previous examples of such apparent provincialism, based on conodont distribution, have been noted to occur in faunas from the pesavis and kindlei zones, the imprecisely defined pireneae interval, and now for the sulcatus Zone. A plethora of new species and subspecies identified from the Cobar Supergroup limestones appear in the middle to late portion of the sulcatus Zone, an interval from which conodonts have not been documented as copiously as from other time slots globally. New conodont taxa consist of one new genus, eight new species - one kept in open nomenclature - and six new subspecies: Heliagnathus gen. nov. (type species Heliagnathus parvilabiatus sp. nov.), Panderodus rhytiodus sp. nov., Panderodus sp. nov. A, Icriodus ampliatus sp. nov., Pelekysgnathus inaequalis sp. nov., Oulodus astriatus sp. nov., Ozarkodina multistriola sp. nov., Ozarkodina scoliciformis sp. nov., Amydrotaxis corniculans truncus subsp. nov., Eognathodus sulcatus lanei subsp. nov., Eognathodus sulcatus sicatus subsp. nov., Ozarkodina selfi lenticula subsp. nov., Ozarkodina selfi lanceola subsp. nov. and Ozarkodina selfi cordata subsp. nov. Biostratigraphic data from this study indicate a separation in the ranges of Ozarkodina selfi and Eognathodus sulcatus. A polyphyletic origin of Eognathodus is suggested. Biometric data are presented to demonstrate that Icriodus ampliatus sp. nov. occupies a morphological gap between I. steinachensis and I. claudiae and its first appearance is a marker of the upper sulcatus zone. • Key words: Australia, New South Wales, Cobar Supergroup, late Silurian, Early Devonian, conodonts, conodont phylogeny, Darling Basin.

MAthieson, D., MAwson, R., Simpson, A.J. \& TAlent, J.A. 2016. Late Silurian (Ludlow) and Early Devonian (Pragian) conodonts from the Cobar Supergroup, western New South Wales, Australia. Bulletin of Geosciences 91(3), 583-652 (32 figures, 3 tables). Czech Geological Survey, Prague. ISSN 1214-1119. Manuscript received October 23, 2015; accepted in revised form September 23, 2016; published online November 24, 2016; issued November 25, 2016.

David Mathieson, Department of Earth and Planetary Sciences, Macquarie University, North Ryde 2109, Australia; david.mathieson@mq.edu.au • Ruth Mawson, Department of Earth and Planetary Sciences, Macquarie University, North Ryde 2109, Australia; rmawson37@gmail.com • Andrew J. Simpson (corresponding author), Department of Ancient History, Macquarie University, North Ryde 2109, Australia; andrew.simpson@mq.edu.au • John A. Talent, Department of Earth and Planetary Sciences, Macquarie University, North Ryde 2109, Australia; jatalent32@ gmail.com 
The Cobar Basin of western New South Wales (Fig. 1), flanking and perhaps viewed as continuing imperceptibly westwards into the largely subsurface Darling Basin (Talent et al. 2000), has been regarded traditionally as a NNW-trending half-graben formed during a regional crustal extension event. This event (or aggregate of events) is believed to have occurred during the latest Silurian to Early Devonian, affecting the western portion of the Lachlan Fold Belt in New South Wales (Glen 1990, 1991; Smith \& Marshall 1992). The Cobar Basin has been viewed as having been flanked by shallow shelves separated by faults (Fig. 1) (Trigg 1987; MacRae 1989a, b; Glen 1990, 1991; Glen et al. 1994, 1996; Gilligan \& Byrnes 1995).

The latest Silurian to Early Devonian Cobar Supergroup (Pogson \& Felton 1978) is viewed as having accumulated within the inferred Cobar Basin including its flanking shelves. Associated with these inferred shelves are small, shallow-water limestone bodies that were sampled for conodonts (primarily) and associated fauna. The limestones crop out in nine discrete areas (six are shown in Fig. 1, all nine are shown in Fig. 2) about $500 \mathrm{~km} \mathrm{NW}$ of Sydney. A further occurrence of limestones, on a property known as "The Rookery", about 35 km SE of Cobar, was cursorily examined; it has already been the focus of a significant conodont investigation by Pickett (1980). Another limestone occurrence - on Kopyje station, $70 \mathrm{~km}$ ESE of Cobar - produced 43 rather nondescript conodonts from a 12 kg sample, suggesting a late Přídolí age (Pickett 1976), but access to this property for further investigation as part of this study was refused.

During the 1980s and early 1990s, as a service to exploration companies and geologists of the Geological Survey of New South Wales mapping in the Bourke-Cobar-Condobolin region, Pickett produced a series of brief reports with identifications but not documentation of fossils (mainly conodonts) from spot samples (Pickett 1981, 1982, 1983, 1984, 1986, 1987, 1992). Because scores of stratigraphic units have been proposed for this vast region of Ordovician to Late Devonian clastics and occasional volcanics - most without a glimmer of compelling age control - no attempt is made herein to rationalise the stratigraphic fabric regionally nor attempt to chronicle and interpret its tectonostratigraphic evolution.

Largely because of mineral exploration, the literature is vast and diffuse but an overview of the palaeogeography of the region during Early Devonian time (Trigg 1987) provides a useful backdrop (Fig. 1) for considering the hypothesised sedimentary-tectonic settings of the areas probed for improved data from conodonts and their chronologic implications. That the areas lacking useful outcrop are vast, that the suggested palaeogeographic pattern is conjectural, and that the dearth of fossil localities providing even the most basic age control has been disheartening, should not be underestimated.
Most attention has been directed to the taxonomy of the $6000+$ conodonts obtained from acid leaching using commercial acetic acid, and to evaluating their significance as regards stratigraphic alignments; they are comprehensively illustrated in Figs 8-32. Outcrops of Booth Limestone, especially in the vicinity of Beulah Tank on "Manuka" (Fig. 3), have produced poorly preserved (recrystallized, dolomitised, often rusty coloured) massive algae and stromatoporoids, but well preserved stromatoporoids are found on the eastern side of the strip of Booth Limestone along the Multagoona Anticline (Fig. 3); these are being investigated by Barry Webby. Inarticulate brachiopods and fish micro-remains obtained in acid leaching for conodonts have been made available to other workers and are not considered here. The generally sparse conodont faunas obtained from bores in the Darling Basin are discussed by Talent et al. (2003).

Of special interest are small occurrences of silicification at five spot localities in the Booth Limestone: 14, 15, $15 \mathrm{E}, 15 \mathrm{~W}$ and 16A. Exhaustive collections from these spots, acid-leached with commercial acetic and dilute hydrochloric acid, have produced silicified rugose and tabulate corals, brachiopods and rare rostroconchs, ostracods and other organisms. These were illustrated by Mathieson (2006) and will be documented separately. No attempt has been made to study the sedimentary petrology of the various limestone occurrences.

\section{Stratigraphic units investigated for conodonts}

The outcropping limestones sampled in this study are noted below, and their latitudes and longitudes are given in Table 1.

\section{Booth Limestone}

Previously this unit has been referred to as the Booth Limestone Member of the Gundaroo Sandstone (MacRae 1989a, b). Though generally poorly exposed, this unit clearly overlies the Thule Granite nonconformably and is overlain in turn by the Gundaroo Sandstone (Fig. 3). Because it is substantial and conspicuous in the regional stratigraphy, the unit is herein regarded as a formation independent from the Gundaroo Sandstone.

The relationship between the Thule Granite, Booth Limestone and Gundaroo Sandstone is seen in two small north-west to south-east trending anticlinal structures (Fig. 3) that are informally named after local properties. Along the Manuka Anticline (new name), NNW from Beulah Tank, the Booth Limestone reaches a stratigraphic thickness of between 50 and $170 \mathrm{~m}$. The maximum development of dolomitised limestones (often weathering rusty 
David Mathieson et al. • Late Silurian and Early Devonian conodonts from the Cobar Supergroup

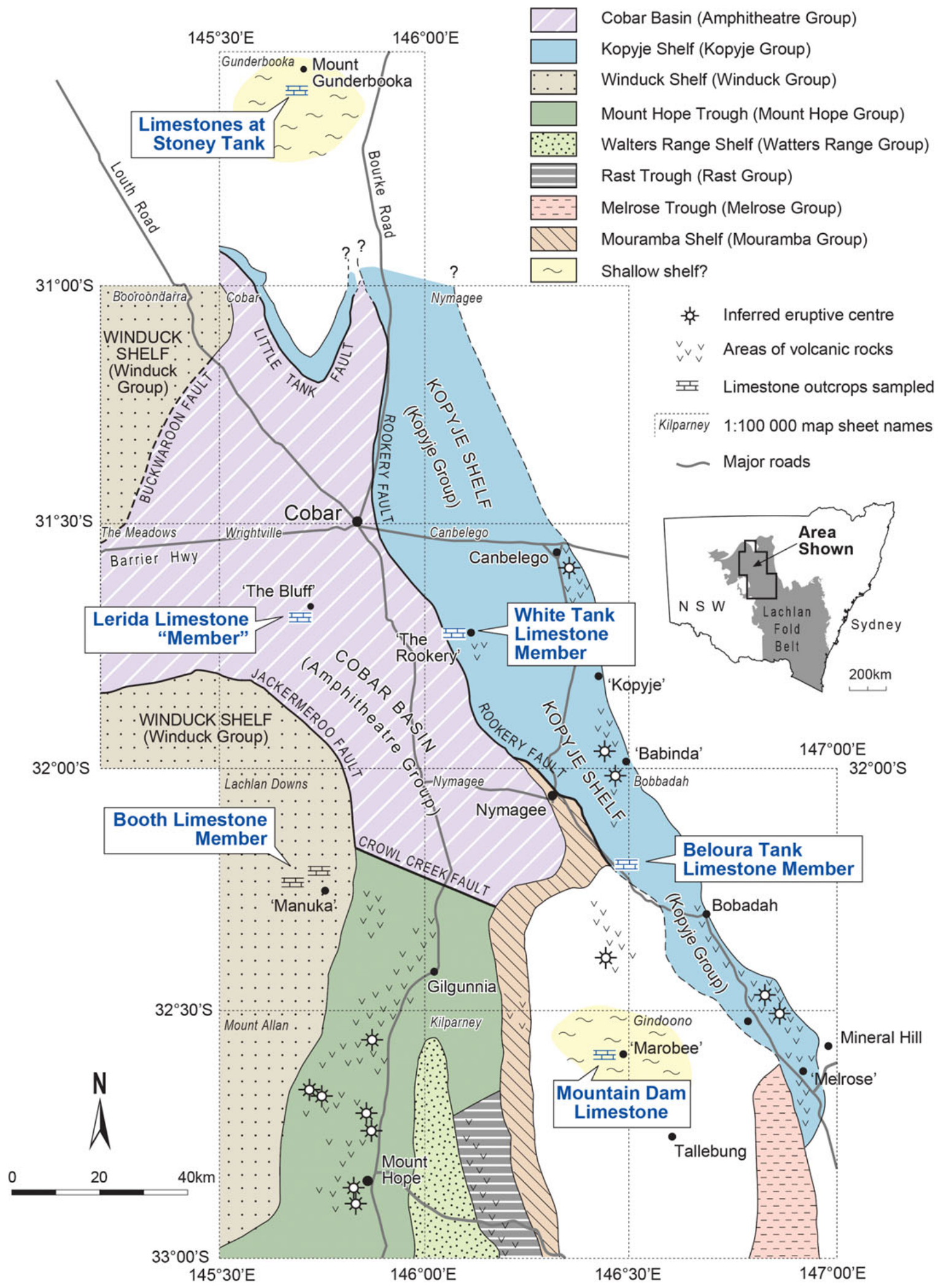

Figure 1. Sedimentary-tectonic interpretation of the Cobar Supergroup and adjacent areas from Trigg (1987) with locations of six of the areas considered in this study. Note that the "Lerida Limestone Member" is located in a region interpreted by Trigg as basinal, the Booth Limestone and the Beloura Tank and Rookery (= White Tank) limestone members in areas interpreted as shelf, and the Mountain Dam Limestone and Stoney Tank limestones in regions thought to be possibly shallow shelf. 
brown) with abundant massive calcareous algae, stromatoporoids and tabulate corals occurs in that area. The greater thickness than elsewhere, the dolomitisation and the abundance of frame-building organisms accords with the area having been very shallow - perhaps even including a transient palaeo-island or two - during Pragian times. It is also possible that the area included a locus or loci of carbonate buildup. These suggestions are speculative; the outcrops are poor and there is little in the way of dip information.

The generally very poorly outcropping tract of limestones along the Multagoona Anticline (new name), about $2 \mathrm{~km}$ west and southwest of the Manuka Anticline, could be interpreted as a lenticular development within the Gundaroo Sandstone, but conodont data from this occurrence (see later) and the very limited dip data accord best with this outcrop tract being interpreted as an anticlinal repeat of the Booth Limestone. Conodont faunas from these limestones (mostly from small clasts in the soil) display no significant differences. The calcareous algae, stromatoporoids and tabulate corals are better preserved in this tract than in the limestones outcropping in the vicinity of Beulah Tank. The Thule Granite is not exposed along the Multagoona Anticline so no estimate can be made of the thickness of the Booth Limestone in that area. Fifteen conodont samples were collected in the vicinity of the Manuka Anticline and seven in the vicinity of the Multagoona Anticline; their field locations are shown on Fig. 3.

\section{Mountain Dam Limestone}

The Mountain Dam Limestone (Rayner 1969) is an isolated outlier of fine-grained Cobar Supergroup limestone resting unconformably on the Ordovician Tallebung Group. It crops out as a low hill about 90 km NW of Condobolin (Fig. 4A) and about 2 km NW from "Marobee" homestead. The limestones are subhorizontal, determined from geopetal orientations, rather than subvertical as previously suggested (Pickett 1983); they aggregate about $11.5 \mathrm{~m}$ in thickness, based on a measured and sampled section variously offset to embrace the best outcrops. The stratigraphic column presented here (Fig. 4A) is a composite of two sections measured and sampled on the assumption of near verticality of the exposed sequence. Geopetal data subsequentlyindicated, however, that the exposed sequence was in fact horizontal. The limestones are abundantly fossiliferous, with stromatoporoids, massive calcareous algae, and tabulate and rugose corals, indicating very shallow platform conditions (Trigg 1987). Shelly fossils, apart from indeterminate gastropods, are rare. There were 39 samples collected for conodonts, 37 that were originally considered to come from a short stratigraphic interval, plus two additional spot samples. These samples produced a re- latively abundant and diverse conodont fauna (Table 2 online appendix).

\section{Stoney Creek limestones, Gunderbooka National Park}

Limestones crop out intermittently in Stoney Creek, north of Stoney Tank in the Gundabooka National Park, approximately 70 km SW of Bourke (Mulholland 1940; Figs 1, 2). The poorly outcropping sequence consists of argillaceous, quartzose and calcareous sandstones and siltstones with rare, thin, grey limestone horizons a few centimetres thick. The fauna consists of stromatoporoids, tabulate corals, brachiopods, crinoid ossicles, bivalves, ostracods, conodonts and rarely bryozoans (Mulholland 1940, Sharp 1992). An early Lochkovian age was suggested on the basis of a low diversity conodont fauna (Pickett 1987).

Six spot samples (GUND 1 to 6) were collected from the tiny exposures along Stoney Creek (Fig. 4B). Of these, samples GUND 1 to 5 yielded inarticulate brachiopods, mainly fragments of discinids. Samples GUND 1 and 5 were from a limestone horizon with abundant crinoid ossicles and brachiopods; these were the stratigraphically lowest samples collected. GUND 2 and 4 were from thin beds (1-5 cm thick) of muddy limestone interbedded with mudrocks. GUND 4 was stratigraphically the highest sample. GUND 3 and 6 were loose blocks of muddy limestone. Five of these samples produced conodonts (Table 3- online appendix).

\section{Beloura Tank Limestone Member of the Baledmund Formation}

First identified by Curran (1888), the Beloura Tank Limestone Member (Pogson \& Felton 1978; modified after Lloyd 1936) is a massive crinoidal limestone cropping out as a low hill approximately $20 \mathrm{~km}$ SE of Nymagee (Fig. 5A). It is believed to be conformably enclosed within the siltstones and fine-grained sandstones of the Baledmund Formation. It has produced numerous fossils including crinoids, rugose and tabulate corals, conodonts and brachiopods (MacRae 1987). Only three samples representing two localities were collected for conodonts: BTL 1 (BTL A is the same locality collected during initial field work) and BTL 2.

\section{"Lerida Limestone Member"}

The name Lerida Limestone Member was proposed by Glen (1987) for four small, rounded outcrops of massive, fine-grained limestone (Fig. 5B) inferred to occur within 

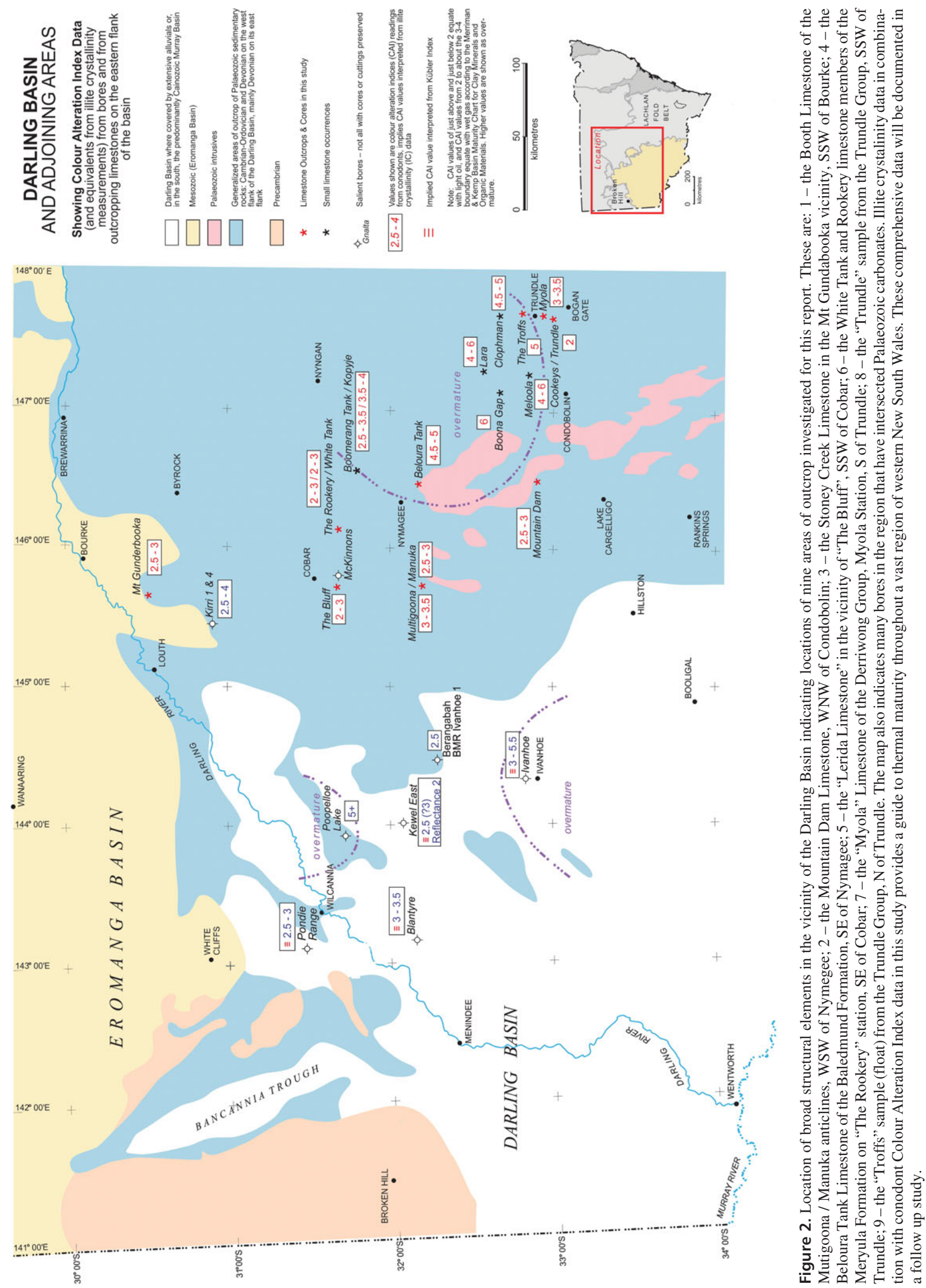
arenites of the lower Amphitheatre Group on "The Bluff", about $25 \mathrm{~km}$ SSW of Cobar. Stromatoporoids, rugose corals, trilobites, conodonts, bivalves and crinoid ossicles have been reported but not documented (Sherwin 1975, 1978a, b, 1980, 1995; Pickett 1979, 1981; Glen 1987). The lower Amphitheatre Group sandstones are either massive or show graded bedding, and are parallel- or cross-ripple laminated. These features accord with a turbiditic origin. The Lerida Limestone Member may thus be allochthonous in origin, representing limestone olistoliths shed from the Winduck Shelf to the west (based on palaeocurrent directions), or a more local, but now lost, palaeotopographic high (Glen 1987). Because of its probable allochthonous nature, the "Lerida Limestone Member" is referred to with inverted commas. Five spot samples (BLUFF 1 to 5) from three of these limestone bodies (Fig. 5B) produced conodonts (Table 3) as well as four species of inarticulate brachiopods.

\section{White Tank and Rookery Limestone members of the Meryula Formation on "The Rookery" station}

Outcrops of limestones on "The Rookery" station (Fig. 6), approximately $35 \mathrm{~km} \mathrm{SE}$ of Cobar (Pickett 1980), have been grouped into two lithologically dissimilar members assumed to be conformably enclosed within siltstones of the Meryula Formation (Felton 1981). The White Tank Limestone Member was described by Felton (1981) as consisting of massively bedded, autochthonous coralline and stomatoporoidal limestones interpreted as a forereef facies grading laterally into well-bedded calcarenites and calcirudites of the Rookery Limestone Member -interpreted as backreef facies. Because the conodonts of these two units have been documented (Pickett 1980), our consideration of them has been limited to a cursory examination of the outcrops, reappraisal of the taxonomy of the forms illustrated by Pickett (1980) and reconsideration of their age-significance.

\section{"Myola" Limestone}

Limestones interpreted as part of the Derriwong Group have been previously reported from the vicinity of "Myola" station (Pickett \& Ingpen 1990). These are considered part of the uppermost unit of the group, which consists of siltstones, minor sandstone and interbedded limestone. Pickett \& Ingpen (1990) indicated that the Derriwong Group is separated by unconformities from the underlying Raggart Volcanics and the overlying Hervey Group. They (Pickett \& Ingpen 1990, p. 9) used macrofossils to infer a broad correlation with the Quidong Limestone of far southeastern New South Wales.
For the present study, samples were collected from the roadside locality of Pickett \& Ingpen (1990) as well as from a small number of isolated limestones on the "Myola" property itself (samples Myola 1 to 5). It is not possible to infer stratigraphic relationships between these samples on field evidence alone. It was thought they might represent a very small number of penecontemporaneous late Silurian limestone shelf deposits, or remnants of a single deposit. Our study reveals a slightly more diverse conodont fauna of approximately the same age as suggested by Pickett \& Ingpen (1990). Subsequent investigations of areal imagery indicate that all the samples taken from "Myola" came from localities in close proximity to one another along strike.

\section{Trundle and Troffs samples}

The Trundle Group is an extensive sequence of mid-Palaeozoic clastic, volcaniclastic and volcanic rocks exposed in the region of the New South Wales township of Trundle. Two primarily clastic units have been identified: the lower Connemarra Formation and the upper Troffs Formation (Sherwin 1996). The latter is described as a sequence of fine to coarse sandstones with mudstones. The former consists of siltstone, mudstone and marl with limestone lenses. Földvary (2000) documented rugose and tabulate corals, brachiopods and stromatoporoids from the Trundle Group and underlying Derriwong Group.

Conodont faunas were reported by Pickett \& McClatchie (1991) from the Trundle Beds (Trundle Group sensu Sherwin 1996) and the Jerula Formation (Jerula Limestone Member of the Gleninga Formation sensu Sherwin 1996 of the equivalent Yarra Yarra Creek Group). These faunas included Pandorinellina exigua philipi (Klapper), Ozarkodina remscheidensis (Ziegler) and Kimognathus alexeii Mashkova. Burrow (2003, 2006) documented fish faunas from limestones of the Trundle region.

Two spot samples from the district were taken to augment the investigation of stratigraphic sections across the vast geographic area of this study. The "Trundle" sample was collected from a locality $10 \mathrm{~km} \mathrm{SSW}$ of Trundle township from a small exposure of limestone, closely equivalent to locality 322 of Földvary (2000). The "Troffs" sample was collected as float from a roadside locality some $13 \mathrm{~km}$ north of Trundle township.

\section{Biostratigraphic synthesis}

The main focus of this study was to establish a broad chronological framework for isolated limestone outcrops over a vast geographical region of New South Wales. All units 

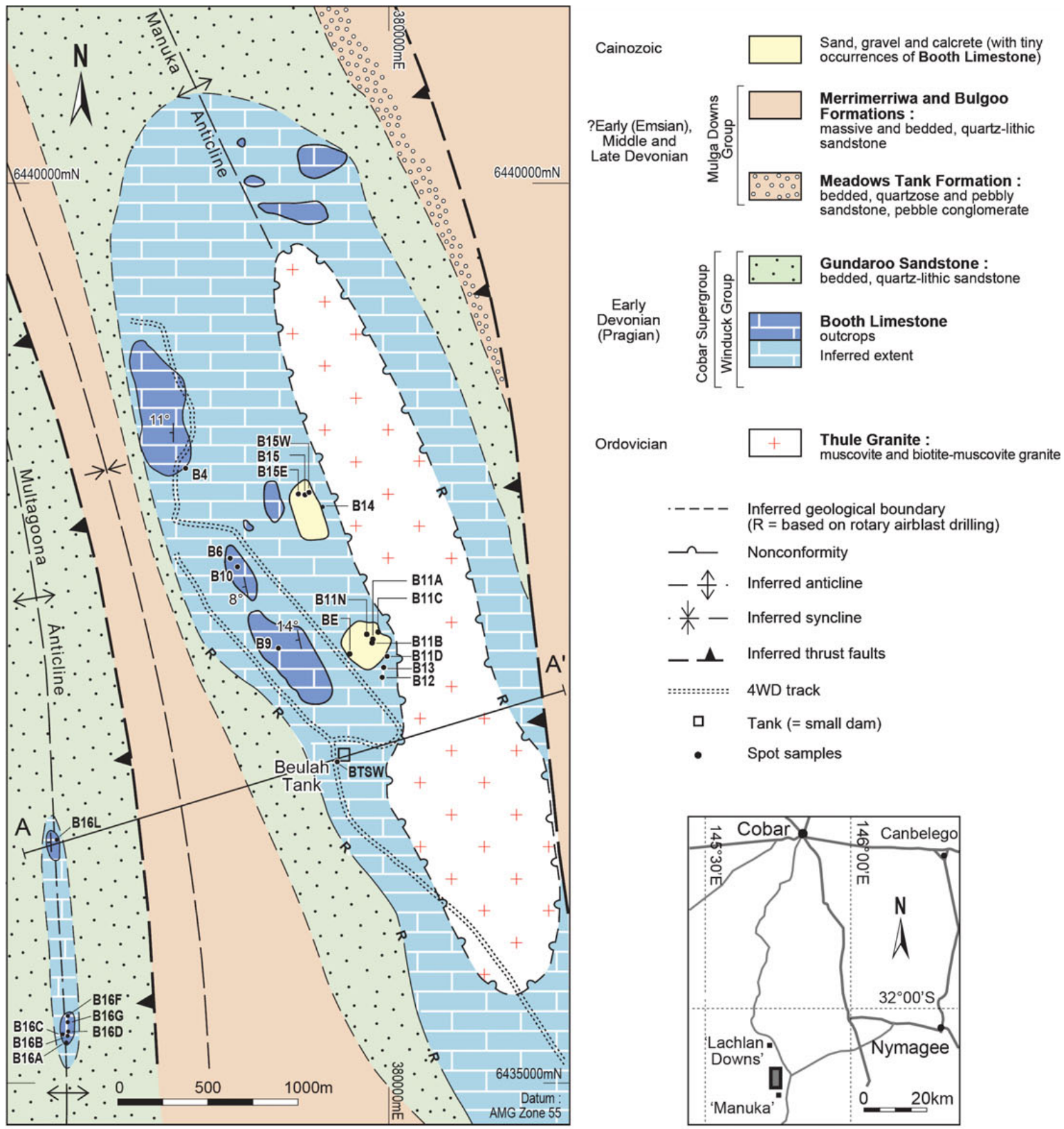

\section{Section A - $A^{\prime}$}

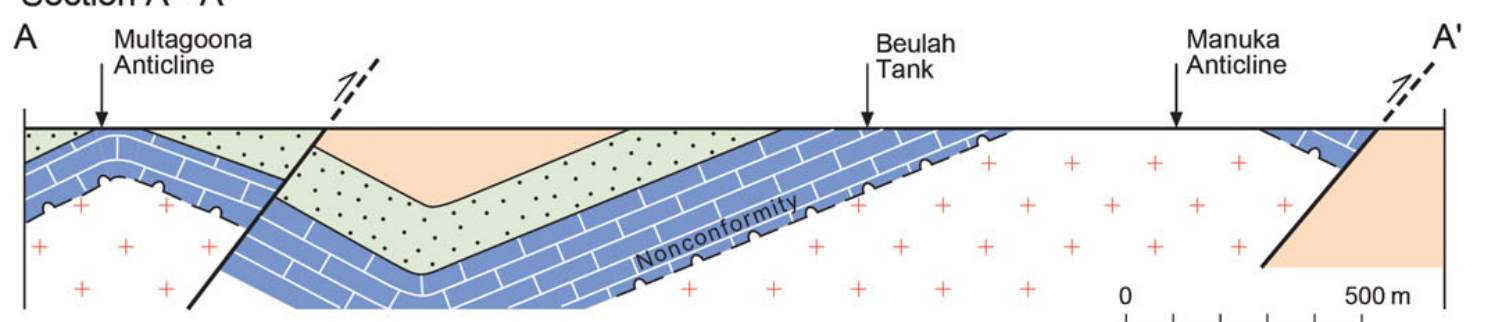

Figure 3. Geology in the vicinity of Beulah Tank on "Manuka" station, based on mapping by Conzinc Rio Tinto Australia, Geopeko, Melissa Hurst and Elizabeth Brand [1994, unpub. B.Sc. (Hons) theses, Melbourne University] and by the authors with sites sampled for conodonts and silicified faunas. Note that portions of the boundaries between the Gundaroo Sandstone and the Booth Limestone, and between the latter and the Thule Granite, are accurate and based on rotary airblast drilling undertaken during mineral exploration. 
Table 1. Table of lattitudes and longitudes of surficial Cobar Supergroup carbonates investigated in this study.

\begin{tabular}{|l|l|l|l|}
\hline & Location & Lithological Unit & Latitude \& Longitude \\
\hline 1 & Beulah Tank & Booth Limestone & $-32^{\circ} 05^{\prime} 06.05^{\prime \prime} \mathrm{S} 145^{\circ} 39^{\prime} 40.88^{\prime \prime} \mathrm{E}$ \\
\hline 2 & 'Marobee' Homestead & Mountain Dam Limestone & $-32^{\circ} 34^{\prime} 53.88^{\prime \prime} \mathrm{S} 146^{\circ} 26^{\prime} 15.05^{\prime \prime} \mathrm{E}$ \\
\hline 3 & Stoney Tank, Mt Gundabooka & Mt Gundabooka Limestone & $-30^{\circ} 38^{\prime} 18.37^{\prime \prime} \mathrm{S} 145^{\circ} 39^{\prime} 48.37^{\prime \prime} \mathrm{E}$ \\
\hline 4 & SE of Nymagee & Beloura Tank Limestone & $-32^{\circ} 12^{\prime} 14.77^{\prime \prime} \mathrm{S} 146^{\circ} 27^{\prime} 20.87^{\prime \prime} \mathrm{E}$ \\
\hline 5 & The Bluff & Lerida Limestone & $-31^{\circ} 46^{\prime} 55.57^{\prime \prime} \mathrm{S} 145^{\circ} 38^{\prime} 8.36^{\prime \prime} \mathrm{E}$ \\
\hline 6 & "The Rookery" Station & White Tank Limestone & $-31^{\circ} 43^{\prime} 32.30^{\prime \prime} \mathrm{S} 146^{\circ} 3^{\prime} 47.60^{\prime \prime} \mathrm{E}$ \\
\hline 7 & "Myola" Station & Limestones of the Derriwong Group & $-32^{\circ} 56^{\prime} 36.81^{\prime \prime} \mathrm{S} 147^{\circ} 41^{\prime} 17.28^{\prime \prime} \mathrm{E}$ \\
\hline 8 & "Trundle" sample & Limestones of the Trundle Group & $-32^{\circ} 59^{\prime} 34.79^{\prime \prime} \mathrm{S} 147^{\circ} 41^{\prime} 18.81^{\prime \prime} \mathrm{E}$ \\
\hline 9 & "Troffs" sample & Limestones of the Trundle Group & $-32^{\circ} 49^{\prime} 1.90^{\prime \prime} \mathrm{S} 147^{\circ} 41^{\prime} 57.41^{\prime \prime} \mathrm{E}$ \\
\hline
\end{tabular}

investigated are Early Devonian in age with the exception of the Silurian (late Ludlow) limestone at Myola.

Conodont zonal schemes in the Lower Devonian have been the subject of much debate. The base of the Pragian was originally defined (Chlupáč \& Oliver 1989) as conincident with the first appearance of the conodont Eognathodus sulcatus Philip as identified by the sulcate morphology of the Pa element. The previous work of Lane \& Ormiston (1979) had established a broad tripartite division of the Pragian based on perceived evolutionary relationships within the genus Eognathodus (the oldest sulcatus and subsequent kindlei zones) and the later appearance of Polygnathus pireneae Boersma (youngest pireneae zone). This global standard was generally accepted as a framework for many subsequent investigations of Pragian conodont faunas around the world.

With more intensive sampling of sequences, growing dissatisfaction with both the positioning of upper and lower Pragian boundaries, and the viability of the conodont zonation have been expressed. Calls for a revision of the global standard scheme for the Pragian (e.g. Slavík et al. 2007) and also parts of the underlying Lochkovian (Valenzuela-Ríos \& Murphy 1997, Valenzuela-Ríos et al. 2015) have been prompted by a combination of new data from European and North American sequences and proposed revisions of conodont systematics.

Nomenclatural revisions have been based on attributing taxonomic significance to single morphological variations from single elements (e.g. Pa element basal cavities; Bardashev et al. 2002) or a combination of features including the nature of sulcate morphologies (e.g. Murphy 2005) as a way of interpreting lineages. Change to taxonomic nomenclature has outpaced detailed apparatus reconstructions. For example, Bardashev et al. (2002) provided a revised interpretation of generic and suprageneric taxonomy that included separating some early eognathodids into a new genus, Gondwania. Some authors have accepted this revised nomenclature despite criticisms of the methodology (e.g. Murphy 2005), while others considered Gondwania a junior synonym of Eognathodus (e.g. Lu et al. 2016).
Globally accepted biostratigraphic concepts should be based only on a sound, globally accepted taxonomy. Much of the taxonomic contention that has impacted Pragian biostratigraphic concepts is centred on alternative interpretations of eognathodid and polygnathodid conodont lineages. Debate about the evolutionary origin of the sulcate morphology includes the recovery of examples from beneath the Pragian base and the identification of an "incipient but not really developed" sulcus (Slavík et al. 2007).

In assessing the biostratigraphic utility of a Lochkovian lineage (Lanea carlsi), Slavík (2011) made the point that some features such as ornament on Pa elements can be a recurrent phenomenon within lineages, and that changes to other elements can be indicative of evolutionary change. Work on reconstruction of key Early Devonian conodont apparatuses and their biostratigraphic application continues.

Well-defined, easily recognisable, relatively abundant, cosmopolitan taxa, as the basis of a global scheme for the Pragian, appear elusive. Our study reports a high number of new taxa. Endemism may mean that a global standard is not possible (Slavík et al. 2007). Meanwhile, regionally based schemes proliferate (e.g. for the Barrandian of central Bohemia - Slavík 2004a; Nevada - Murphy 2005), as does discussion on the appropriate lower boundaries of the Early Devonian series (e.g. Pragian - Slavík 2004a, Valezuela-Ríos et al. 2005; Emsian - Yolkin et al. 1997, Carls et al. 2008) and even on the viability of a Devonian standard conodont zonation (Bultynck 2007).

As an illustration of the current uncertainties, Becker et al. (2012, fig. 22.13) in their synthesis provided two biostratigraphic versions for the Pragian, namely the historically established tripartite standard zonation as currently accepted by the Subcommission on Devonian Stratigraphy and an alternative zonation based on more recent regional work. In the alternative zonation (Becker et al. 2012, fig. 22.10), no zonal boundary aligns with the commencement of the Pragian. The Gondwania irregularis Zone spans the latest Lochkovian and earliest Pragian, 
A
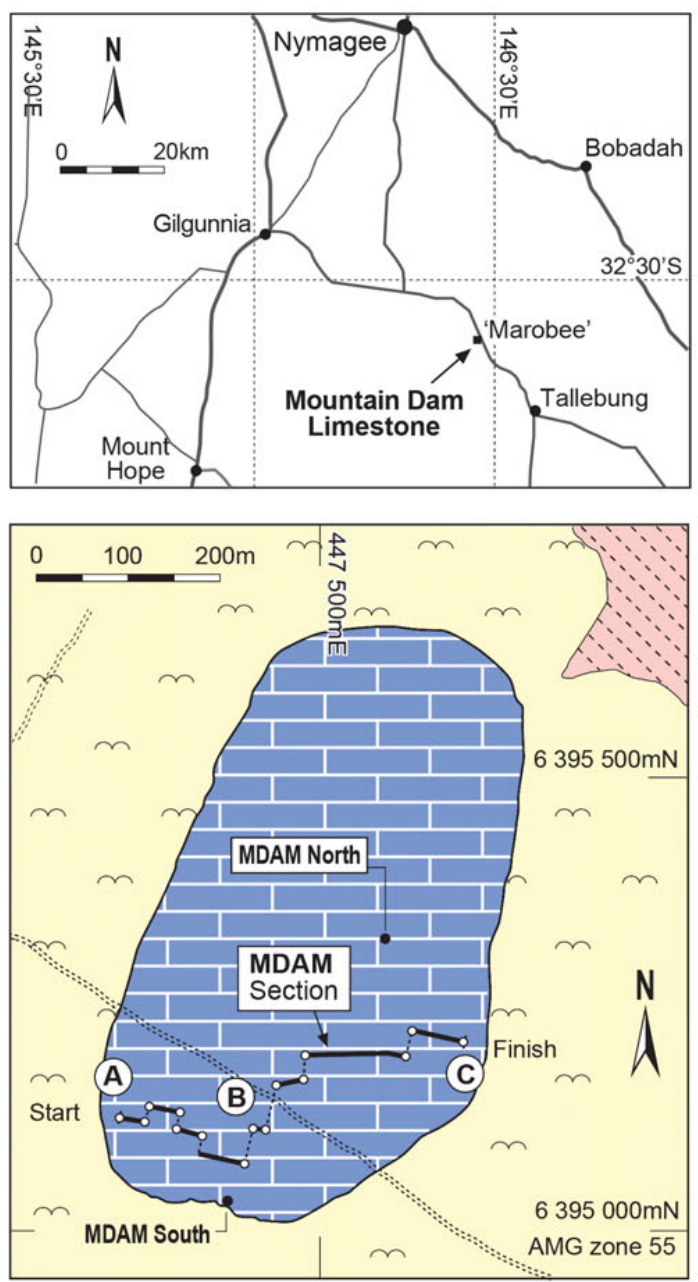

MDAM Section
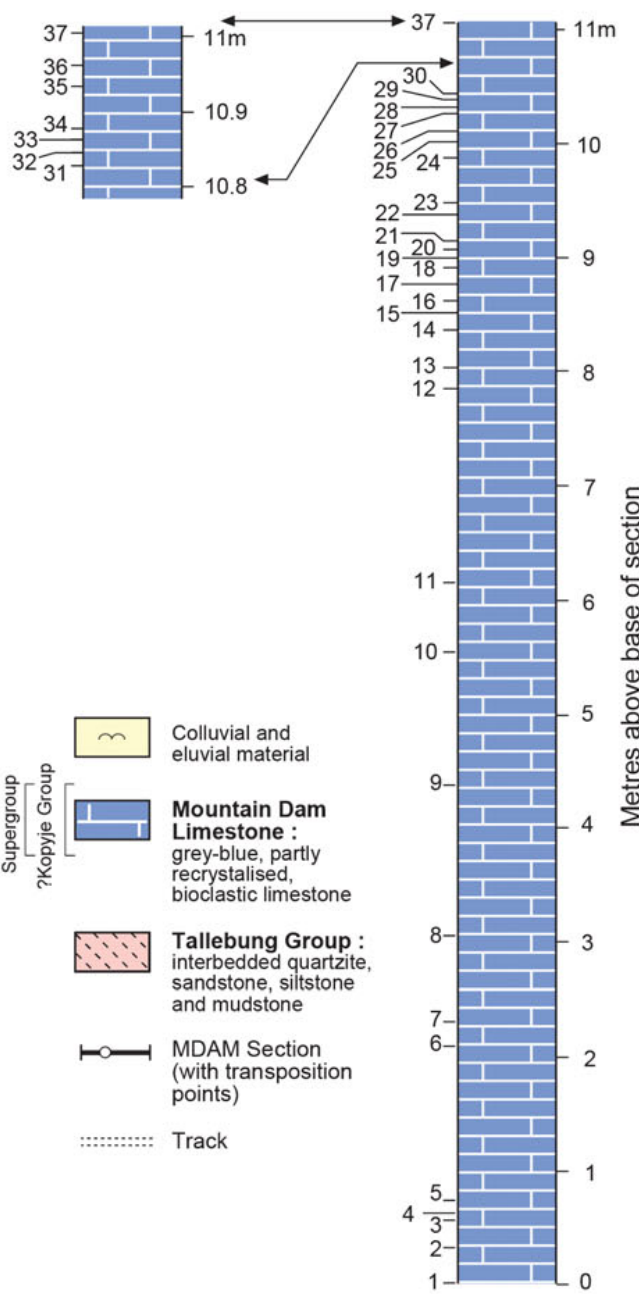

B

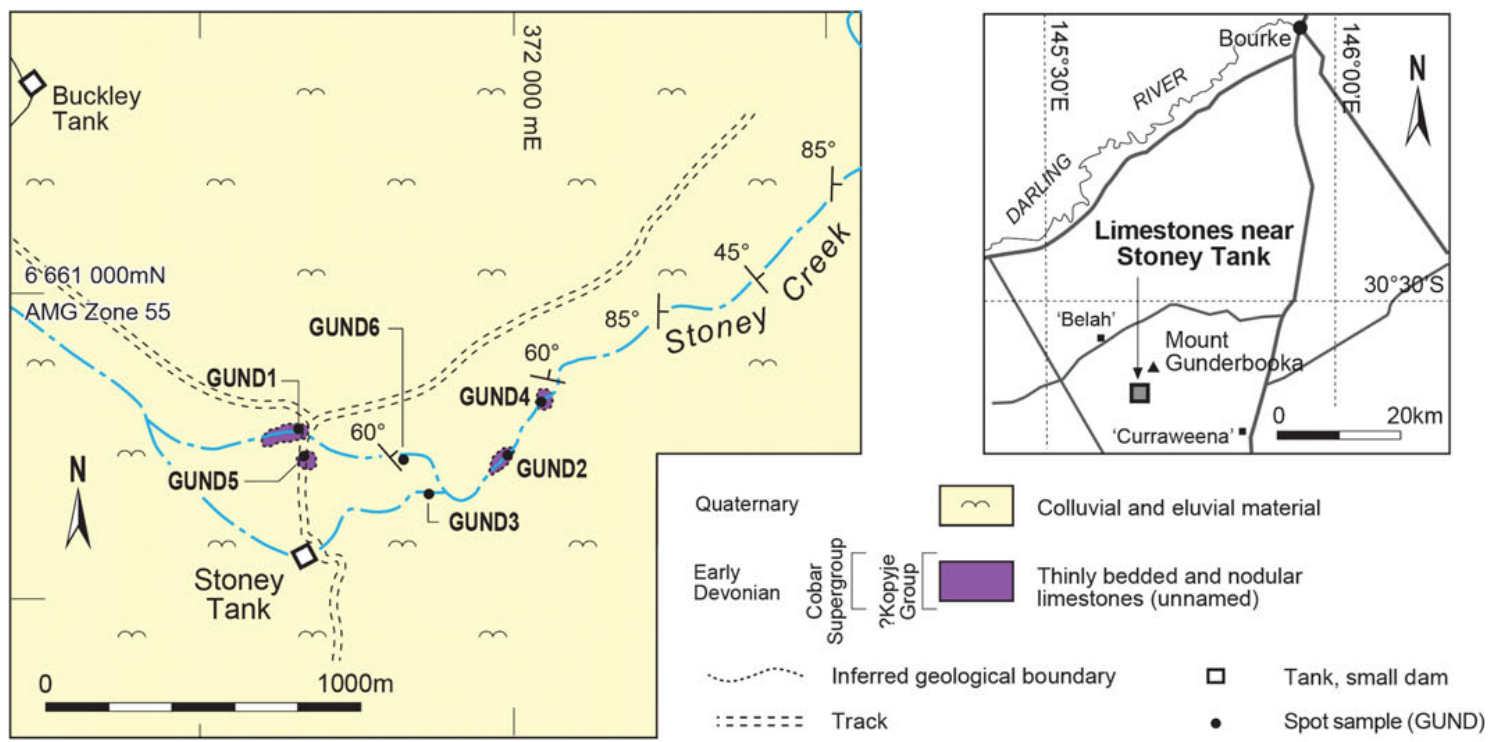

Figure 4. Location maps. $\bullet$ A - position of composite stratigraphic section sampled through the Mountain Dam Limestone and stratigraphic column derived from amalgamating field data. $\bullet$ B - location of sampled limestones in Stoney Creek, north of Stoney Tank in the Gunderbooka National Park. 
preceeding the subsequent Gondwania kindlei Zone that appears broadly aligned with the kindlei Zone in the standard zonation. Slavík et al. (2007), however, argued that, based on Barrandian sections, the kindlei Zone is broadly penecontemporaneous with the preceeding sulcatus Zone, implying neither should be considered as definitively Pragian in age.

In Australia, progress on the documentation and analysis of Early Devonian conodont sequences has been summarised at various intervals (Mawson et al. 1988, 1992; Mawson \& Talent 2000). The most extensively developed Pragian carbonate sequences are found in the southern regions of the Tasman Fold Belt. Philip (1965) first defined the genus Eognathodus from the Coopers Creek Formation in Victoria. Mawson \& Talent (1994) documented conodonts from an extensive area including allochthonous units in the Walhalla Synclinorium, and indicated an age-range from the sulcatus Zone through the kindlei Zone to the early Emsian dehiscens Zone.

Druce (1971) first recovered an eognathodid from the Garra Limestone in New South Wales. Subsequent sequentially sampled sections have led others to conclude that the formation spans the Lochkovian-Pragian boundary. At Wellington it spans the pesavis to pireneaeldehiscens zones (Wilson 1989), at Eurimbla it spans the delta to sulcatus zones (Sorentino 1989). At the Gap, it was also interpreted as spanning the delta to sulcatus zones (Farrell 2003). Elsewhere in the Tasman Fold Belt, the Cavan Formation is interpreted as extending from the pireneae Zone to the dehiscens Zone (Mawson et al. 1992). Conodonts obtained from extensive debris flows, shed from the Molong High, indicate ages ranging from the pesavis to dehiscens zones (Talent \& Mawson 1999). Pragian faunas have been reported in the Tamworth region (Dongol 1995) and the Ilford region (Colquhoun 1995). They are also known from the Point Hibbs Formation in Tasmania (Winchester-Seeto \& Carey 2000) and the Shield Creek Formation, Broken River Province, north Queensland (Jeppsson et al. 2007, fig. 3).

No distinctive, regional Early Devonian conodont zonation has emerged in Australia; authors have endeavoured to work within the frame of the global standard. In Europe, a lack of eognathodids has hampered correlations; Slavík et al. (2007) have expressed a preference for working with Icriodus and Pelekysgnathus. Despite the documentation herein of representatives of these genera, they are in general relatively poorly represented in Australian faunas prior to the late Emsian, as noted by Talent $e t$ al. (2000).

In the present study, the provincial nature of Pragian faunas is emphasised by the number of new taxa documented. However, we also propose a new interpretation of the evolution of Eognathodus through a closer analysis of basal cavity shapes in Pa elements. We note that the possi- bility of a polymorphic origin for the sulcate eognathid $\mathrm{Pa}$ element morphology suggests a lack of global heterochroneity for this morphological innovation and makes for an unreliable marker at the base of a geological series. We also document the new species Icriodus ampliatus and interpret it as late sulcatus Zone in age.

As noted above the intention of this study was to establish a broad chronological alignment for widely dispersed, isolated carbonate units. None of the units investigated span any more than a single conodont zone with the possible exception of the Booth Limestone. In the absence of a regional zonal scheme for the Early Devonian in Australia and faunal differences from European and North American sequences, we report our findings in terms of the currently accepted global standard zonation. We do this without prejudice, realising that further work on Pragian conodont faunas in Australia and elsewhere may lead to reconsideration of series boundaries and the architecture of biostratigraphic zonations.

\section{Implications of conodont data}

\section{Booth Limestone}

As noted above, the Booth Limestone crops out in two anticlines (Fig. 3): the Manuka Anticline to the east and the Multagoona Anticline to the west. Conodonts from the easternmost limestone horizons of the Manuka Anticline, closest stratigraphically to the nonconformity between the Thule Granite and the Booth Limestone, are indicative of an age late in the sulcatus Zone. This opinion is based on the occurrence of Icriodus ampliatus sp. nov., but from horizon $\mathrm{B} 9$ the fauna changes dramatically with the incoming of Ozarkodina buchanensis (Philip) and Pandorinellina exigua philipi (Klapper), forms that occur together in faunas dated as pireneae Zone (Mawson et al. 1992) - the still inadequately defined last interval (or intervals) of the Pragian - at Boulder Flat in eastern Victoria.

The Booth Limestone cropping out in the Multagoona Anticline has a similar fauna to the uppermost Booth Limestone in the Manuka Anticline but with the addition of Oulodus astriatus sp. nov. and Oul. paucistriatus Mawson, the latter described from the Lilydale Limestone of Victoria, a sequence that commences in the kindlei Zone but for the most part is "pireneae Zone" or conceivably younger in age (Wall et al. 1995). Two specimens from B 16L, the westernmost outcrop, are compared with Pandorinellina exigua exigua (Philip). If this identification can be confirmed with further sampling, it would indicate that the uppermost Booth Limestone extends into the dehiscens Zone and thus into the earliest Emsian, defined by the entry of Polygnathus dehiscens (Philip \& Jackson) as approved by the International Commission on Stratigraphy (see Yolkin 
A
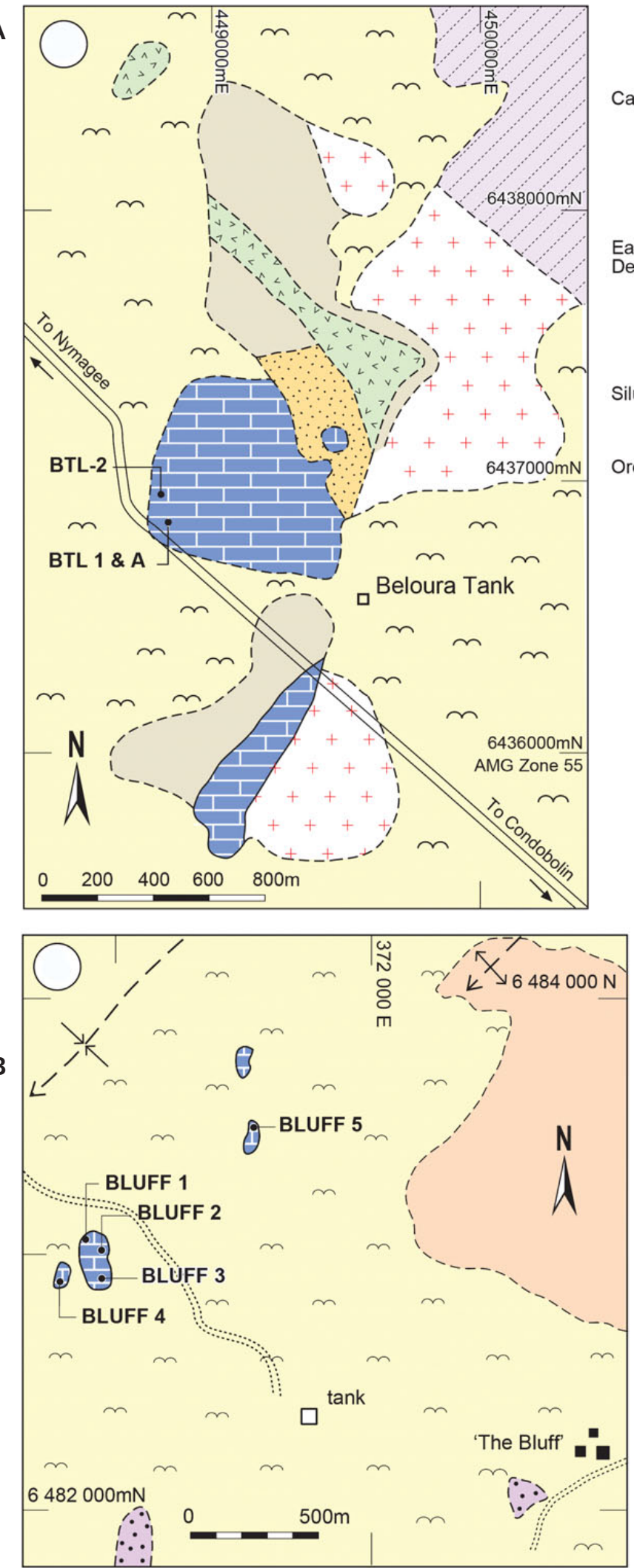

Cainozoic

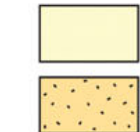

Colluvial and eluvial material

Sandstone to granule conglomerate
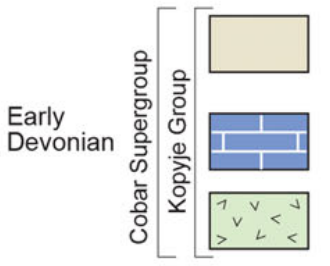

Baledmund Formation :

laminated and massive siltstone and minor sandstone

Silurian

Ordovician

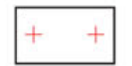

Beloura Tank Limestone Member

Hennings Tank Tuff Member : rhyolite vitric tuff, minor bedded crystal tuff

Erimeran Granite :

porphyritic, massive, granite and

Girilambone Group :

quartz-mica schist, quartzite
sandstone and siltstone

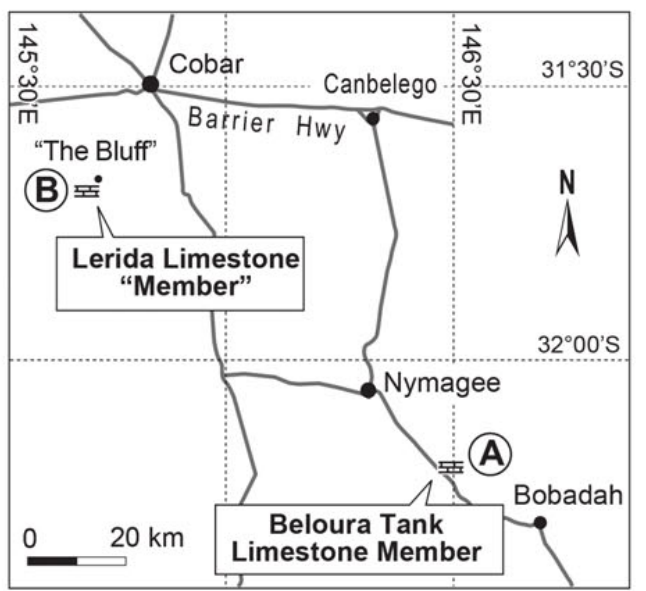

$\begin{array}{lll}n \text { Quaternary } & \text { Alluvial gravel, sand, silt and clay }\end{array}$

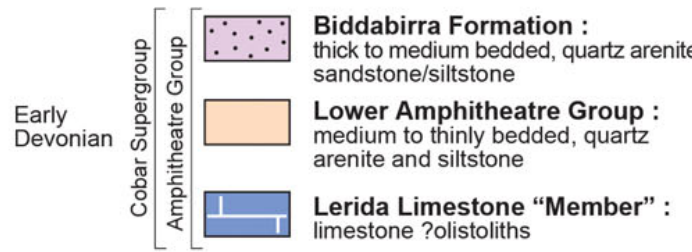

$\begin{array}{llll}\text { Geological boundary } & \text { ::::::: } & \text { Track } \\ \leftarrow \text { Inferred geological } & \text { - } & \text { Buildings } \\ \text { boundary } & \square & \text { Tank or small dam } \\ <\uparrow-\text { Inferred syncline } & \text { Inferred anticline } & \text { - Spot samples }\end{array}$

Figure 5. Location maps. $\bullet$ A - geology in the vicinity of Beloura Tank showing location of samples acid-leached from the Beloura Tank Limestone Member of the Baledmund Formation. • B - geology in the vicinity of the four ?olistoliths of limestone on which the "Lerida Limestone Member" of the lower Amphitheatre Group on "The Bluff” station was based (Glen 1987), and location of sample. 


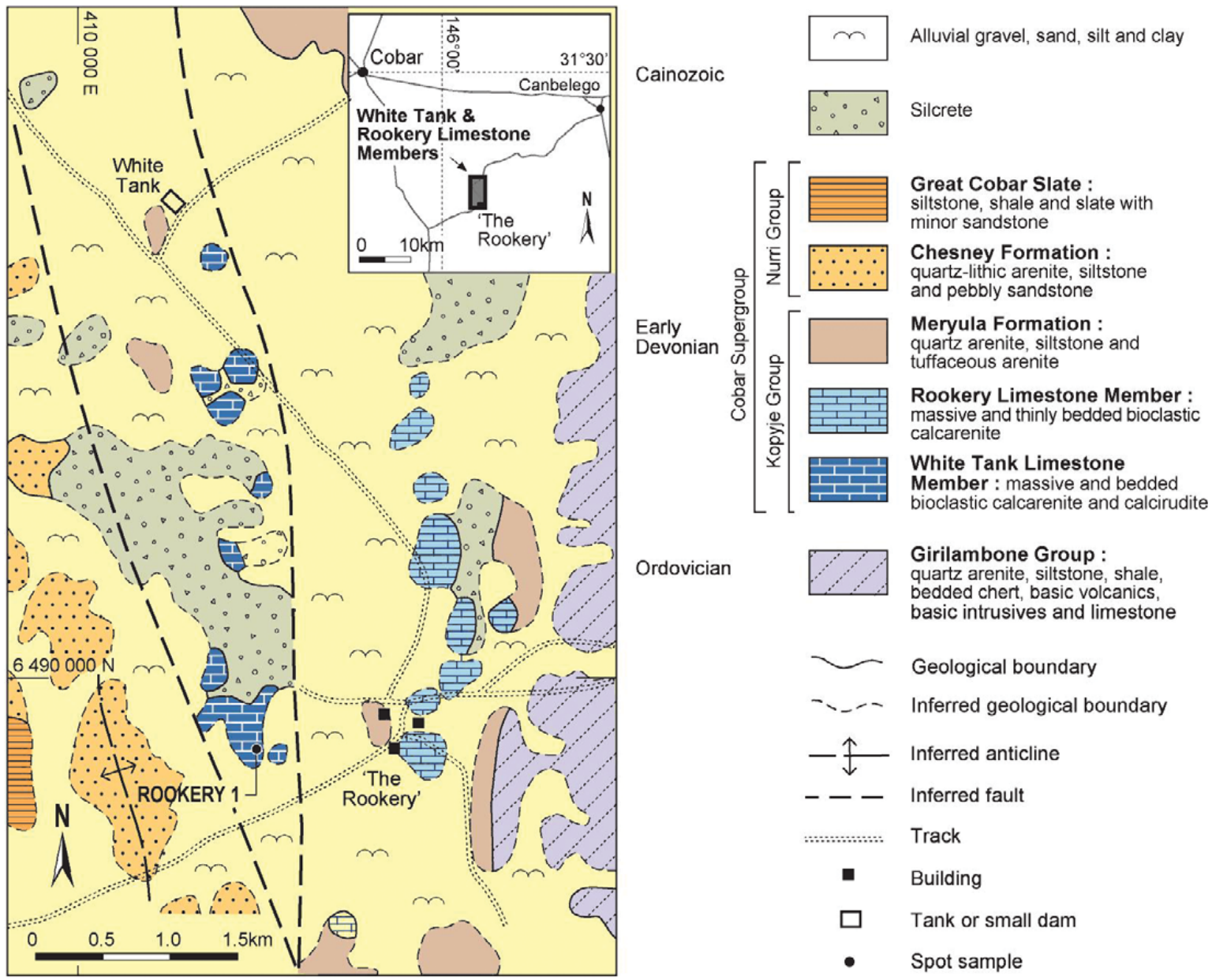

Figure 6. Geology in the vicinity of "The Rookery" homestead showing distribution of outcrops allocated to the White Tank and Rookery limestone members of the Meryula Formation (from Pickett 1980) and location of the only sample acid-leached in this investigation.

et al. 1997, 2000) and not rescinded. Polygnatus dehiscens is an especially well characterised, valid, and biostratigraphically useful species, contra confusing attempts to sideline it in favour of various forms proposed subsequently (Mawson 1998) and questionable taxonomic procedures with polygnathid conodonts (Bardashev et al. 2002; cf. Mawson \& Talent 2003).

\section{Mountain Dam Limestone}

The $11 \mathrm{~m}$ section sampled for this study (Fig. 4A, Table 2) yielded over 1500 conodont elements. Eognathodus sulcatus lanei subsp. nov. and Eo. sulcatus sicatus subsp. nov. are present from the base to the top of the section, from MDAM 1 to MDAM 37; consequently, the entire section can be dated broadly as sulcatus Zone. In the uppermost sample, MDAM 37, however, the occurrence of Icriodus ampliatus sp. nov. with $I$. sp. cf. I. celtibericus suggests this level at least represents the topmost part of the sulcatus Zone.

\section{Stoney Creek limestones, Gunderbooka National Park}

The presence of Ozarkodina buchanensis (Philip) and $O z$. sp. cf. Oz. buchanensis in three of the GUND samples (Table 3) together with species such as Panderodus exigua philipi (Klapper) and Pand. steinhornensis miae (Bultynck) indicates a late Pragian age ("pireneae Zone") attribution for these spot samples, an age that aligns with the upper Booth Limestone.

\section{Beloura Tank Limestone Member}

The two productive samples from the Beloura Tank Limestone Member, like those from the Stoney Creek limestones, show a fauna composed predominantly of simple cones (Table 3). This, with the occurrence of Oulodus sp. cf. walliseri and Icriodus angustoides angustoides Carls \& Gandl, forms common to the ?olistoliths of the Mountain Dam Lime- 

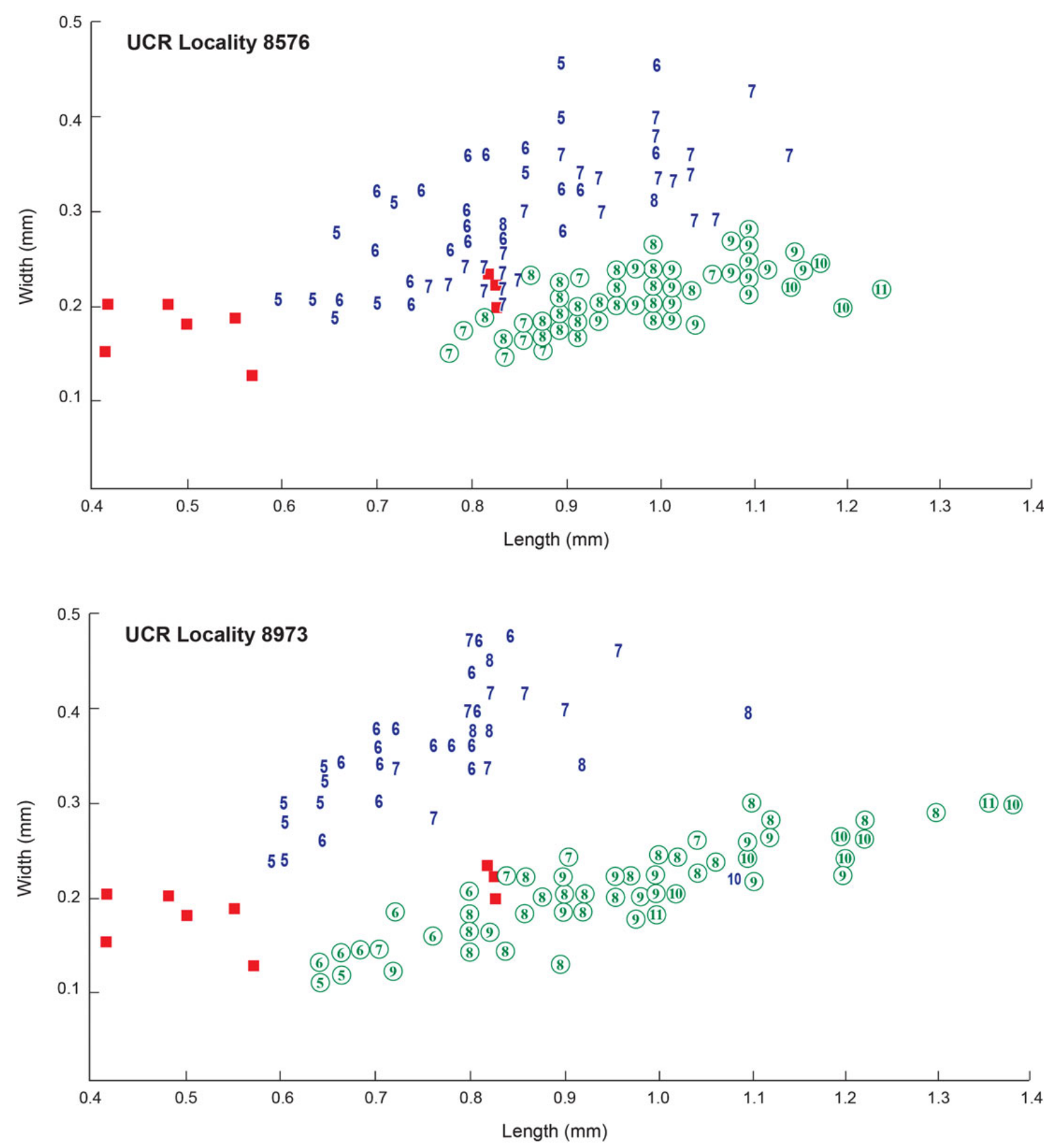

Figure 7. Scatter diagram (after Murphy \& Cebecioğlu 1984) with width vs length of Icriodus claudiae (green circles) and I. steinachensis (blue numbers without circles) from two University of California Riverside localities (UCR 8576 and 8973) in central Nevada, and I. ampliatus (solid red squares) from the Booth and Mountain Dam limestones of western New South Wales. Note that, although generally smaller in size, the new species I ampliatus plots between I. claudiae and I. steinachensis.

stone and "Lerida Limestone Member", accords with these samples being referred - broadly - to the sulcatus Zone.

\section{"Lerida Limestone Member"}

The composition of the conodont faunas of the five samples of Lerida Limestone (Table 3 ) is very similar to those from the Mountain Dam Limestone section with a large proportion of the elements identified as simple cones. There is a dearth of icriodids and oulodids as was noted for the faunas from the Rookery Limestone Member. The occurrence of subspecies of $\mathrm{Oz}$. selfi Lane \& Ormiston in two of the samples accords with attribution of these ?olistoliths of the "Lerida Limestone Member" to the sulcatus Zone. 


\section{White Tank and Rookery limestone members of the Meryula Formation on "The Rookery" station}

The age of the Rookery Limestone Member has been based on Pickett's (1980) argument that a species of Pedavis from a sample bore core (MAL1, $215 \mathrm{~m}$ ) put down on "The Rookery" station is Ped. pesavis (Bischoff \& Sanneman). In the past 25 years, many papers have been written concerning the discovery and identification of new species of Pedavis; it is now clear that the one Rookery Limestone specimen illustrated as Ped. pesavis by Pickett (1980, text-fig. 4E) is a younger species. Specific assignment is somewhat problematic, but compared to Ped. pesavis (sensu stricto), the curvature of the posterior process is not as pronounced and the angle at which the lateral processes subtend the anterior process is much greater in the specimen he illustrated. The rest of the Rookery fauna is very similar to that from the first $10.95 \mathrm{~m}$ of the Mountain Dam Limestone: neither includes icriodids, and both have only a smattering of oulodids. The Rookery Limestone Member, however, has a greater proportion of Amydrotaxis druceana (Pickett) than faunas from the Mountain Dam Limestone and has no eognathodontans or subspecies of Ozarkodina selfi Lane \& Ormiston. Facies differences presumably account for this.

Icriodus woschmidti Ziegler was reported from the White Tank Limestone by Pickett (1980, fig. 3A-D) but the species is reinterpreted herein as Icriodus ampliatus sp. nov. Specimens illustrated as Ozarkodina cf. eurekaensis Klapper \& Murphy by Pickett (1980, fig. 8A-M) are reinterpreted variously as a subspecies of Eognathodus sulcatus Philip and subspecies of Ozarkodina selfi Lane \& Ormiston (see relevant species and subspecies in the systematics below). The White Tank Limestone is dated as upper sulcatus Zone in age.

\section{Myola Limestone}

The seven samples collected can all be ascribed a late Silurian age. More specifically, the samples Myola 0, 1 and 4 are latest Ludlow crispa Zone in age due to the occurrence of the index species. Strata of this age were previously reported in the Trundle region by Pickett \& Ingpen (1990), and are known elsewhere in southeastern Australia in the Yarrangobilly Limestone (Cooper 1977) and in the Cowombat Formation at Cowombat Flat (Simpson et al. 1993). Simpson (1995) revised the age of other Australian sequences through the late Ludlow to Přídolí interval based on a reinterpretation of previously published conodont data, macrofossil evidence and stratigraphic alignments.

The associated fauna in all the Myola samples is very similar and supports this age interpretation. Ozarkodina confluens (Branson \& Mehl) occurs in Myola 0, 2, 3 and 4. This is a cosmopolitan conodont species with a highly variable Pa element known to range from the Ludlow siluricus Zone, through the late Ludlow crispa Zone and high into the Přídolí. The Pa elements of this taxon recovered from Myola are closest in morphology to the alpha morphotype of Klapper \& Murphy (1975), and virtually identical to those recovered from crispa Zone faunas at Yarrangobilly and Cowombat.

Pelekysgnathus? sp. A was recovered in the samples Myola 2, 4 and 6. In Sardinia this taxon is restricted to the lower part of the crispa Zone (Corriga \& Corradini 2009). It is different from the Nevada taxon $P$. index Klapper \& Murphy which was recognized as extending through the crispa Zone and into overlying Přídolí strata and was the basis of an informal early Př́idolí biostratigraphic interval (P. index fauna of Klapper \& Murphy 1975). The species recovered in this study is poorly known but it is possible that it occupies a similar biostratigraphic range in Australia.

Coryssognathus dubius (Rhodes) is a Silurian species previously interpreted as having an uppermost range within the Ludlow (Simpson 1995), but Corradini \& Serpagli (1999) reported occurrences high in the Přídolí (detortus Zone). The species was recovered in Myola 0, 1, 2, 5 and 6, and was previously reported in Australia in the Yass Basin (Link \& Druce 1972), the Kildrummie Formation (De Deckker 1976), the Trundle region (Pickett \& Ingpen 1990), the Murda Syncline (Pickett \& McClatchie 1991), Cowombat (Simpson et al. 1993), the Claire Creek-Stoney Creek area (a different Stoney Creek some $850 \mathrm{kms}$ SSE of Gundabooka National Park) and Native Dog Plain in the Cowombat region (Simpson \& Talent 1995), Broken River region (Sloan et al. 1995, Talent et al. 2002), the Borenore Formation (Cockle 1999) and the Cobra Formation (Valentine et al. 2006). It has also been reported from numerous localities internationally.

Whilst it is likely that all the localities sampled are latest Ludlow in age, one sample, Myola 2, has a single Sb element tentatively identified as Oulodus elegans detorta? (Walliser) because of the alternating denticulation on the partially preserved processes. This taxon has previously been associated with the late Přídolí (Jeppsson 1988). Carls et al. (2007), however, outlined a detailed biostratigraphic argument that this could represent a miscorrelation of an older interval, and if so this supports the contention that all samples from Myola were taken along strike and are age-equivalent. The Myola 2 sample has not yielded Ozarkodina crispa (Walliser), but its associated conodont fauna is similar to other Myola samples.

Two samples, Myola 2 and 6, contained unusual elements tentatively identified as Erika divarica Murphy \& Matti. This taxon, originally based on Early Devonian material from Nevada (Murphy \& Matti 1982), is poorly known. Miller \& Märss (1999) described some robust ele- 
ments from the lower Přídolí Downton Castle Sandstone and, although noting some of their similarities to $E$. divarica, reconstructed them as Ozarkodina? hemensis.

Our study reveals a slightly more diverse conodont fauna in the Myola Limestone than previously reported and concurs with Pickett \& Ingpen's (1990) original age determination.

\section{"Trundle" and "Troffs" samples}

Samples from Troffs yielded Ozarkodina remscheidensis remscheidensis (Ziegler) and Pandorinellina exigua philipi (Klapper). The incoming of the latter is considered to be indicative of the pireneae Zone.

The Trundle sample also has Oz. rem. remscheidensis but is much more diverse and includes the taxa Ozarkodina paucidentata Murphy \& Matti (emended herein), Ozarkodina excavata excavata (Branson \& Mehl) and Eognathodus sulcatus lanei subsp. nov., all of which indicate a broad sulcatus Zone age. The presence of Icriodus ampliatus sp. nov., as in the Mountain Dam Limestone, suggests the topmost part of the sulcatus Zone may be present.

\section{Comments on Colour Alteration Indices of conodont fauna}

Colour Alteration Indices data from conodonts has been used as a proxy for thermal maturity. This technique has not been widely applied in the Lachlan Fold Belt, although Brime et al. (2003) compiled extensive CAI data with illite crystallinity data from the Townsville hinterland, in the northern part of the Tasman Orogen.

Earlier reconnaissance reports of conodont faunas from the Darling Basin by the Geological Survey of New South Wales suggested the possibility of low thermal maturity and of oil and gas prospectivity at some locations. A corpus of new CAI and illite crystallinity data was accumulated over the period of our investigation. It indicates that thermal maturity is highly variable over the extensive geographic range of the Darling Basin. These data, which will be documented in detail elsewhere, build on earlier prospectivity studies (Brown et al. 1982, Stewart \& Alder 1995, Alder et al. 1998, Cooney \& Mantaring 2007) and facies analysis (e.g. Khalifa 2005, Khalifa et al. 2015) of the Darling Basin.

\section{Systematic palaeontology}

Discussion of conodonts is restricted to genera, species and subspecies that are new or of particular stratigraphic or taxonomic interest. Other conodont taxa have been identified
(Tables 2, 3), briefly commented on, and are illustrated in Figs 8 to 32. The classification of conodonts used herein follows Sweet (1988). Type and figured specimens are deposited in the microfossil collection of the Geological Survey of New South Wales (MMMC), housed at the W.B. Clarke Geoscience Centre at Londonderry (outer western Sydney).

Abbreviations. - The following abbreviations are used for conodont genera throughout the text, on figures and in the distribution charts: Amy. - Amydrotaxis; Anc. - Ancyrodelloides; B. - Belodella; E-Erika; Eo. - Eognathodus; I. - Icriodus; H. - Heliagnathus; Oul. - Oulodus; Oz. - Ozarkodina; Pand. - Panderodus; P. - Pandorinellina; Pel. - Pelekysgnathus; Ps. - Pseudooneotodus.

Abbreviations used for stratigraphic sections and as prefixes for sample numbers are: MDAM - Mountain Dam Limestone; B - Booth Limestone; BLUFF - samples collected in the "Lerida Limestone Member"; GUND - samples collected in stratigraphic order near Stoney Tank, Gunderbooka National Park; BTL - spot samples from the Beloura Tank Limestone Member in the vicinity of Beloura Tank.

Order Protopanderontida Sweet, 1988

Family Protopanderodontidae Lindström, 1970

\section{Genus Pseudooneotodus Drygant, 1974}

Type species. - Oneotodus? beckmanni Bischoff \& Sannemann, 1958.

Remarks. - Corradini (2008) discussed the history of taxonomic concepts for this genus, including the multi-element reconstructions of Barrick (1977), and concluded on the basis of the stratigraphic distribution of elements that the apparatus was unimembrate. Elements recovered in our study provide no taxonomic insights into this question.

\section{Pseudooneotodus beckmanni \\ (Bischoff \& Sannemann, 1958) \\ Figure 8Q-S}

1958 Oneotodus? beckmanni n. sp.; Bischoff \& Sannemann, p. 98, pl. 5, figs 22-25.

1966 Gen. et sp. indet. A; Philip, p. 113, pl. 8, figs 1-4. For further synonymy to 1984 see:

1985 Pseudooneotodus beckmanni (Bischoff \& Sannemann). - Wang, p. 159, pl. 1, fig. 19. For synonymy to 1990 see:

1990 Pseudooneotodus beckmanni (Bischoff \& Sannemann). - Uyeno, pp. 99-100, pl. 1, figs 22-25. 
1994 Pseudooneotodus beckmanni (Bischoff \& Sannemann). - Mawson \& Talent, fig. 15J-L.

1995 Pseudooneotodus beckmanni (Bischoff \& Sannemann). - Furey-Greig, pl. 1, fig. 3.

1999 Pseudooneotodus beckmanni (Bischoff \& Sannemann). - Cockle, p. 119, pl. 1, figs 1, 2.

1999 Pseudooneotodus beckmanni (Bischoff \& Sannemann). - Talent \& Mawson, pl. 13, figs 1-7.

2000 Pseudooneotodus beckmanni (Bischoff \& Sannemann). - Furey-Greig, p. 139, fig. 6.11.

2000a Pseudooneotodus beckmanni (Bischoff \& Sannemann). - Göncüoğlu \& Kozur, figs 5.3, 5.5-5.7, 6.9, 6.10, 7.2, 8.5.

2000b Pseudooneotodus beckmanni (Bischoff \& Sannemann). - Göncüoğlu \& Kozur, fig. 5.2, 5.5.

2003 Pseudooneotodus beckmanni (Bischoff \& Sannemann). - Mawson et al., pl. 5, figs 13, 14.

2003 Pseudooneotodus beckmanni (Bischoff \& Sannemann). - Pyle \& Barnes, fig. 17.24, 17.25.

2004 Pseudooneotodus beckmanni (Bischoff \& Sannemann). - Farrell, p. 956-957, pl. 2, figs 15-17.

2007 Pseudooneotodus beckmanni (Bischoff \& Sannemann). - Suttner, pp. 18-19, pl. 6, figs 16, 17; pl. 7, figs $1-4$.

2008 Pseudooneotodus beckmanni (Bischoff \& Sannemann). - Corradini, pp. 142-143, pl. 1, figs 1-7 (with extensive synomymy).

2008 Pseudooneotodus (?) beckmanni (Bischoff \& Sannemann). - Eikhvald, p. 251, pl. 2, figs 3-6.

2009 Pseudooneotodus beckmanni (Bischoff \& Sannemann). - Kleffner et al., pl. 1, fig. 13.

2009 Pseudooneotodus beckmanni (Bischoff \& Sannemann). - Berkyová, fig. 10A-D.

2010 Pseudooneotodus beckmanni (Bischoff \& Sannemann). - Wang \& Aldridge, pp. 32-33, pl. 2, figs 19-26.

2010 Pseudooneotodus beckmanni (Bischoff \& Sannemann). - Corradini \& Corriga, pl. 1, fig. 21.

2011 Pseudooneotodus beckmanni (Bischoff \& Sannemann). - Corriga et al., fig. 5.12.

2012 Pseudooneotodus beckmanni (Bischoff \& Sannemann). - Corriga et al., fig. 5.4.

2012 Pseudooneotodus beckmanni (Bischoff \& Sannemann). - Slavík \& Carls, fig. 3U, DD.

2013 Pseudooneotodus beckmanni (Bischoff \& Sannemann). - Wang, p. 60, pl. 2, figs 19-26; pl. 62, figs 8,9 .

2014 Pseudooneotodus beckmanni (Bischoff \& Sannemann). - Corriga et al., fig. 5K, L.

Remarks. - According to Barrick (1977), the apparatus of Pseudooneotodus, specifically Ps. beckmanni, is possibly made up of two elements: a slender form and a squat form. Barrick based his suggestion on the work of Jentzsch
(1962) who observed both forms in Early Devonian horizons in Thuringia. Both forms have a single apical denticle and commonly occur elsewhere in horizons also of Early Devonian age. Specimens encountered in our study are the squat form.

Specimens of Ps. beckmanni illustrated from the TAN section in the lower Cunningham Formation on the western flank of the Hill End Trough (Talent \& Mawson 1999) occur low in the section below the incoming of Icriodus steinachensis eta morph and Pedavis marianneae. As Talent \& Mawson (1999) used these two species to date the section "to be most likely kindlei Zone", there remains the possibility that the lower part of the TAN section may be of late sulcatus Zone age.

Corradini (2008, fig. 2) noted that in Italian collections this species is rare prior to the Ludfordian, then is present through to the Early Devonian and is found in large numbers in the Pragian.

Family Panderodontidae Lindström, 1970

\section{Genus Panderodus Ethington, 1959}

Type species. - Paltodus unicostatus Branson \& Mehl, 1933.

Remarks. - Simpson \& Talent (1995, p. 114) discussed some of the taxonomic history of the genus. Smith et al. (1987) compared a number of reconstructions of the apparatus, for example those given by Bergström \& Sweet (1966), Cooper (1975) and Barrick (1977). More recently, Wang \& Aldridge (2010, pp. 34-36) discussed the genus including varying opinions concerning the presence of a tortiform element in the apparatus of some species. The scheme proposed by Barrick (1977) with Sa, Sb, Sc and M elements plus a tortiform element suggested by Sweet (1979) is used herein. We refer to the tortiform element as the T element. We identify two new species, one based on distinctive cone morphology and the other on the distinct shape of the basal cavity. The latter is kept in open nomenclature because of the small number of specimens obtained.

\section{Panderodus recurvatus (Rhodes 1953)}

Figure 8I-M

1953 Paltodus recurvatus n. sp. Rhodes; p. 297, pl. 23, figs 219, 220.

1995 Panderodus recurvatus (Rhodes). - Simpson \& Talent, pp. 117-118, pl. 1, figs 21-27 (see for further synonymy).

1995 Panderodus recurvatus (Rhodes). - Furey-Greig, pl. 1, figs 14, 15 . 


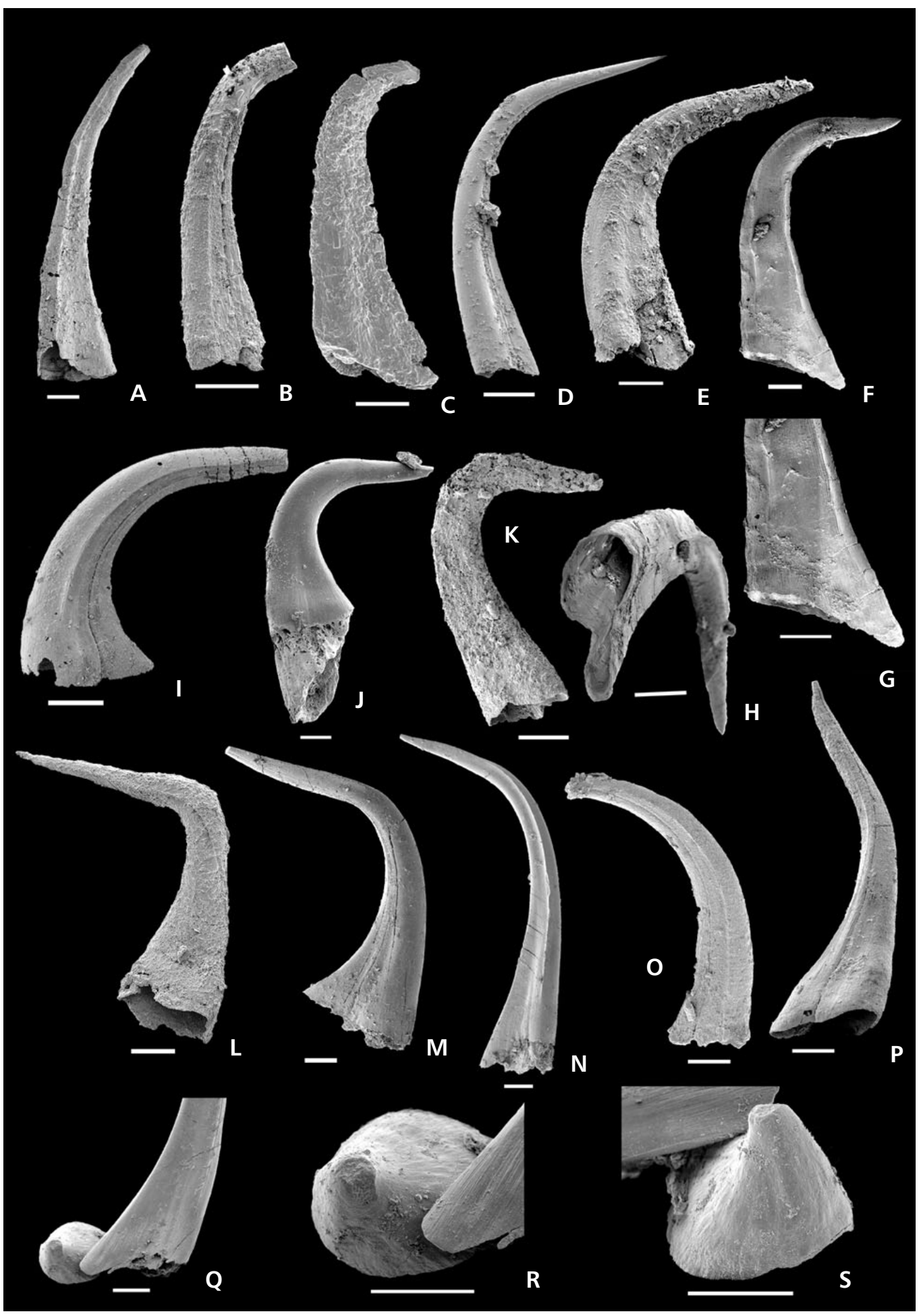

Figure 8. A-E, N-P - Panderodus unicostatus (Branson \& Mehl, 1933). A, B, N, lateral views of Sa elements; A - MMMC 4423 from MDAM 35; B - MMMC 4424 from MDAM 26; N - MMMC 4425 from B 15W. $•$ C, D-- lateral views of Sb elements; C - MMMC 4426 from B 11B; D - MMMC 4427 from MDAM 4. $\bullet$ E - lateral view of M element MMMC 4429 from MDAM 37. • O - lateral view of Sc element MMMC 4428 from MDAM 24. -P - lateral view of ?tortiform element MMMC 4430 from MDAM 35. $\bullet$ F-H - Panderodus sp. nov. A; lateral, lower and enlargement of lateral view of Sa element MMMC 4436 from MDAM 10. $\bullet$ I-M - Panderodus recurvatus (Rhodes, 1953). $\bullet$ I - lateral view of Sc element MMMC 4433 from MDAM 34. • J, K - lateral views of M elements; J - MMMC 4434 from B 15W; K - MMMC 4435 from MDAM 35. $\bullet$ L, M - lateral views of Sb elements; L - MMMC 4431 from MDAM 6; M - MMMC 4432 from GUND 1. Q Q-S - Pseudooneotodus beckmanni (Bischoff \& Sanneman, 1958), squat element MMMC 4437 attatched to a specimen of Pand. unicostatus from B15W; Q, R - upper views; S - lateral view. Scale bar $=0.1 \mathrm{~mm}$. 
1995 Panderodus recurvatus (Rhodes). - Dongal, fig. 5 O.

2003 Panderodus recurvatus (Rhodes). - Farrell, p. 122, pl. 1, fig. 2.

2003 Panderodus recurvatus (Rhodes). - Pyle \& Barnes, fig. 17.19.

2005 Panderodus recurvatus (Rhodes). - Trotter \& Talent, pl. 18, fig. 22.

2010 Panderodus recurvatus (Rhodes). - Corradini \& Corriga, pl. 1, figs 15-18.

2012 Panderodus recurvatus (Rhodes). - Corradini \& Corriga, fig. 6A.

Remarks. - Elements from the Mountain Dam and Booth sections and from a spot locality at Gunderbooka that are sharply recurved, with the point of recurvature approximately at the mid-length of the cone, are referred to Pand. recurvatus Rhodes. In some etched specimens the typical longitudinal costae are difficult to see and in some other specimens have disappeared completely.

Specimens of this taxon are generally rare in comparison with other panderodontids. This species is often seen as closely related to or even synonymous with Pand. panderi. Recurved panderodontid elements such as these are found sporadically in faunas of Ordovician to Devonian age and are possibly restricted by ecological conditions (Barrick et al. 2010). We choose to use the name Pand. recurvatus as the type material is Ludlow in age (Rhodes 1953).

\section{Panderodus rhytiodus sp. nov.} Figure 9

Holotype. - Sb element, specimen MMMC 4439 (Fig. 9B-D), from MDAM 11.

Type locality and horizon. - Sample MDAM 11 from the Mountain Dam Limestone, MDAM section on "Marobee" station approximately $90 \mathrm{~km} \mathrm{NW}$ of Condobolin, central New South Wales, Australia.

Etymology. - Rhytium (Greek), a drinking horn; in reference to the horn-like shape of the elements and their large, trumpet-like basal cavities.

Diagnosis. - A species of Panderodus in which, in lateral view, the elements of this quinquemembrate apparatus are horn-shaped and are characterised by a large, open basal cavity.

Description. - M element relatively broad, erect and gently recurved falciform with a straight basal margin and a rounded semi-quadrate basal cavity. In some specimens, a low, sharp costa is developed along the posterior margin of the upper surface.
Sa element erect, gently recurved similiform cone with a broadish base. Basal margin is gently curved with a small posterobasal heel and a large, open, oval basal cavity. A deep, narrow furrow, commencing from the apex of the element towards the posterior margin, runs diagonally down the cone towards the antero-basal corner of the element, gradually becoming indistinct as it approaches the basal margin.

$\mathrm{Sb}$ element a broad, squat, recurved asimiliform element with the point of recurvature less than half the height of the unit. Basal margin curves up towards a slight heel at the postero-basal corner and a large, open basal cavity is developed. A prominent furrow parallel to and close to the posterior margin is developed on the upper surface, running parallel to the margin until the point of recurvature where it continues in a gentle curve to terminate close to mid-width and just above the basal marginal wrinkle zone. A prominent, sharp costa extends down the lower surface of the cone commencing at the apex at mid-width and paralleling the posterior margin into the wrinkle zone.

Sc element a broad, squat, recurved, arcuate cone with the point of recurvature about three-quarters the height of the element. Basal margin is gently curved towards a slight heel at the postero-basal corner and a large, open basal cavity is developed. The basal cavity is evenly rounded except for a flattening towards the anterior margin of the upper surface where there is a slight flattening close to the termination of the costa developed on the upper surface. The costa commences close to the posterior margin of the apex of the element and runs in an even curve towards the antero-basal corner of the cone fading out close to the upper extent of the wrinkle zone.

$\mathrm{T}$ element a broad-based but slender recurved cone with the point of recurvature less than half the height of the element. The basal margin is straight and the basal cavity is elongately oval with the upper and lower surfaces slightly flattened. A narrow, sharp costa runs down the centre of the cone from the apex of the cusp and, from the point of recurvature, parallels the posterior margin.

Remarks. - This species is assigned to Panderodus on the grounds of its having longitudinal grooves and at least one costa on most lateral surfaces and a prominent wrinkle zone of striations along the basal margin.

The groove and costae of the Sb element of Pand. rhytiodus are reminiscent of those on elements of Decoriconus, but lack the coverage of striae on the upper and lower surfaces ( $c f$. Farrell 2003, pl. 12, figs 12, 17).

Panderodus unicostatus (Branson \& Mehl, 1933) Figures 8A-E, N-P, 32A, B

1933 Paltodus unicostatus n. sp.; Branson \& Mehl, p. 42, pl. 3, fig. 3 . 
1995 Panderodus unicostatus (Branson \& Mehl). - Simpson \& Talent, pp. 118-119, pl. 2, figs 1-32; see for further synonymy and add:

1985 Panderodus unicostatus unicostatus (Branson \& Mehl). - Wang, pp. 158-159, pl. 1, figs 1, 4, 5.

1995 Panderodus unicostatus (Branson \& Mehl). - Colquhoun, pl. 3, fig. 3.

1995 Panderodus unicostatus (Branson \& Mehl). Furey-Greig, pl. 2, figs 3-22.

1999 Panderodus unicostatus (Branson \& Mehl). - Cockle, p. 120, pl. 5, figs 1-8.

2000a Panderodus unicostatus (Branson \& Mehl). Göncüoğlu \& Kozur, fig. 5.9, 5.10, 5.12.

2000 Panderodus unicostatus (Branson \& Mehl). Winchester-Seeto \& Carey, fig. 7M-P.

2001 Panderodus unicostatus (Branson \& Mehl). - Rickards et al., fig. 2 .

2002 Panderodus unicostatus (Branson \& Mehl). - Talent et al., pl. 2, fig. I.

2003 Panderodus unicostatus (Branson \& Mehl). - Mawson et al., pl. 5, figs 7-9.

2003 Panderodus unicostatus (Branson \& Mehl). - Pyle \& Barnes, fig. 17.20-17.23.

2003 Panderodus unicostatus (Branson \& Mehl). - Farrell, pp. 122-123, pl. 1, figs 1, 3-5.

2003 Panderodus unicostatus (Branson \& Mehl). - Daniell, pl. 5, fig. 14.

2004 Panderodus unicostatus (Branson \& Mehl). - Farrell, p. 959, pl. 4, figs 10-14.

2005 Panderodus unicostatus (Branson \& Mehl). - Dahlqvist \& Bergström, fig. $12 \mathrm{n}-\mathrm{o}$.

2005 Panderodus unicostatus (Branson \& Mehl). - Talent et al., fig. $6 \mathrm{E}, \mathrm{F}$.

2005 Panderodus unicostatus (Branson \& Mehl). - Trotter \& Talent, pl. 18, figs 26, 27.

2006 Panderodus unicostatus (Branson \& Mehl). - Valentine et al., pp. 229-230, fig. 11a, b.

2007 Panderodus unicostatus (Branson \& Mehl). - Suttner, p. 21, pl. 5, figs 11, 12, pl. 6, figs 2-5.

2008 Panderodus unicostatus (Branson \& Mehl). - Eikhvald, p. 251, pl. 2, figs 7-11.

2009 Panderodus unicostatus (Branson \& Mehl). - Corriga \& Corradini, fig. $6 \mathrm{O}$.

2010 Panderodus unicostatus (Branson \& Mehl). - Corradini \& Corriga, pl. 1, figs 19, 20.

2010 Panderodus unicostatus (Branson \& Mehl). - Wang \& Aldridge, pl. 6, figs 1-16.

2012 Panderodus unicostatus (Branson \& Mehl). - Baranov, pl. 1, fig. 30.

2013 Panderodus unicostatus (Branson \& Mehl). - Wang, p. 66, pl. 6, figs 1-18.

Remarks. - Simpson \& Talent (1995) prepared an extensive synonymy for this globally distributed species; it is often abundantly represented in Panderodus faunas. It has been argued that it may be either closely related to or synonymous with Pand. simplex and Pand. equicostatus. We use the broad term "unicostatus" in this study as we have observed no obvious biostratigraphic significance in the distribution of these forms throughout the faunas, but we recognise that further study may reveal that this grouping includes more than a single taxon.

\section{Panderodus sp. nov. A}

Figure $8 \mathrm{~F}-\mathrm{H}$

?1980 "Drepanodus" sp.; Pickett, fig. 15Q.

?2007 Unassigned coniform element; Suttner, pl. 5, fig. 13.

Description. - The Sa element illustrated here has a tall, erect cusp that curves abruptly at about three-quarters of the unit height. The postero-basal margin extends downwards. The surface of the unit is covered by extremely fine striae that become more prominent in the wrinkle zone close to its basal margin. The inner face is slightly convex to planar with a prominent costa running close to and parallel with the anterior margin. The outer face is rounded towards the anterior margin but is constricted as it approaches the posterior margin. In basal view, the cavity has a "keyhole" shape, with constriction at the outer margin, rather than at the inner margin as is commonly the case in panderodids.

Remarks. - Three elements of this species were identified from the MDAM section: one $\mathrm{Sa}$ (similiform) element, one $\mathrm{Sb}$ (asimiliform), and one Sc (arcuatiform) element. All have a "keyhole" basal cavity with the constricted portion at the posterior-basal margin of the unit. The basal cavity morphology is a distinctive characteristic of the species. Despite the fact that all or almost all of the $\mathrm{S}$ series is represented in this collection, the species is left in open nomenclature because of the small number of specimens.

The element illustrated by Suttner (2007, pl. 5, fig. 13) appears to have a prominent costa close to the anterior margin and a "keyhole-shaped" basal cavity. It is only tentatively placed in synonymy here because it has a more pronounced postero-basal extension than our specimens. The element illustrated by Pickett (1980, fig. 15Q) is tentatively included in the synonymy for the same reasons.

Order Prioniodontida Dzik, 1976

Family Distomodontidae Klapper, 1981

Genus Coryssognathus Link \& Druce, 1972

Type species. - Cordylodus? dubius Rhodes, 1953. 
Coryssognathus dubius (Rhodes, 1953)

Figure 30A-G

1993 Coryssognathus dubius (Rhodes). - Miller \& Aldridge, pp. 242-253, pl. 1, figs 1-14, pl. 2, figs 1-18, pl. 3, figs 1-12, pl. 4, figs 1-15. Includes extensive synonymy.

1995 Coryssognathus dubius (Rhodes). - Simpson \& Talent, pp. 163-165, pl. 11, figs 5-10. Includes extensive synonymy.

1995 Coryssognathus dubius (Rhodes). - Miller, pl. 1, figs $9,12$.

1997 Coryssognathus dubius (Rhodes). - Serpagli et al., pp. 240-242, pl. 1, figs 1-19.

1998a Coryssognathus dubius (Rhodes). - Corradini et al., pl. 3.3.1, fig. 15 .

1999 Coryssognathus dubius (Rhodes). - Cockle, p. 120, pl. 4 , fig. 20.

1999 Coryssognathus dubius (Rhodes). - Viira, pl. 1, figs 9-12.

1999 Coryssognathus dubius (Rhodes). - Talent \& Mawson, pl. 3, figs 6-8.

2001 Coryssognathus dubius (Rhodes). - Rickards et al., fig. $2 \mathrm{w}$.

2003 Coryssognathus dubius (Rhodes). - Talent et al., pl. 1, figs 1, 2.

2004 Coryssognathus dubius (Rhodes). - Farrell, pp. 959-960, pl. 4, figs 1-9.

2006 Coryssognathus dubius (Rhodes). - Valentine et al., pp. 225-227, fig. 11e, f.

2006 Coryssognathus dubius (Rhodes). - Farrell, fig. 5C, G-J.

2009 Coryssognathus dubius (Rhodes). - Corriga \& Corradini, p. 166, fig. 6I-L.

2009 Coryssognathus dubius (Rhodes). - Corriga et al., pl. 2, fig. 8.

2010 Coryssognathus dubius (Rhodes). - Corradini \& Corriga, pl. 1, figs 8-11.

2012 Coryssognathus dubius (Rhodes). - Corradini \& Corriga, fig. 6E, F.

Remarks. - Miller \& Aldridge (1993) reconstructed this taxon as a septimembrate apparatus including three element types in the $\mathrm{P}$ position, and discussed means of discriminating this taxon from species of Pelekysgnathus. Simpson \& Talent (1995) partially reconstructed the taxon from Claire Creek and compiled an extensive synonymy. In our study no $\mathrm{Pa}$ elements were recovered, but $\mathrm{Pa}$ elements ascribed to $\mathrm{Pe}$ lekysgnathus were recovered in a number of samples. None of these Pa elements has the characteristic basal cavity tips beneath each denticle suggesting progressive accretion of coniform structures during ontogeny, and are therefore kept separate herein. The above synonymy builds on that of Miller \& Aldridge (1993) and Talent \& Simpson (1995).
Australian occurrences of Coryssognathus dubius have previously been considered to have an upper range within the Ludlow (Simpson 1995), but Serpagli et al (1997) reported an upper range extending into the Přídolí in Sardinia. In Australia this species has been obtained from the Yass Basin (Link \& Druce 1972), the Trundle region (Pickett \& Ingpen 1990), the Murda Syncline (Pickett \& McClatchie 1991), the Kildrummie Formation (De Deckker 1976), the Claire Creek limestone (Simpson \& Talent 1995), Cowombat Flat (Simpson et al. 1993) and the Cobra Formation (Valentine et al. 2006), occurrences that all appear to be restricted to the Ludlow according to associated faunas. Simpson \& Talent (1995, p. 165) reported an occurrence of $C$. dubius at Native Dog Flat in strata above a single occurrence of Ozarkodina remscheidensis eosteinhornensis. Farrell (2004) reported the highest occurrence of $C$. dubius in the Camelford Limestone some $66 \mathrm{~m}$ below the first occurrence of a specimen reported as Icriodus woschmidti hesperius, but there were no Přídolí index taxa reported from this interval. In a subsequent study of "tectonically emplaced" strata from the Camelford Limestone, Farrell (2006) recorded $C$. dubius some $25 \mathrm{~m}$ above an occurrence of $O$. r. eosteinhornensis. It is therefore likely that C. dubius extends into the Přídolí in Australia as well as in Sardinia although the orientation of Farrell's (2006) section is unclear.

Family Icriodontidae Müller \& Müller, 1957

\section{Genus Icriodus Branson \& Mehl, 1938}

Type species. - Icriodus expansus Branson \& Mehl, 1938.

\section{Icriodus ampliatus sp. nov.}

Figures 11, 32C, D

1980 Icriodus woschmidti Ziegler. - Pickett, p. 70, fig. 3A-D.

Holotype. - I element, specimen MMMC 4451 (Fig. 11A-C), from MDAM 37.

Type locality and horizon. - Sample 37 from the Mountain Dam Limestone in the MDAM section on "Marobee" station approximately $90 \mathrm{~km} \mathrm{NW}$ of Condobolin, central New South Wales, Australia.

Etymology. - Ampliatus (Latin), enlarged, expanded, widened; in reference to the obtuse angle $\left(120^{\circ}\right.$ or more $)$ formed between the outer lateral process and the medial row of nodes of the Pa element.

Diagnosis. - A species of Icriodus characterised by the I 
element being spindle- or tower-shaped and having a well-developed denticulate outer lateral process connecting to the posteriormost medial denticle that extends posteriorly beyond the lateral nodes at an angle of at least $120^{\circ}$.

Description. - The main process of representative I elements is generally spindle-shaped (eta morph) or coneshaped (beta morph) with high, pointed lateral nodes extending transversely to form ridges that meet at the base of smaller, less distinct medial nodes. In upper view the lateral and medial nodes appear as continuous ridges, but in lateral view the lateral nodes can be seen to be much higher and larger than the medial nodes to which they are connected. A very narrow, even hair-like, median longitudinal ridge connects the diminutive medial nodes. The spacing between the rows of nodes is considerably wider anteriorly than towards the posterior of the spindle. A well-developed denticulate outer lateral process connects with two or three medial denticles that extend posteriorly beyond the lateral nodes, forming an angle in excess of $120^{\circ}$. An unornamented inner spur is developed on the upper surface of the rectangular basal cavity. The upper surface of the outer basal cavity is rounded opposite the spindle, becoming rapidly narrower from the junction of the spindle with the spur.

Remarks. - This species shares several characteristics of Icriodus steinachensis eta and beta morphs and some features of I. claudiae alpha morph. It also has a similarly proportioned spindle and spacing of the transverse denticle rows, and a similar basal cavity to I. steinachensis gamma morph, but in all cases the angle at which the posterior process diverges from the spindle axis is considerably greater, in excess of $120^{\circ}$. Although the spindle of I. claudiae alpha morph is more slender than in the morphs of I. steinachensis, the angle at which the outer posterior process meets the medial denticle row is greater in I. claudiae, approaching the size of the angle in this new species.

Murphy \& Matti (1982, p. 58) pointed out that, although conodont faunas of middle sulcatus Zone age in Nevada display a full range of variation between I. claudiae alpha morph and I. steinachenis beta morph, there is a "morphological gap ... between I. claudiae and I. steinachensis in the upper sulcatus Zone". Being intermediate between the two species, I. ampliatus closes this "morphological gap". Based on evolutionary arguments, we conclude that the age of this new species falls into the upper part of the sulcatus Zone and may extend into the kindlei Zone.

In their study of I. steinachensis and I. claudiae lineages, Murphy \& Cebecioğlu (1984, fig. 4) plotted length versus width of specimens from UCR localities 8576 and 8973 in central Nevada. The results show a gap between the data for the two species. Data from I. ampliatus, when added to Murphy \& Cebecioğlu's scatter diagram, show that the new species plots between I. steinachensis and I. claudiae, in the "morphological gap" mentioned by Murphy \& Matti (see Fig. 7 herein).

\section{Icriodus angustoides angustoides Carls \& Gandl, 1969} Figure 10A, B

1969 Icriodus angustoides angustoides n. ssp.; Carls \& Gandl, p. 176, pl. 15, figs 15, 16.

1969 Icriodus angustoides angustoides Carls \& Gandl. Carls, pp. 325-326, pl. 3, figs 13, 14, pl. 4, fig. 2.

1975 Icriodus angustoides angustoides Carls \& Gandl. Carls, p. 414, pl. 3, fig. 48.

1975 Icriodus angustoides angustoides Carls \& Gandl. Ziegler in Ziegler, pp. 71, 72, Icriodus pl. 6, figs 8, 9.

?1980 Icriodus cf. angustoides Carls \& Gandl. - Pickett, pp. 70-71, fig. 3E-G.

1985 Icriodus angustoides angustoides Carls \& Gandl. Wang, p. 153, pl. 2, figs 21, 23.

2002 Icriodus angustoides angustoides Carls \& Gandl. García-López et al., pl. 1, fig. 16.

Remarks. - The I element of I. a. angustoides illustrated by Wang (1985, pl. 2, fig. 23) from Inner Mongolia has a greater number of rows of nodes than are usually seen in this taxon, at least seven, but this might be a gerontic specimen. Pickett (1980, fig. 3F, G) figured a poorly preserved I element from the White Tank Limestone, western New South Wales, as I. cf. angustoides, and stated that the posteriormost denticle of the crest "is not appreciably higher that the one in front of it". Although no lateral view of the specimen was shown, it appears from the illustration that it indeed has a higher posterior denticle and can therefore be assigned to I. a. angustoides.

Icriodus angustoides angustoides has been reported together with I. curvicauda from horizons of sulcatus Zone age in Spain, in the East Iberian Chain, Aragon (Carls \& Gandl 1969, Carls 1975) and in the Sierra de Guadarrama (Bultynck 1976).

Icriodus curvicauda Carls \& Gandl, 1969 Figure 10C-M

1969 Icriodus huddlei curvicauda n. subsp.; Carls \& Gandl, pp. 180-182, pl. 16, figs 10-15 (only).

1975 Icriodus huddlei curvicauda Carls \& Gandl. - Carls, p. 413 , pl. 3, figs $49-53$.

1976 Icriodus curvicauda Carls \& Gandl. - Bultynck, pl. 6 , fig. 6 .

1994 Icriodus curvicauda Carls \& Gandl. - Valenzuela-Ríos, pp. 95-96, pl. 8, fig. 30. 


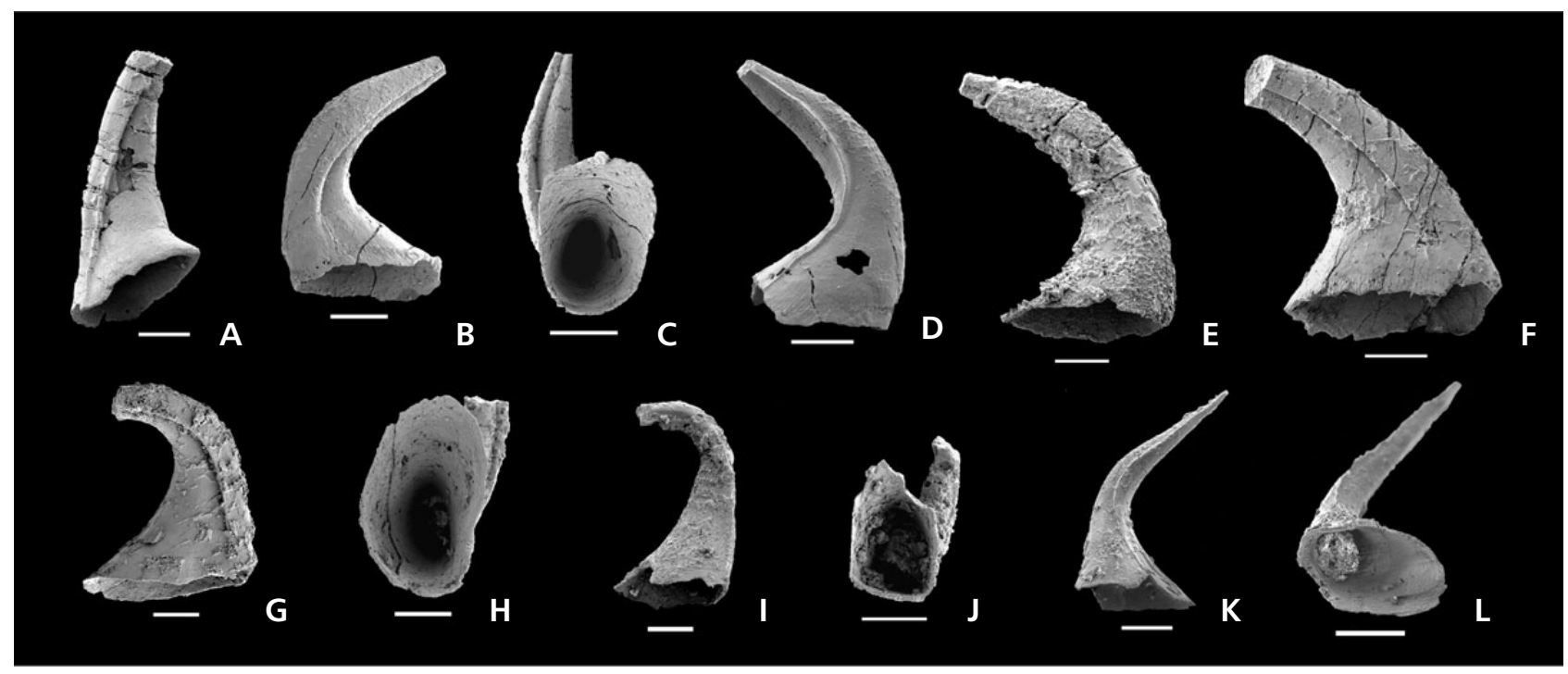

Figure 9. Panderodus rhytiodus sp. nov. • A - lateral view of Sa element MMMC 4438 from MDAM 10. $\bullet$ B-D - left lateral, lower and right lateral views of Sb element, holotype MMMC 4439 from MDAM 11. E, F- lateral views of Sb elements; E-MMMC 4440 from MDAM 15; F-MMMC 4441 from MDAM 35. $\bullet \mathrm{G}, \mathrm{H}-$ lateral and lower views of Sc element MMMC 4441 from MDAM 17. $\bullet$ I, J - lateral and lower views of M element MMMC 4442 from MDAM 11. K, L - lateral and lower views of tortiform $(\mathrm{T})$ element MMMC 4443 from MDAM 24. Scale bar $=0.1 \mathrm{~mm}$.

1999 Caudicriodus curvicauda (Carls \& Gandl). - Benfrika, p. 316, pl. 1, fig. 13 .

2002 Icriodus curvicauda Carls \& Gandl. - García-López \& Sanz-López, pl. 1, figs 1, 2.

2004b Caudicriodus curvicauda (Carls \& Gandl). - Slavík, fig. 11.4-5.

Remarks. - The I element of I. curvicauda is very narrow with three distinct rows of cone-shaped denticles that are wider apart anteriorly than posteriorly. These contrast with the denticles of $I$. a. angustoides that form almost continuous horizontal bars. In I. curvicauda the extension of the median row of denticles curves gently to form a lateral process.

Ziegler (in Ziegler 1975) recorded the stratigraphic range of I. curvicauda as sulcatus to dehiscens zones.

\section{Icriodus sp. aff. I. celtibericus (Carls \& Gandl, 1969)} Figure 10N-R

1980 Icriodus aff. I. celtibericus (Carls \& Gandl). - Klapper \& Johnson, pl. 2, figs 18, 23, 24.

Remarks. - The I element illustrated (Fig. 10P-R) from near B $15 \mathrm{E}$ is strikingly similar to the specimen from McColley Canyon, Nevada (Klapper \& Johnson 1980, pl. 2, figs 18,24 ) in having wider spacing of lateral row denticles in the anterior part of the platform than in the posterior part of the platform. The Nevada specimen, however, has eight rows of denticles compared to five rows on the platform of the Booth Limestone specimen, and the Nevada specimens illustrated are considerably larger and therefore more mature than those illustrated herein. Klapper \& Johnson (1980) recorded an age of sulcatus and kindlei zones for horizons from which they obtained their material. Our specimens also bear some resemblance to Caudicriodus ruthmawsonae Drygant (2010, pl. 3, figs 1, $2,6)$ but they are less elongate, the lateral extension of the basal cavity is clearly anteriorly oriented, and there are fewer rows of denticles.

\section{Genus Pelekysgnathus Thomas, 1949}

Type species. - Pelekysganthus inclinatus Thomas, 1949.

Pelekysgnathus inequalis sp. nov.

Figure $12 \mathrm{G}-\mathrm{O}$

Holotype. - I element, specimen MMMC 4461 (Fig. 12G, H), from B $16 \mathrm{C}$.

Type locality and horizon. - Sample B 16C from the Booth Limestone on Multagoona Anticline, $2 \mathrm{~km}$ southwest of Beulah Tank, "Manuka".

Etymology. - Inequalis (Latin), unlike, different, unequal; in reference to the irregular shape of the basal cavity and the profile of denticles in lateral view of the I element.

Diagnosis. - A species of Pelekysgnathus with its I ele- 


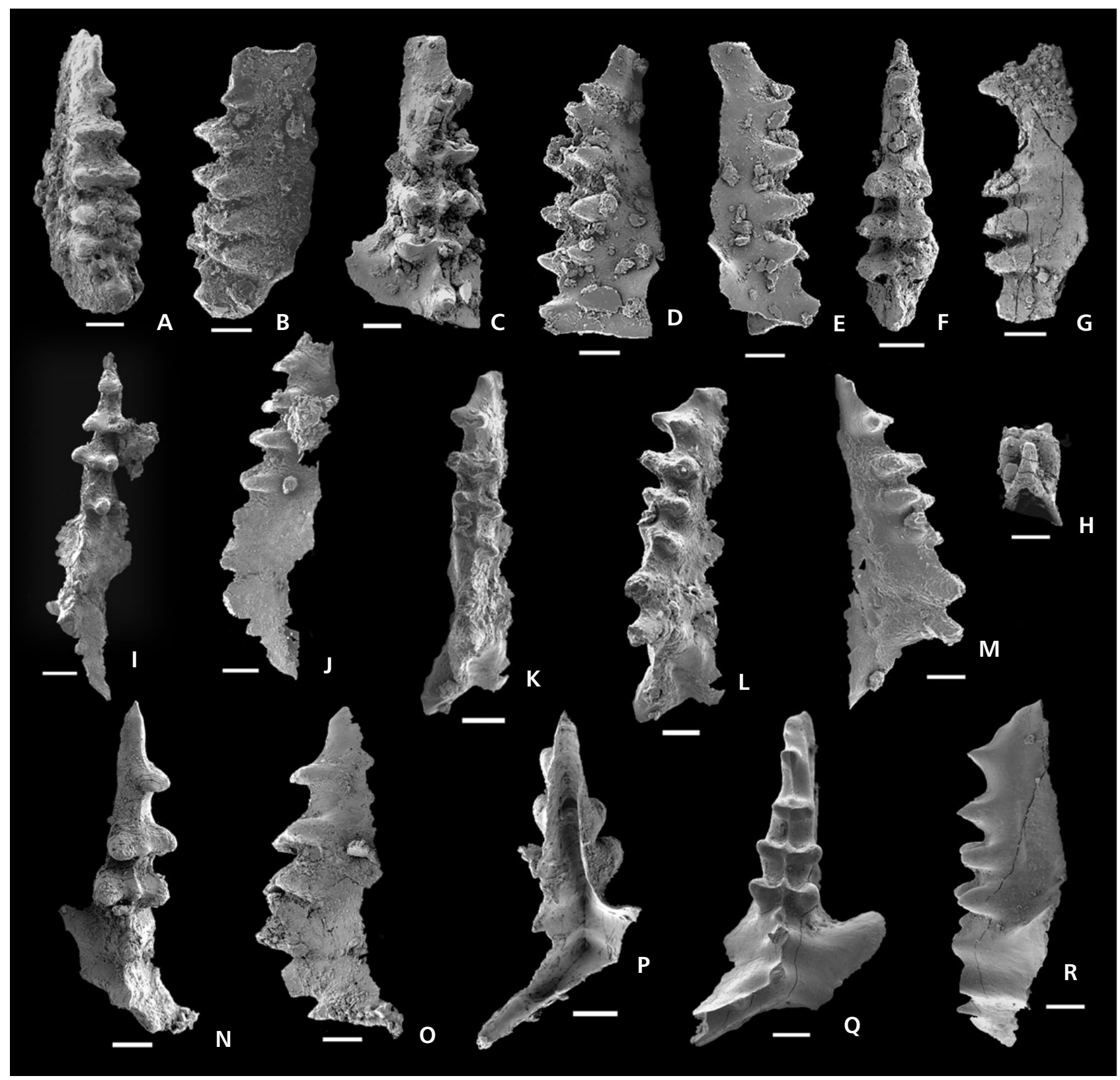

Figure 10. A, B - Icriodus angustioides angustioides Carls \& Gandl, 1969; upper and lateral views of I element MMMC 4444 from B 11D. - C-M - Icriodus curvicauda Carls \& Gandl, 1969. • C-E - upper, inner lateral and outer lateral views of I element MMMC 4445 from GUND1. - F-H - upper, lateral and anterior views of I element MMMC 4446 from GUND 1. $\bullet$ I, J - upper and inner lateral views of I element MMMC 4447 from BTL B. • K-M - upper, upper oblique and inner lateral views of I element MMMC 4448 from BTL 1. • N-R - Icriodus sp. aff. I. celtibericus (Carls \& Gandl, 1969). • N-P - upper, lateral and lower views of I element MMMC 4449 from MDAM 37. $\bullet$, R - upper and outer lateral views of I element MMMC 4450 from B 15E. Scale bar $=0.1 \mathrm{~mm}$.

ment, in lateral view, characterised by the denticles in the posterior half being high and individual, and in the anterior half lower, fused and irregular.

Description. - The I element in lateral view has its denticles in the posterior portion high, discrete, pointed and laterally compressed. Denticles in the anterior half are fused and somewhat irregular in profile. The basal cavity in the posterior half is narrow and rounded at the posterior extremity. At midpoint the basal cavity expands abruptly making an ear-like lobe on the inner margin that decreases in width rapidly at about three-quarters the length of the unit and continues as a narrow groove to the anterior end. Simultaneously, at mid length the basal cavity expands rapidly on the outer margin and tapers more evenly to the anterior end of the blade. 


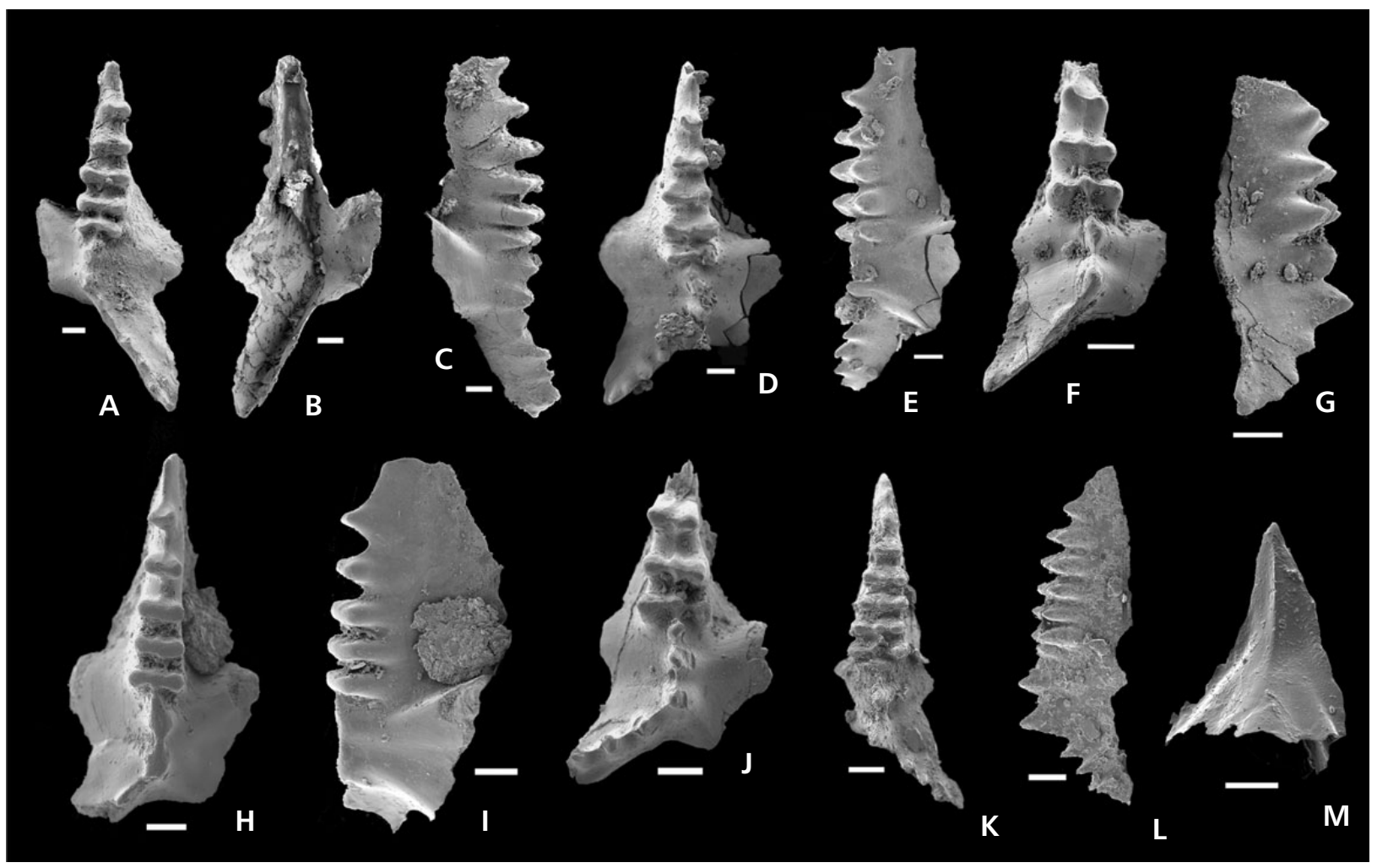

Figure 11. Icriodus ampliatus sp. nov. $\bullet$ A-C - upper, lower and outer lateral views of I element, holotype MMMC 4451 from MDAM $37 . \bullet$ D, E - upper and outer lateral views of I element AMF 4452 from BE. $\bullet$, G - upper and inner lateral views of I element MMMC 4453 from B $15 \mathrm{~W}$. $\bullet$ H, I - upper and outer lateral views of I element MMMC 4454 from B 15W. $\bullet J-$ upper view of I element MMMC 4455 from B 15E. $\bullet \mathrm{K}, \mathrm{L}-$ upper and inner lateral views of I element MMMC 4456 from B 13. $\bullet$ M - lateral view of $S_{2}$ element MMMC 4457 from MDAM 139.5. Scale bar $=0.1 \mathrm{~mm}$.

$\mathrm{S}_{2}$ element is acodinan with a keel on either one or on both margins. The base of the unit is slightly elliptical to semiquadrate in shape.

$\mathrm{M}_{2}$ element is a simple cone with the surface and especially the base covered in fine striations. The base of the unit is slightly elliptical.

Remarks. - Little attention has been given to Early Devonian pelekysgnathans so, despite relatively low numbers of elements, we decided that this assemblage of pelekysgnathan elements from the Booth and Mountain Dam limestones should be described as a new species. Note that the $\mathrm{S}_{2}$ elements show slight morphological variations and could represent the three members of a symmetry transition series.

Irregularity of the denticles and the shape of the basal cavity separate Pel. inequalis from other species of Pelekysgnathus that might normally be found in faunas of this age, namely Pel. serratus (Jentzsch, 1962) and Pel. klamathensis (Savage, 1977). As in many Pelekysgnathus species the basal cavity in the scaphate I element is flared, but in this case the expansion is markedly asymmetric. This asymmetry is similar to that seen in $\mathrm{Pa}$ elements of Amydrotaxis but is less pronounced.

Based on the occurrence of Pel. inequalis in horizons with
I. ampliatus and $O z$. buchanensis, the new species has a time range from late in the sulcatus Zone to the pireneae Zone.

\section{Pelekysgnathus sp. cf. Pel. furnishi Klapper, 1969}

Figure 12A-E

cf. 1969 Pelekysgnathus furnishi Klapper; pp. 11-12, pl. 2, figs 12-21, 28, 29.

1972 Pelekysgnathus furnishi Klapper. - Klapper \& Philip, p. 102, pl. 3, figs 15-17.

1979 Pelekysgnathus furnishi Klapper. - Chatterton, p. 203, pl. 7, fig. 29.

Remarks. - The two juvenile I elements from the Mountain Dam and Booth limestones resemble the specimen of Pel. furnishi illustrated by Chatterton (1979, pl. 7, fig. 29). One of our specimens (Fig. 12D) appears close in morphology to Pel. serratus brunsvicensis Valenzuela-Ríos. The specimen, however, appears incomplete and it is not possible to ascertain the nature of the posteriormost primary denticle in relation to the others, one of the diagnostic features of that subspecies. Pelekysgnathus serratus brunsvicensis has been used to correlate Barrandian Pragian strata 


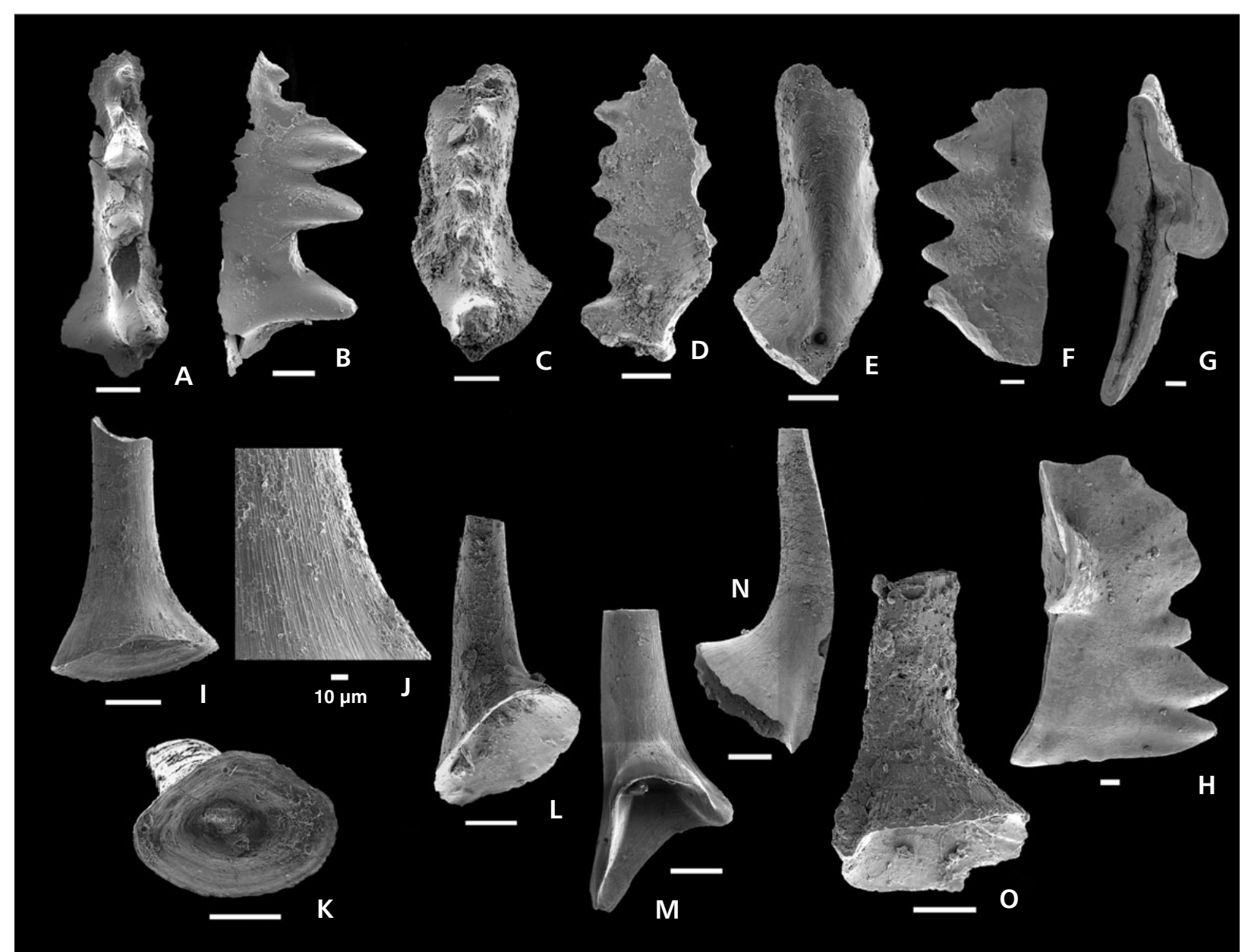

Figure 12. A-E - Pelekysgnathus sp. cf. Pel. furnishi Klapper, 1969. • A, B - upper and lateral views of I element MMMC 4458 from MDAM 37. - C-E - upper, lateral and lower views of I element MMMC 4459 from B 11D. • F - Pelekysgnathus sp. cf. Pel. sp. A Uyeno \& Bultynck, 1993; lateral view of I element MMMC 4460 from BTSW. $\bullet \mathrm{G}-\mathrm{O}-$ Pelekysgnathus inequalis sp. nov. $\bullet \mathrm{G}, \mathrm{H}-$ lower and lateral views of I element, holotype MMMC 4461 from B 16C. $\bullet$ I-K - lateral, lateral enlarged and lower views of M 2 element MMMC 4462 from B 16G. $\bullet$ L - lateral views of M2 element MMMC 4463 from B 16A. $\bullet M$ - lateral view of ?pathological M2 element MMMC 4464 from B 16A. $\bullet N-$ lateral view of $S_{2}$ element MMMC 4465 from B $16 \mathrm{G}$. - $\mathrm{O}$ - lateral view of $\mathrm{S}_{2}$ element MMMC 4466 from B 16G. Scale bar $=0.1 \mathrm{~mm}$ except in $\mathrm{J}$.

with the Spanish Pyrenees (Slavík et al. 2007). Greater sampling is required to establish whether the taxon is present in the Booth Limestone.

\section{Pelekysgnathus sp. cf. Pel. sp. A Uyeno \& Bultynck, 1993 \\ Figure 12F}

Remarks. - One damaged specimen resembles the I element of the new but unnamed species illustrated by Uyeno \& Bultynck (1993, pl. 2.4, fig. 13) from the lower Middle Devonian of the Kwatoboahegan Formation, northern Ontario. The denticles of the specimen from the Booth Limestone (locality BTSW) are more regular, although the nature of the free pointed tips and the proportions of the blade are similar.
Pelekysgnathus sp. A? Corriga \& Corradini, 2009 Figure $30 \mathrm{H}-\mathrm{J}$

1995 Pelekysgnathus index Klapper \& Murphy. - Barca et al., pl. 4, figs 4, 5 .

1998 Pelekysgnathus index Klapper \& Murphy. - Serpagli et al., p. 110, pl. 1.1.2, figs 4, 5.

?2006 Pelekysgnathus serratus cf. elata Carls \& Gandl. Farrell, fig. 5K-M.

?2009 Pelekysgnathus sp. A. - Corriga \& Corradini, pp. 165-166, fig. $6 \mathrm{M}$.

Remarks. - A small number of distinctive Pa elements was obtained in this study. The elements are arched, with compressed and partly fused denticles. The basal cavity is narrow, has a distinctively rounded posterior margin and occupies only one-third to one-half the length of the blade. 
This is a poorly known taxon and the classification of the Myola specimens is considered tentative. They are not grouped with any of the $\mathrm{S}$ elements in this study as Miller \& Aldridge (1993) noted that symmetry transition elements of Pelekysgnathus are coniform with rounded cusps unlike Coryssognathus. The Pa elements closely fit the description given by Corriga \& Corradini (2009, pp. 165-166), in particular the small symmetrical basal cavity in comparison with the larger flared basal cavity of $P$. index Klapper \& Murphy. The illustration of their single specimen (Corriga \& Corradini 2009, fig. 6M), however, is incomplete and does not show the shape of the basal cavity; it also does not appear as strongly arched as the Myola specimens. Except for the arching, morphology is similar to the Early Devonian Pelekysgnathus serrata elongata Carls \& Gandl.

Farrell (2006, fig. 5K-M) illustrated some specimens from limestone blocks within the Barnby Hills Shale in New South Wales. Those specimens are also incomplete but are very close in morphology to the Myola specimens. The above synonymy is therefore considered provisional at this stage until complete elements from different areas can be compared.

This species in Sardinia is restricted to low in the crispa Zone (Corriga \& Corradini 2009). It co-occurs with the index species well below the first appearance of taxa typically associated with Prrídolí strata such as Ozarkodina eosteinhornensis s.1. (Corriga \& Corradini 2009, table 1). The pelekysgnathid reported by Farrell (2006, table 1), however, is recorded as occurring stratigraphically higher than Ozarkodina remscheidensis eosteinhornensis. Farrell's sections did not produce faunas indicative of either late Ludlow or Early Devonian strata, and their orientation in a complexly deformed region may require reassessment. The true biostratigraphic utility of this species is therefore yet to be established.

Order Prioniodinida Sweet, 1988

Family Prioniodinidae Bassler, 1925

\section{Genus Erika Murphy \& Matti, 1982}

Type species. - Erika divarica Murphy \& Matti, 1982.
Erika divarika Murphy \& Matti, 1982

Figure 30K, L

1982 Erika divarica n. sp.; Murphy \& Matti, pp. 41-44, pl. 6, figs 1-13.

?1989 Erika sp. - Sorentino, p. 90, pl. 5, figs 19, 20.

Remarks. - This taxon was originally reported from the Early Devonian delta Zone and reconstructed as a seximembrate apparatus lacking a platform element. Only two elements of the symmetry transition series were obtained in our study. Both have the diagnostic alternating divergent denticles on both processes. Miller \& Märss (1999) tentatively reconstructed similar elements from the Přídolí Downtown Sandstone as an ?ozarkodinid taxon. From the illustrations, however, their S elements do not clearly show alternating divergent denticles (e.g. Miller \& Märss 1999, pl. 1, fig. 13). The Myola specimens are therefore considered as the first Silurian documentation of this species. Jeppsson (pers. comm. 2009) found the same taxon from the lower Ludlow of Gotland. It therefore appears to be a long ranging but rare taxon poorly represented in conodont faunas.

\section{Genus Oulodus Branson \& Mehl, 1933}

Type species. - Cordylodus serratus Stauffer, 1930.

Remarks. - A possible evolutionary sequence of the three species Oulodus tenustriatus Pickett, Oul. paucistriatus Mawson and Oul. astriatus sp. nov. is suggested by morphological changes, namely a reduction in striations, and by stratigraphic criteria.

Three broken elements (Fig. 31G-I) are tentatively included in this genus; we reference some visual similarity with previously illustrated forms but retain open nomenclature.

Oulodus sp. cf. Oul. walliseri (Ziegler, 1960) Figure 13A-I

cf. 1980 Delotaxis walliseri (Ziegler). - Pickett, pp. 79-81, fig. 10A-M.

Figure 13. A-I-Oulodus sp. cf. Oul. walliseri Ziegler, 1960. • A - lateral view of Pa element MMMC 4467 from MDAM 36 . B - lateral view of Pa element MMMC 4468 from B 15W. $\bullet$ C, F - lateral and lower views of Pb element MMMC 4469 from B 15E. D - lateral view of M element MMMC 4470 from MDAM 36. $-\mathrm{E}$ - lateral view of Sc element MMMC 4471 from MDAM 22. • G - lateral view of Sa element MMMC 4472 from MDAM 16. $\bullet \mathrm{H}$ - lateral view of Sa element MMMC 4473 from MDAM 37. • I - lateral view of Sa element MMMC 4474 from MDAM $28 . \bullet J-O$ - Oulodus astriatus sp. nov. $\bullet \mathrm{J}$ - lateral view of Pa element, holotype MMMC 4475 from B $16 \mathrm{~L} \cdot \bullet \mathrm{K}-$ lateral view of Pa element MMMC 4475 from B $16 \mathrm{~L}$. $\bullet \mathrm{L}-$ lateral view of Pb element MMMC 4476 from B 16L. $\bullet$ M - lateral view of Sa element MMMC 4477 from B 16L. $\bullet N-1$ ateral view of ?Sb element MMMC 4478 from GUND 3. $\bullet$ - lateral view of Sc element MMMC 4479 from BTL2. Scale bar $=0.1 \mathrm{~mm}$. 


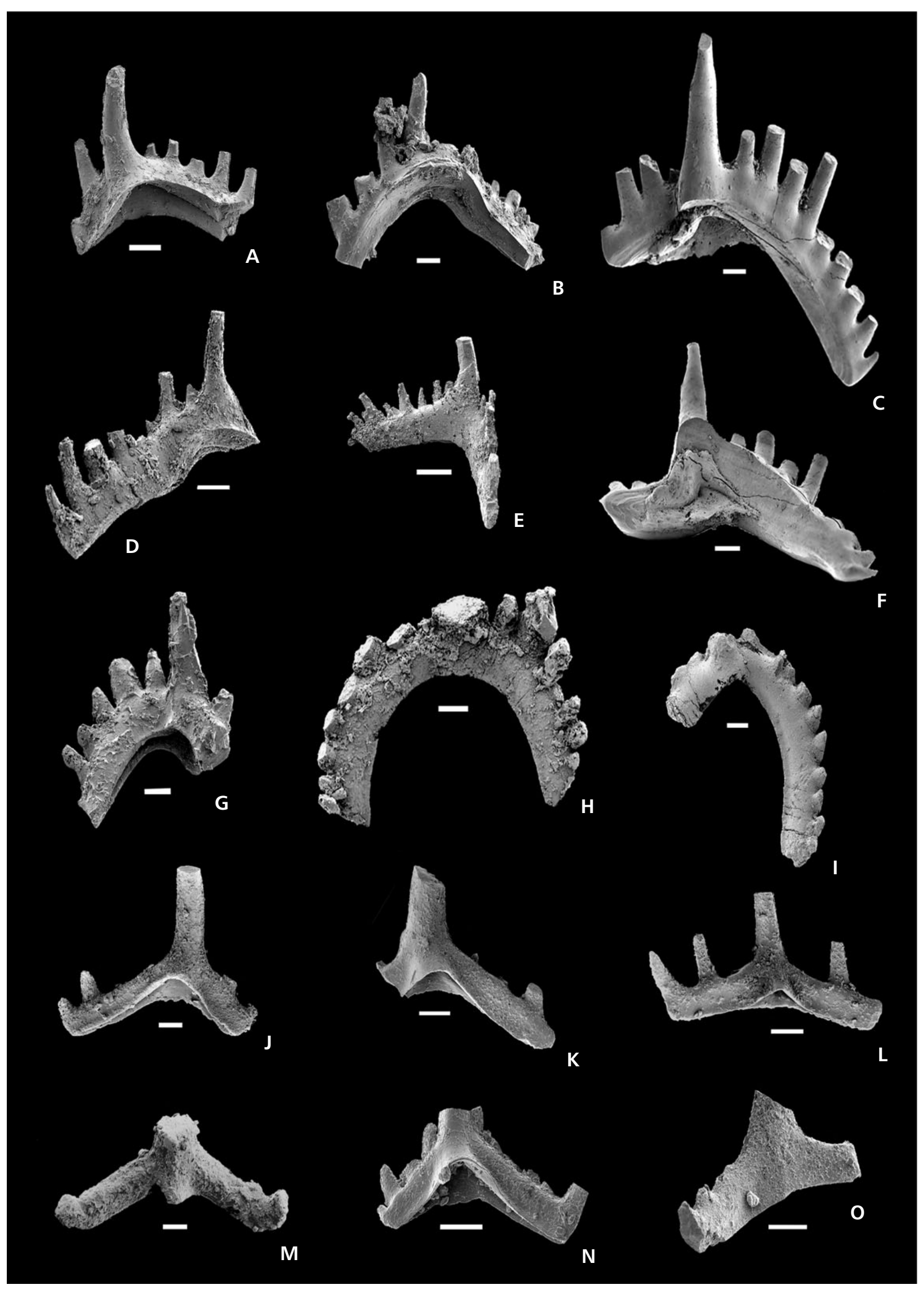


cf. 1994 Oulodus cf. walliseri (Ziegler). - Mawson \& Talent, fig. 14A-I.

Remarks. - Pickett (1980, p. 81) recognised all six elements of Oul. walliseri as having a "strongly exert basal cavity". Those identified by Mawson \& Talent (1994) as Oul. cf. walliseri from the $\mathrm{BOO}$ and TQ sections through the Coopers Creek Limestone, at the Boola and Tyers quarries, Victoria, and from spot localities from the Tyers-Boola, Deep Creek, and Marble Creek areas, differ from Oul. walliseri in having basal cavities that are more elongate and lack the pronounced lip of the basal cavity referred to by Pickett (1980).

\section{Oulodus astriatus sp. nov.}

Figure 13J-O

Holotype. - Pa element, specimen MMMC 4475 (Fig. 13J), from B 16L.

Type locality and horizon. - Sample B 16L from the Booth Limestone, Multagoona Anticline, "Manuka".

Etymology. - Astriatus (Latin), without striations, in reference to the lack of striations present on the main cusp of each element of the apparatus.

Diagnosis. - A species of Oulodus in which all elements are characterised by a lack of longitudinal ridges or striations adorning the mains cusp and by having only a few, stubby denticles set along lateral processes, generally at irregular intervals.

Description. - Pa element digyrate with anterior and posterior processes slightly twisted with respect to one another, each bearing one or two peg-like denticles; main cusp slightly proclined and oval in cross-section. The ovate basal cavity beneath the main cusp tapers to a groove in both directions below the lateral processes.

$\mathrm{Pb}$ element digyrate with narrow lateral processes slightly twisted relative to each other and bent downwards to form an angle of approximately $90^{\circ}$ beneath the main cusp. Each lateral process bears up to three small, irregularly spaced, blunt peg-like denticles. The basal cavity is similar to that of the Pa element.
$\mathrm{M}$ element has not yet been obtained from the areas studied.

Symmetry transition series consists of alate, digyrate and bipennate elements, all with narrow processes with few irregularly spaced, short, peg-like denticles. All elements have relatively smaller basal cavities than the $\mathrm{Pa}$ and $\mathrm{Pb}$ elements but are somewhat expanded beneath the main cusp and taper towards the distal extremities.

Remarks. - Despite the paucity of specimens representative of the new species, it has been described here to illustrate what superficially looks to be an evolutionary sequence from Oul. tenustriatus, to Oul. paucistriatus, to Oul. astriatus, three species developing a few stubby denticles along the lateral processes. The first of this sequence, Oul. tenustriatus, was described by Pickett (1980) from the Rookery Limestone Member in association with conodonts of supposed pesavis Zone age but is argued here to be from the sulcatus Zone. Oulodus tenustriatus has up to 12 longitudinal striations on the main cusp of all elements in the apparatus. The next species in the sequence, Oul. paucistriatus, was described by Mawson (in Wall et al. 1995) from the Lilydale Limestone, Victoria, from horizons of kindlei or pireneae zone age. However, the last species, Oul. astriatus from the upper Booth Limestone, is associated principally with conodonts of pireneae zone age, thus indicating a possible evolutionary pattern developed in this lineage. Larger collections of material are essential to verify this hypothesis.

\section{Oulodus paucistriatus Wall, Mawson, Talent \& Cooper, 1995}

Figure 14A-F

1994 Oulodus sp.; Mawson \& Talent, figs 14L-N, 16E.

1995 Oulodus paucistriatus; Wall et al., pp. 377-378, pl. 2, figs $8-17$.

Remarks. - The presence of few (up to six) striations on the main cusps of each element of the apparatus separates this species from other species of the genus. The digyrate $\mathrm{Pa}$ element from Booth 16C (Fig. 14A) has the anterior and posterior processes slightly twisted with respect to each other. The main cusp is somewhat procline, circular in

Figure 14. A-F-Oulodus paucistriatus Wall et al., 1995. • A - lateral view of Pa element MMMC 4480 from B $16 \mathrm{C}$. $\bullet$ B - lateral view of ?Pa element MMMC 4481 from B 16A. • C - lateral view of Pb element MMMC 4482 from B 16A. • D - lateral view of Sc element. MMMC 4483 from B 16A. - E - lateral view of ?Sb element MMMC 4484 from B 16C. • F - lateral view of ?Sb element MMMC 4485 from B 9. • G-M - Oulodus? Apparatus A. - $\mathrm{G}$ - lateral view of ?Pa element MMMC 4486 from B 16G. $\bullet \mathrm{H}$ - lateral view of Pb element MMMC 4487 from B $16 \mathrm{C}$. $\bullet$ I, J - lateral and lower views of Sa element MMMC 4488 from B 16C. $\bullet$ K - lateral view of Sb element MMMC 4489 from B 16C. $\bullet$ L - lateral view of ?Sc element MMMC 4490 from B 16C. $\bullet \mathrm{M}$ - lateral view of M element MMMC 4491 from B 16G. $\bullet$ N-P - Oulodus? Apparatus B. $\bullet$ N, O - lateral and lower oblique views of Pb element MMMC 4492 from MDAM 37. $\bullet P-$ lateral view of ?Sa element MMMC 4493 from B 11D. Scale bar $=0.1 \mathrm{~mm}$. 


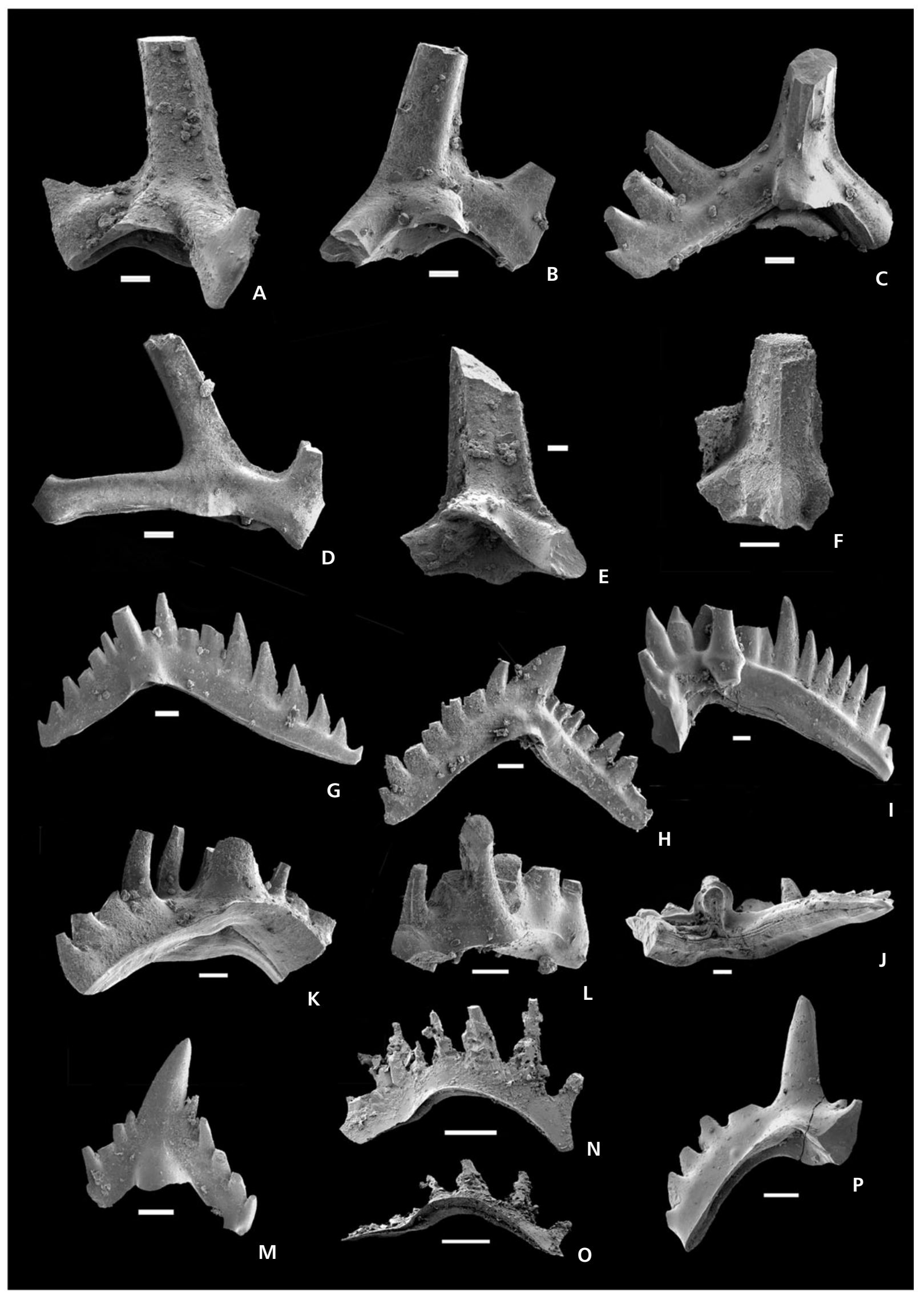


cross-section and has an ornament of only two marginal striations. The $\mathrm{Pb}$ element from Booth 16A (Fig. 14C) is also digyrate and has short, stout processes twisted in relation to one another with up to three stubby denticles on each.

Oulodus paucistriatus can be separated from Oul. tenustriatus, described by Pickett (1980) from horizons identified by him as being late Lochkovian, pesavis Zone age (but now referred to the sulcatus Zone), by having fewer striations on the main cusp of the elements - up to six compared to approximately twelve. Both these forms are easily distinguished from Oul. astriatus sp. nov. which has no striations on the main cusp of all elements of the apparatus.

Other occurrences of Oul. paucistriatus in Australia include those at Boola Quarry, Victoria, from horizons dated as sulcatus and kindlei zones (Mawson \& Talent 1994) and from the Lilydale Limestone, Victoria, from horizons dated as kindlei and pireneae zones (Wall et al. 1995).

\section{Oulodus elegans detorta? (Walliser, 1964)}

Figure 30M

Remarks. - A single Sb element was obtained from Myola 2. It shows a small denticle adjacent to the cusp on one process similar to the alternating denticle size seen in Oul. elegans detorta, but the specimen is very poorly preserved and the identification must be considered provisional.

\section{Oulodus? Apparatus A}

Figure 14G-M

Remarks. - These elements, having a morphology that suggests an association within the same apparatus, are tentatively placed within Oulodus. The denticles are not always separated by "U-shaped" spaces along processes nor are they always well rounded in cross section. Oulodus? Apparatus $\mathrm{A}$ is distinguished by its evenly distributed, well-packed, sharp, relatively tall, pointed denticles on the bars of all elements. The processes are thickened close to the base of the denticles, which may be compressed in cross-section. There is a prominent "lip" over the basal cavity of the Sa element (Fig. 14I, J) and possibly the Sc element (Fig. 14L) where the basal cavity "hood" is constricted so that it appears as a diminuitive third process.

Elements tentatively grouped together in this apparatus are similar to those illustrated by Drygant \& Szaniawski (2012, fig. 8A-M) as "unassigned taxa" from the Lochkovian to Pragian Ivanye Formation of Podolia. In particular, the pronounced basal cavity extension in the $\mathrm{Sa}$ element (Fig. 14I, J) is similar to that developed in the $\mathrm{Sb}$ element (Drygant \& Szaniawski 2012, fig. 8E). The Pb element of Oulodus? Apparatus A (Fig. 14H), however, has an angled lower margin unlike the gently curved lower margin of the $\mathrm{Pb}$ elements illustrated by Drygant \& Szaniawski (2012, fig. 8A, B, D). One Sa element of Oulodus? Apparatus A (Fig. 14I) also has some similarities to an element illustrated by Drygant (2010, pl. 22, fig. 20) as "Hibbardella sp.", such as denticulation, the small angle between processes and the thickening of the blade below the cusp. Our Sa element also has similarities to one figured by Suttner (2007, pl. 13, fig. 14) as an ?Sb element of "Apparatus A" from the Lochkovian Rauchkofel Formation, although Suttner's specimen shows much finer and more closely packed denticulation.

Oulodus? Apparatus A occurs in the upper horizons of the Booth Limestone dated as of pireneae Zone age.

\section{Oulodus? Apparatus B} Figure $14 \mathrm{~N}-\mathrm{P}$

Remarks. - A small number of oulodid elements with narrow processes are tentatively grouped into this apparatus. Denticles are separated by broad U-shaped spaces in accordance with the characteristics of the genus. The denticles are longer and finer that those of Oulodus? Apparatus A, and the basal cavity is longer and not as wide. The $\mathrm{Pb}$ elements are gently arched and twisted, as also seen in many of the elements of Aspelundia as originally defined by Savage (1985) and amended by Armstrong (1990). Certainty concerning the generic identification requires greater numbers of specimens.

These elements have been obtained from horizons of the sulcatus and kindlei zones, stratigraphically beneath those that have yielded Oulodus? Apparatus A.

Order Ozarkodina Dzik, 1976

Family Spathognathodontidae Hass, 1959

\section{Genus Amydrotaxis Klapper \& Murphy, 1980}

Type species. - Spathognathodus johnsoni Klapper, 1969.

\section{Amydrotaxis druceana (Pickett, 1980)}

Figure 15

1980 Ozarkodina druceana nom. nov.; Pickett, pp. 73-77, figs $5 \mathrm{~A}-\mathrm{W}, 6 \mathrm{~A}-\mathrm{U}, 7 \mathrm{~A}-\mathrm{C}$. See also for early synonymy.

1990 Amydrotaxis druceana (Pickett). - Bischoff \& Argent, pp. 453-454, pl. 1, figs 1-29.

1991 Amidrotaxis (sic) druceana (Pickett). - Bardashev, pp. 214-215, pl. 108, figs $1,2$. 
1992 Amidrotaxis (sic) druceana (Pickett). - Bardashev \& Ziegler, pl. 2, figs 1, 2.

1994 Amydrotaxis druceana (Pickett). - Mawson \& Talent, p. 49, fig. 10A-P.

1995 Amydrotaxis druceana (Pickett). - Wall et al., p. 378, pl. 1, figs 1-17.

1999 Amydrotaxis druceana (Pickett). - Talent \& Mawson, pl. 4, figs 10-21, pl. 5, fig. 10, pl. 8, figs 3, 5, 7, 15, pl. 11, fig. 8 .

2003 Amydrotaxis druceana (Pickett). - Farrell, pp. 129-131, pl. 4, figs 13-21, pl. 5, figs 1-9.

2003 Amydrotaxis druceana (Pickett). - Sloan, pl. 1, figs 7-9.

2005 Amydrotaxis druceana (Pickett). - Trotter \& Talent, pl. 18, figs 10, 13-18.

2008 Amydrotaxis druceana (Pickett). - Gaetani et al., p. 280 , pl. 1, fig. 3 .

Remarks. - Pickett (1980) identified the various elements of the apparatus of Amydrotaxis druceana from collections from the Rookery Limestone Member at "The Rookery", ca $35 \mathrm{~km}$ SE of Cobar. Our study accords with Pickett's (1980) reconstruction.

\section{Amydrotaxis corniculans truncus subsp. nov. Figure 16A-Q}

Holotype. - Pa element, specimen AMF 130512 (Fig. 16A, B), from MDAM 31.

Type locality and horizon. - Sample MDAM 31 from the Mountain Dam Limestone on "Marobee" station, approximately $90 \mathrm{~km}$ NW of Condobolin, central New South Wales.

Etymology. - Truncus (Latin), trunk or stump; in reference to the stubby, stump-shaped nature of most elements of the apparatus in comparison with the nominotypical subspecies.

Diagnosis. - A subspecies of Amydrotaxis corniculans having relatively low, stubby, horn-shaped denticles on most of the elements of the apparatus.

Description. - Pa element spathognathodan, straight with a single row of stubby denticles with those posterior to the basal cavity being distinctly lower, less distinct and more knob-like. Terminal denticles slightly higher than other posterior ones. Basal cavity lobes expanded at mid-length and tending to be swept forwards towards the anterior of the unit.

$\mathrm{Pb}$ element ozarkodiniform with main cusp broad and flattened. Five or six anterior denticles are blunt and stubby. Posterior denticles are ill defined if indeed present, with a low, horn-shaped knob or thickening at the posterior extremity. Basal cavity asymmetrically widened beneath the main cusp.

?M element short with high main cusp and one well-developed process; other denticles indistinct with terminal denticle knob-like. Basal cavity is well developed and similar in shape to those of $\mathrm{Pb}$ elements ( $c f$. Fig. 16Q with $16 \mathrm{~J}, \mathrm{M})$.

Symmetry transition series consists of alate, bipennate and digyrate elements, all with narrow processes bearing a few irregularly spaced, short denticles. All elements have relatively small basal cavities somewhat expanded beneath the main cusp and tapering towards the distal extremities.

Remarks. - Mawson (1986, p. 50) first recognised this species in the Windellama Limestone of southeast Australia, the diagnostic characteristic being a tiny anterior denticle preceding relatively even denticulation on the rest of the blade. Mawson postulated that the relatively symmetrical basal cavity and unfused denticles may mean that $A$. corniculans was ancestral to $A$. johnsoni. The retention of the diagnostic feature in this taxon (Fig. 16A) and the relatively symmetrical but restricted basal cavity in comparison with the Windellama taxon, lead us to interpret this as a new subspecies of $A$. corniculans.

The novelty of Amy. corniculans truncus lies in the nature of the stubby denticles and the deep, clearly defined basal cavities present on each element of the apparatus.

\section{Amydrotaxis sp. A}

Figure 16R-U

Remarks. - Pa elements are long (up to $2.1 \mathrm{~mm}$ ) and in lateral view have three slightly higher anterior denticles. Denticles in the mid-section of the unit appear fused and, in the posteriormost quarter, decline to the base at an angle of approximately $45^{\circ}$. In upper view, expansion of the basal cavity occurs at a point anterior to mid-length of the blade. The outer basal cavity lobe is rounded to oval in shape and the inner lobe is more restricted and ear-shaped from its anteriormost end and may appear to be posteriorly deflected. The shape of the basal cavity is similar to that of the alpha morphotype of $A$. johnsoni (Klapper) but lacks the laterally extensive platform development seen in the latter.

\section{Genus Ancyrodelloides Bischoff \& Sannemann, 1958}

Type species. - Spathognathodus trigonicus Bischoff \& Sannemann, 1958.

Remarks. - Murphy \& Valenzuela-Ríos (1999) split the generic Ancyrodelloides concept based on whether terraces 
developed on the basal cavity lobes are ornamented or not. Those with unornamented terraces were the basis of the genus Lanea, regarded as ancestral to those with ornamented terraces that were retained in Ancyrodelloides.

The Pragian forms with unornamented terraces obtained by Mawson \& Talent (1994) from Boola and Tyers in Victoria were interpreted by Murphy \& Valenzuela-Ríos (1999) as a heterochronously convergent form superficially similar in morphology to Lanea. More recently, Corriga et al. (2014, p. 192) pointed out that the diagnoses of Ancyrodelloides and Lanea are not clear and overlap each other. Furthermore, they raised doubts about the assignment of species to each genus by Slavík (2011), and indicated that full reconstructions are needed to resolve the differing interpretations. While we acknowledge that the phyletic scenario proposed by Murphy \& Valenzuela-Ríos (1999) may well be valid, we can only work with the morphology of the collections available to us in this study and therefore choose to retain the original nomenclature without prejudice.

\section{Ancyrodelloides omus Murphy \& Matti, 1982} Figure $21 \mathrm{~A}-\mathrm{F}$

1982 Ancyrodelloides omus Murphy \& Matti; pp. 16-20, text-fig. 5a, b, pl. 2, figs 14, 18-29.

For synonymy prior to 1990, see Klapper in Ziegler (1991).

1990 Ancyrodelloides omus $\alpha$ morphotype Murphy \& Matti. - García-López et al., pl. 1, figs 11-14.

1994 Ancyrodelloides omus Murphy \& Matti. - Mawson \& Talent, pp. 51-53, fig. 12A-N.

1994 Ancyrodelloides omus alpha Murphy \& Matti. Valenzuela-Ríos, pp. 37-38, pl. 1, figs 5, 6.

1999 Ancyrodelloides omus Murphy \& Matti. - Talent \& Mawson, pl. 5, figs 6-9, pl. 7, fig. 13, pl. 8, fig. 4, pl. 12, fig. 10.

2002 Lanea omoalpha Murphy \& Valenzuela-Ríos. García-López et al., pl. 3, fig. 11.

2004 Lanea omoalpha Murphy \& Valenzuela-Ríos. - Farrell, p. 976, pl. 8, figs 12, 13.

2004 Lanaea aff. omoalpha Murphy \& Valenzuela-Ríos. - Slavík \& Hladil, p. 147, pl. 1, fig. 10.

2005 Lanea omoalpha Murphy \& Valenzuela-Ríos. Valenzuela-Ríos et al., pl. 1, figs e, f.
2007 Lanea omoalpha Murphy \& Valenzuela-Ríos. - Suttner, pp. 31-32, pl. 19, figs 5, 8, 10.

2008 Ancyrodelloides omus Murphy \& Matti. - Kim et al., pl. 16, figs 1, 3, 5 .

2012 Lanea omoalpha Murphy \& Valenzuela-Ríos. Corriga et al., fig. 5.5, 5.6.

2012 Lanea omoalpha Murphy \& Valenzuela-Ríos. Drygant \& Szaniawski, fig. 13M, P, T.

2013 Lanea omoalpha Murphy \& Valenzuela-Ríos. Mavrinskaya \& Slavík, fig. 5A-C.

Remarks. - Murphy \& Matti (1982) argued that Ancyrodelloides was derived from Ozarkodina remscheidensis, and that their new species Anc. omus was the oldest representative of Ancyrodelloides. They claimed Anc. omus was restricted to low in the Early Devonian (latest eurekaensis Zone to delta Zone, an age later confirmed by Klapper (in Ziegler 1991). Chlupáč et al. (1985, fig. 17), however, had previously shown that in the Barrandian and Carnic Alps "Anc." omus first appeared late in the early Lochkovian and extended through to early in the late Pragian. Subsequently, Klapper (in Ziegler 1991) included in the synonymy of "Anc." omus specimens from Tyers in Victoria first illustrated and described by Philip (1965) as "Spathognathodus steinhornensis". From two sections in the Tyers area, Mawson \& Talent (1994) obtained over 450 specimens of this species and confirmed that they occur in horizons dated as sulcatus and kindlei zones. Mawson \& Talent (1994, p. 51) also recorded reservations as to the generic placement of the species based on persistence of its open basal cavity.

In the area under study, Anc. omus occurs in horizons of sulcatus Zone age in the MDAM section, and of kindlei Zone age in the BOOTH section.

\section{Genus Eognathodus Philip, 1965}

Type species. - Eognathodus sulcatus Philip, 1965.

Remarks. - Philip's original diagnosis of Eognathodus was based on Pa elements from the Tyers area, eastern Victoria. Both Philip (1965) and Klapper et al. (1981) emphasized that Eognathodus was characterised by a double row of nodes on its upper surface with a depression or trough between the rows. As further collections were made from the

Figure 15. Amydrotaxis druceana (Pickett, 1980). A-D - upper, lateral, lower and enlarged upper views respectively of Pa element MMMC 4494 from MDAM 31. E, F - upper and lateral views of Pa element MMMC 4495 from MDAM 28. $\bullet$ G lateral view of Pa element MMMC 4496 from MDAM25. $\bullet \mathrm{H}, \mathrm{I}-$ upper and lateral views of Pa element MMMC 4497 from MDAM 30. $\bullet-\mathrm{L}-$ upper, lateral and lower views of Pa element MMMC 4498 from MDAM 37. $\mathrm{M}, \mathrm{N}$ - lateral and lower views of Pb element MMMC 4499 from MDAM 15. $\bullet \mathrm{O}, \mathrm{P}-$ lateral and lower views of $\mathrm{Pb}$ element MMMC 4500 from MDAM 12. $\bullet \mathrm{Q}$ - lateral view of Pb element MMMC 4501 from MDAM 9. $\bullet \mathrm{R}-$ lateral view of Pb element MMMC 4502 from MDAM 15. $\bullet$ - lateral view of Pb element MMMC 4503 from MDAM 37. $\bullet$ - lateral view of Sc element MMMC 4504 from MDAM 15. $\bullet$ U, V - lateral and lower views of M element MMMC 4506 from MDAM 12. Scale bar $=0.1 \mathrm{~mm}$ except in D. 


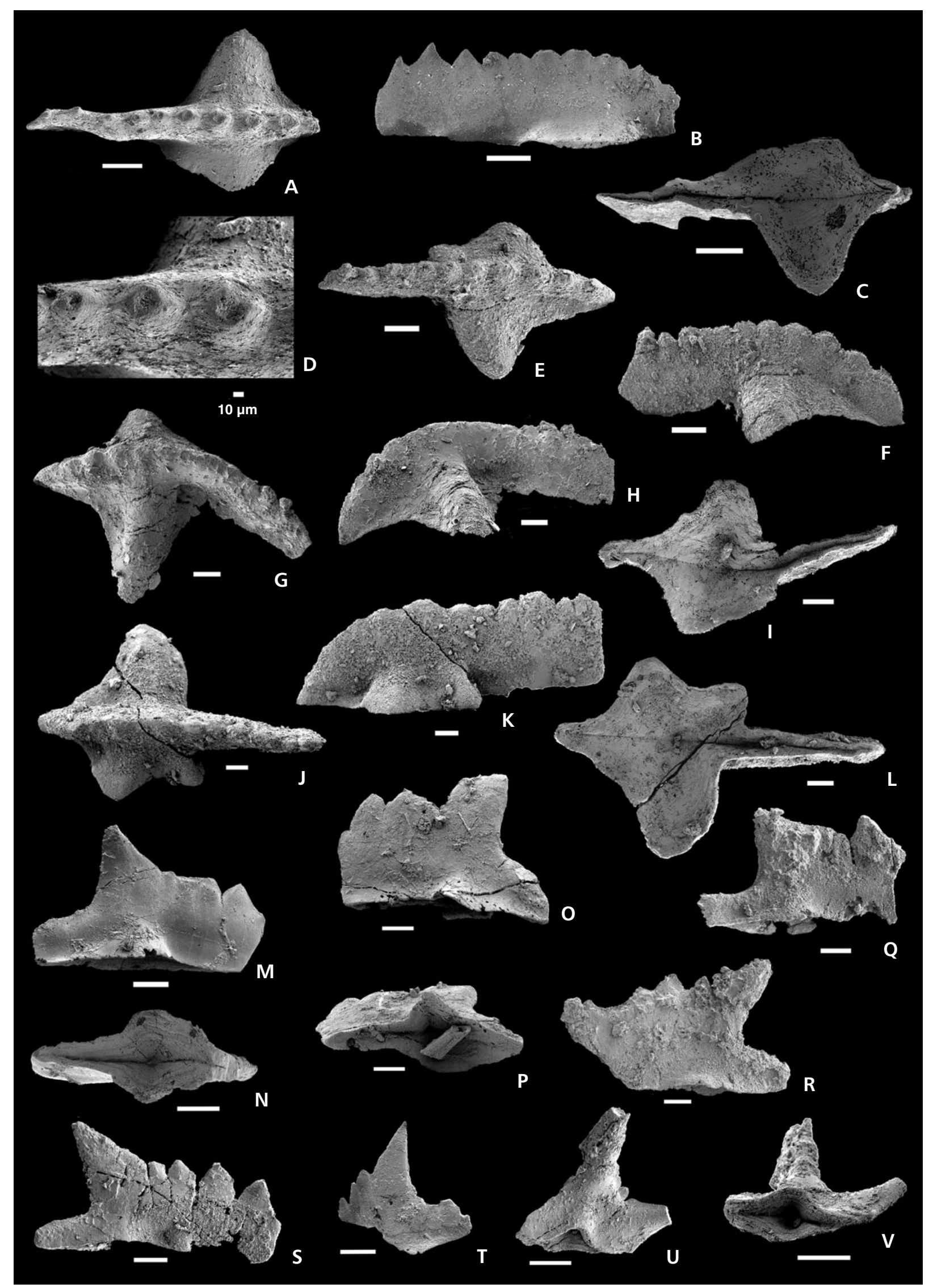


same time slice it became evident that there were variations to the "double row of nodes". In amending Philip's diagnosis of Eognathodus, Murphy et al. (1981, p. 765) referred to "... a sulcus between rows of nodes or ridges, or an irregular pattern of nodes and ridges on the crest of the P unit". Earlier, Lane \& Ormiston (1979, p. 47) noted that some specimens had developed "...two parallel white-matter ridges, the distinction of the original individual denticles being lost completely". What is important is that the introduction of two rows of denticles or two parallel ridges with a sulcus between is the novel feature that distinguished an eognathodontan from an ozarkodinan. Such variation in a genus, however, suggests that more than one pathway of evolution is likely for Eognathodus, in a similar way as suggested for Polygnathus by Klapper \& Johnson (1975) and Mawson (1987).

Debate on the derivation of Eognathodus is not new; its origin and progenitors have often been discussed (e.g. Mawson 1998). Based on collections from the Salmontrout River area, east-central Alaska, Lane \& Ormiston (1979) suggested that eognathodontans arose from an ozarkodinan stock via their new species Oz. selfi. Murphy et al. (1981, p. 770) contended that the earliest form of the genus, Eo. sulcatus eta morph, "is characterized by a thick blade with a rounded crest on which bluntly terminated denticles are irregularly arranged...". In justifying their phyletic interpretation of the development of Eognathodus sulcatus from the pandora stock, Murphy et al. (1981, p. 753) suggested that Ozarkodina selfi is a juvenile of Eo. sulcatus rather than a separate species that gave rise to the Eo. s. juliae $\rightarrow$ Eo. s. kindlei lineage. Their principal arguments for such suppression of Lane and Ormiston's species were its small size and the coincidental stratigraphic range of $E o$. sulcatus ssp. and $\mathrm{Oz}$. selfi. It is, however, shown herein (Table 3) that two new subspecies of $O z$. selfi occur in faunas dated as pireneae Zone, such as the specimens in limestones from Stoney Tank, whereas subspecies of Eo. sulcatus do not occur in faunas dated as younger than kindlei Zone, for example in the limestones from the Manuka Anticline. This is contrary to the coincident age argument given by Murphy et al. (1981).

Evidence from our study shows that, taking into consideration additional morphological features of $\mathrm{Oz}$. self $i$ and Eo. sulcatus, such as the shape of the basal cavity, the lateral profile and the nature of the denticles, several subspe- cies with a range of morphologies can be identified within each species. The new subspecies of Eo. sulcatus are based on the shape of the basal cavity and the nature of the denticles along the crest of the blade.

From their studies of conodonts from Early Devonian sequences in central Nevada, Murphy \& Matti (1982, p. 8) discriminated a pi morph of Ozarkodina pandora based on the Pa element having non-tuberculate platform lobes and a spear-shaped basal cavity that "occupies a little more than half of the element". Because of the distinct narrow, spear-shaped basal cavity, it is suggested that this form may have been the origin of the lineage $O z$. pandora pi morph $\rightarrow$ Oz. selfi lanceola $\rightarrow$ Eo. sulcatus sicatus.

\section{Eognathodus sulcatus Philip, 1965}

Remarks. - It is generally accepted (e.g., Philip 1965, p. 99; Sweet 1988) that Eognathodus sulcatus has two rows of irregular nodes arranged laterally along the unit, producing a trough or sulcus in between. In contrast, Ozarkodina has a single row of denticles arranged longitudinally along the crest of the Pa element (Klapper 1977, p. 111). The concept of species of Eognathodus with a single row of denticles, irregularly arranged and at times irregularly shaped, was introduced by Murphy et al. (1981, p. 770) for E. sulcatus eta morph, and Murphy (1989, p. 62) for the subspecies E. s. eosulcatus. Weddige (1987) described the evolution of Eognathodus sulcatus from Ozarkodina pandora in terms of the nodes on the crest of the upper platform broadening transversely, becoming two humped, then separating to form a trough or sulcus.

Murphy (1989, p. 62, fig. 1) in his diagnosis of E. s. eosulcatus pointed to the unaligned nature of the denticles as being the defining characteristic of the subspecies, inferring that further evolutionary change and divergence of the denticles led to formation of the sulcus. Murphy (1989) seemed to differ from Weddige's (1987) hypothesis for sulcus formation; both interpretations were supported with their respective specimen illustrations.

Eognathodus sulcatus lanei subsp. nov. illustrates a third way of deriving an eognathodontan from an ozarkodinan by the dimpling of denticles leading to short elongate troughs that eventually developed into two smooth ridges on either side of the sulcus.

Figure 16. A-Q - Amydrotaxis corniculans truncus subsp. nov. $\bullet \mathrm{A}, \mathrm{B}-$ lateral and upper views of Pa element, holotype MMMC 4507 from MDAM 34. $\bullet$ C, D - lateral and upper views of Pa element MMMC 4508 from MDAM 4. • E, F - lateral and lower views of Pb element MMMC 4509 from MDAM 31. $\bullet \mathrm{G}, \mathrm{H}-$ lateral and lower views of Pb element MMMC 4510 from MDAM 4. $\bullet \mathrm{I}-\mathrm{K}-$ lateral, oblique lower and upper views of Pb element MMMC 4511 from MDAM 24. • L, M - lateral and lower views Pb element MMMC 4512 from MDAM 12. $\mathrm{N}-$ lateral view of Sb element MMMC 4513 from MDAM 4. $\bullet$ O - lateral view of Sc element MMMC 4514 from MDAM 4. $\bullet$ P, Q - lateral and upper views of ?M element MMMC 4515 from MDAM 18. $\bullet$ R-U - Amydrotaxis sp. A. $\bullet$ R, S - lateral and upper views of Pa element MMMC 4516 from MDAM 28 . $\bullet$ T, U - upper and lower views of Pa element MMMC 4517 from MDAM 19. Scale bar $=0.1 \mathrm{~mm}$. 


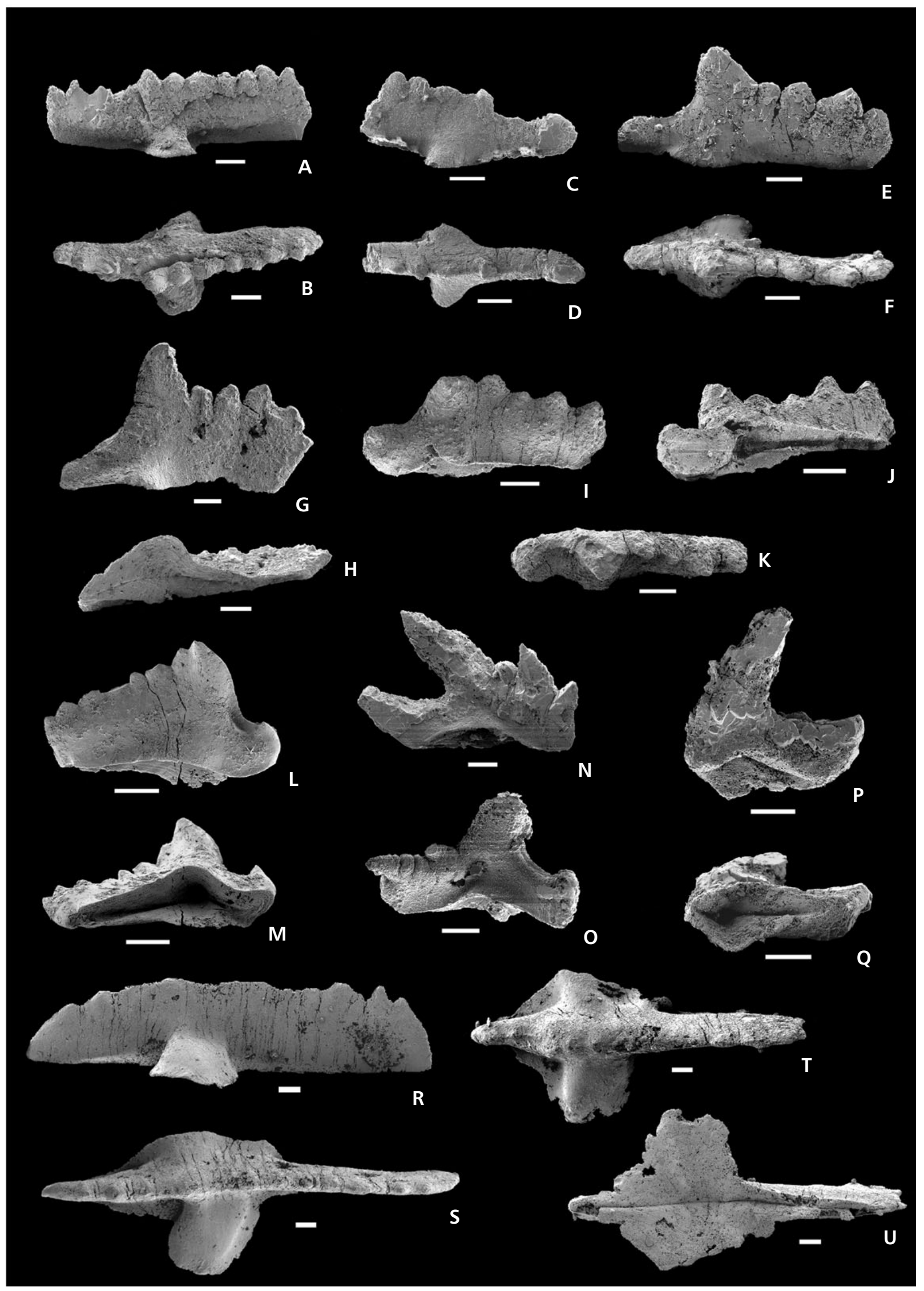


Although no specimens of Eo. sulcatus juliae (Lane \& Ormiston, 1979) were obtained from acid-insoluble residues processed for our study, we consider that one of the specimens illustrated as this subspecies by Lane \& Ormiston $(1979$, pl. 3, figs 22,23$)$ actually belongs to Ozarkodina selfi lanceola (see below).

\section{Eognathodus sulcatus lanei subsp. nov.} Figures 17A-M, 18, 32E-G, J

?1980 Ozarkodina cf. eurekaensis Klapper \& Murphy. Pickett, p. 77, fig. 8C (only).

2003 Ozarkodina pandora zeta morphotype Murphy et al. - Farrell, pp. 136-137, pl. 7, figs 15-19.

Holotype. - Pa element, specimen MMMC 4518 (Fig. 17A-D), from MDAM 11.

Type locality. - Sample MDAM 11 from the Mountain Dam Limestone Member on "Marobee" station, approximately $90 \mathrm{~km} \mathrm{NW}$ of Condobolin, central New South Wales.

Etymology. - Named for H. Richard Lane who with Allen R. Ormiston first recognised the development of the two smooth, parallel ridges on the crest of some forms of Eognathodus sulcatus (Lane \& Ormiston 1979, p. 47).

Diagnosis. - A subspecies of Eognathodus sulcatus with Pa elements having a sulcus bounded on either side by smooth ridges situated in the mid third of the unit and having a large, wide, oval basal cavity occupying two-thirds to three-quarters of the unit.

Description. - The Pa element is characterized by the central third of the denticles appearing to be completely fused, forming a relatively deep sulcus mid-blade bounded by parallel ridges and extending slightly towards the posterior end. In upper view, the crest, at times, can be curved or sinuous although the sulcus remains straight. The blade is relatively broad, short and high. In lateral view, the posterior margin of the blade slopes relatively steeply as the two to four denticles decline in height. Close to its lower margin, just above the basal cavity, the blade may appear to be pinched, producing a longitudinal bulge and groove (Fig. 17C, F, I, K). Five or six laterally compressed anterior denticles of medium height are fused almost to the top, curving at their tips towards the posterior. The basal cavity is broad, oval in shape and occupies the posterior two-thirds to three-quarters of the unit.

Remarks. - Eognathodus sulcatus lanei is characterised by its relatively deep sulcus bounded by two smooth ridges with no sign at the surface of denticles associated with the sulcus. A specimen from B 11D, photographed with reflected light and dark field and with transmitted light, shows "submerged" denticles (Fig. 18). The two smooth ridges derived from the rows of denticles are now seen as incipient individual denticles beneath the surface of the specimen. This is in accord with the observations by Lane (in Lane \& Ormiston 1979). Eognathodus sulcatus lanei varies from other subspecies of Eo. sulcatus in having a more rounded and extensive basal cavity occupying up to threequarters the length of the unit, as well as in the smooth ridges bounding the trough.

The specimen from the White Tank Limestone illustrated by Pickett (1980, fig. 8C) is tentatively included in the synonymy. It has sulcate upper element morphology with two distinct ridges developed over a broad basal cavity; however, judging from the illustration the ridges may not be continuous.

\section{Eognathodus sulcatus sicatus subsp. nov.} Figure 17N-V

?1994 Eognathus sulcatus Philip. - Mawson \& Talent, pp. 53-55, fig. 8A, B (only).

Holotype. - $\mathrm{Pa}$ element, specimen MMMC 4524 (Fig. 17N-O), from sample B 11C.

Type locality and horizon. - Sample B 11C from the Booth Limestone $c a 700$ m NNW of Beulah Tank on "Manuka" station.

Etymology. - Sica (Latin), a dagger, in reference to the narrow, dagger- or spear-like shape of the basal cavity.

Diagnosis. - A subspecies of Eognathodus sulcatus with $\mathrm{Pa}$ elements having a narrow sulcus bounded on either side by smooth ridges situated in the mid-third of the

Figure 17. A-M - Eognathodus sulcatus lanei subsp. nov. • A-D - upper, oblique, oblique lateral, lateral and lower views of Pa element, holotype MMMC 4518 from MDAM 11. • E, F - upper and lateral views of Pa element MMMC 4519 from MDAM 5. • G, H - lateral and upper views of Pa element MMMC 4520 from MDAM 13. • I, J - lateral and upper views of Pa element MMMC 4521 from MDAM 15. $\bullet$ K, L - lateral and upper views of Pa element MMMC 4522 from MDAM 24. $\bullet$ M - upper view of Pa element MMMC 4523 from MDAM 15. $・$ N-V - Eognathodus sulcatus sicatus subsp. nov. $\bullet$ N, O - lateral and upper views of Pa element, holotype MMMC 4524 from B 11C. $\bullet$ P - upper view of Pa element MMMC 4525 from MDAM 10. $\bullet \mathrm{Q}, \mathrm{R}$ - lateral and upper views of Pa element MMMC 4526 from MDAM 12. $\bullet$ - upper view of Pa element MMMC 4527 from MDAM 15. $\bullet$-V - lateral, upper and enlarged upper view of Pa element MMMC 4528 from MDAM 35. Scale bar $=0.1 \mathrm{~mm}$. 


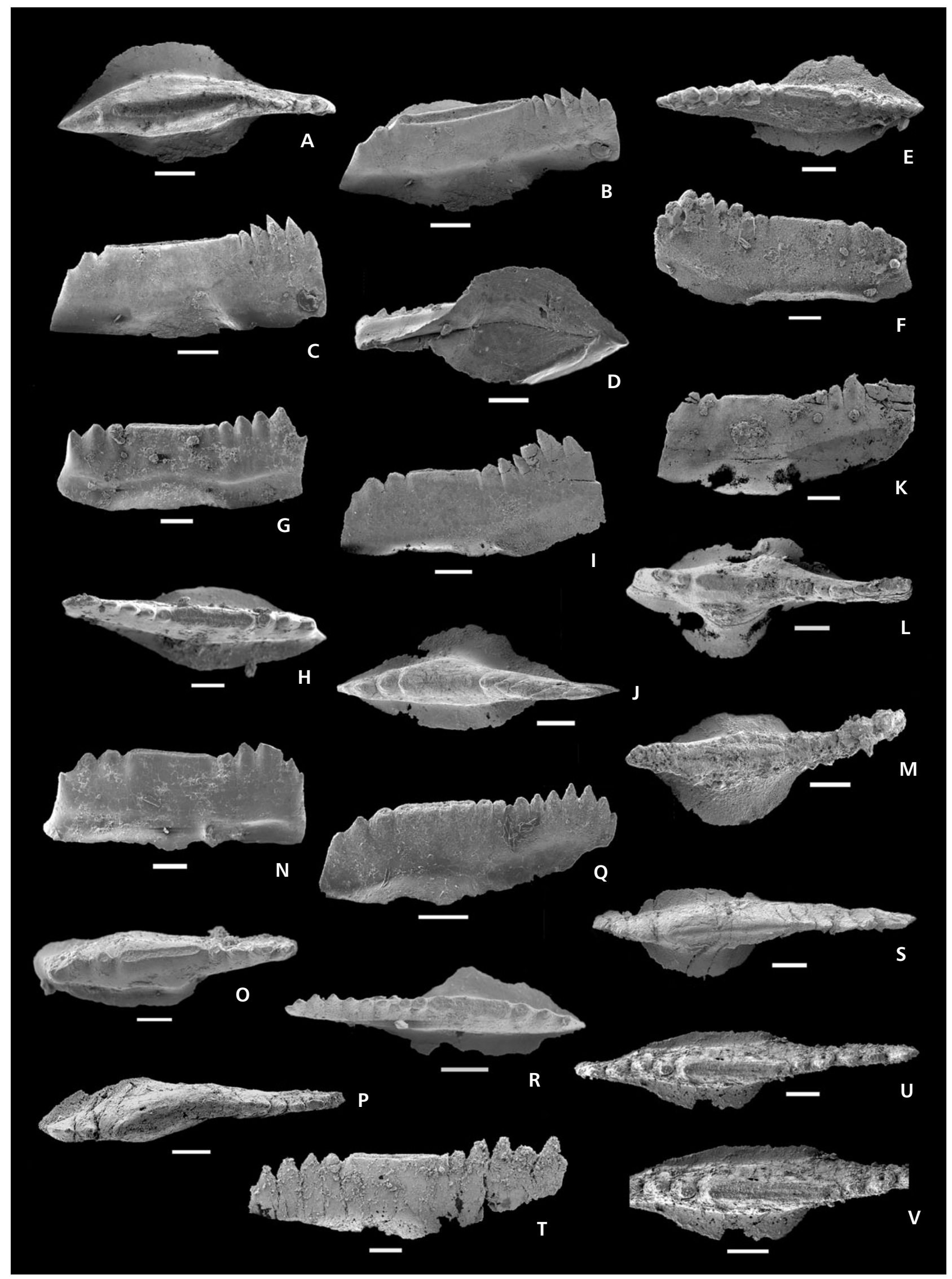


unit and having a narrow dagger- or spear-shaped basal cavity.

Description. - The Pa element is characterized by having a relatively long, low blade. Approximately the central third of the denticles appear to be fused forming a sulcus mid-blade bounded by smooth, parallel ridges. Three to five discrete, triangular anterior denticles, higher than the rest of the unit, tend to form a low fan; three or four discrete, triangular posterior denticles decrease in height towards the posterior extremity of the unit. In upper view, the blade is straight but becomes curved in gerontic forms. Five or six laterally compressed anterior denticles of medium height are fused almost to the top, curving at their tips towards the posterior. The basal cavity is narrow, dagger- or spear-shaped and occupies the posterior two-thirds of the unit.

Remarks. - Eognathodus sulcatus sicatus is characterised by its narrow sulcus bounded by two smooth ridges, and its narrow, spear-shaped basal cavity. Because of its narrow, spear-shaped basal cavity, it appears to belong to a lineage involving $\mathrm{Oz}$. pandora pi morph $\rightarrow O z$. selfi lanceola $\rightarrow$ Eo. sulcatus sicatus as discussed above. Despite the small number of specimens available, the form is distinctive.

\section{Genus Ozarkodina Branson \& Mehl, 1933}

Type species. - Ozarkodina typica Branson \& Mehl, 1933.

Remarks. - Murphy et al. (2004), citing in part historical evidence on the development of conodont taxonomy, argued for reconsideration of the generic concept of Ozarkodina, in particular those taxa spanning the Silurian-Devonian boundary, by splitting it into the genera Wurmiella, Zieglerodina and Genus "W", and retaining the concept of Ozarkodina only for taxa associated with the type species. The viability of such a reconfiguration has been discussed elsewhere (e.g. Suttner 2009, Corriga \& Corradini 2009). Cladistic studies such as that by Donoghue et al. (2008) support the contention of a polyphyletic nature of this group. Our study is primarily biostratigraphic in nature and our faunas add nothing to the generic-level taxonomic discussions about Ozarkodina. We therefore retain the original genus concept without prejudice, but recognize the potential for subdivision of this group.

\section{Ozarkodina buchanensis (Philip, 1966)}

Figure 19A-N

1966 Spathognathodus steinhornensis buchanensis $\mathrm{n}$. subsp.; Philip, pp. 450-451, pl. 2, figs 1-15 (non figs 16-28).
1987 Ozarkodina buchanensis (Philip). - Mawson, pp. 282-286, pl. 37, figs 1-20 (see also for further synonymy).

1992 Ozarkodina buchanensis (Philip). - Mawson et al., figs $9 \mathrm{I}, \mathrm{J}, 12 \mathrm{~K}-\mathrm{O}$.

1995 Ozarkodina buchanensis (Philip). - Colquhoun, pl. 1, figs 12,15 .

1998 Ozarkodina buchanensis (Philip). - Kozur, pl. 1, fig. 16.

1999 Ozarkodina buchanensis (Philip). - Talent \& Mawson, pl. 8, fig. 15.

2003 Ozarkodina buchanensis (Philip). - Sloan, pl. 1, figs 13-15.

2003 Ozarkodina buchanensis (Philip). - Mawson \& Talent, pl. 1, fig. 20.

Remarks. - Ozarkodina buchanensis, although resembling in many ways $O z$. remscheidensis, can be easily distinguished from the latter by having a shorter, higher blade and a more centrally situated basal cavity of the Pa element.

Klapper \& Philip (1972) described the apparatus of Oz. buchanensis as a Type 1 apparatus, basing their reconstruction on material collected by Philip (1966). In the Buchan area of Victoria it was demonstrated that the youngest occurrence of $\mathrm{Oz}$. buchanensis was in the dehiscens Zone (Mawson 1987), but more recently it has been found in horizons dated as perbonus Zone (Mawson et al. 1992). At Loyola, Victoria, Cooper (1973) recorded this species as occurring with Polygnathus pireneae, a species indicative of the pireneae Zone, the last, poorly defined interval of the Pragian. Mawson et al. (1992) documented the occurrence of $\mathrm{Oz}$. buchanensis in pre-dehiscens horizons low in the Buchan Caves Limestone in eastern Victoria. Its range thus appears to be from the pireneae Zone to the perbonus Zone.

\section{Ozarkodina sp. cf. Oz. buchanensis (Philip, 1966)} Figure 190-Q

Remarks. - A few ozarkodinans identified from the area of study are very similar to $O z$. buchanensis in having a centrally located basal cavity but differ from typical members of the species by having denticles that vary more in size.

\section{Ozarkodina confluens (Branson \& Mehl, 1933)} Figure 30O-Q

1995 Ozarkodina confluens (Branson \& Mehl). - Simpson \& Talent, pp. 142-146, pl. 7, figs 26, 27, pl. 8, figs 1-6 (contains extensive synonymy).

1995 Ozarkodina confluens (Branson \& Mehl). - Miller, pl. 1, fig. 11. 
Figure 18. Eognathus sulcatus lanei subsp. nov., specimen MMMC 4694 from the Booth Limestone, locality B11D; photomicrographs taken with an optical microscope, showing denticles buried within the body of the conodont element ( $c f$. Fig. 17A-D). - A - image taken with reflected light and dark field, $\times 120 . \cdot \mathrm{B}-$ image taken with reflected light and dark field, $\times 320 . \bullet \mathrm{C}-$ image taken with transmitted light, $\times 200$.

A

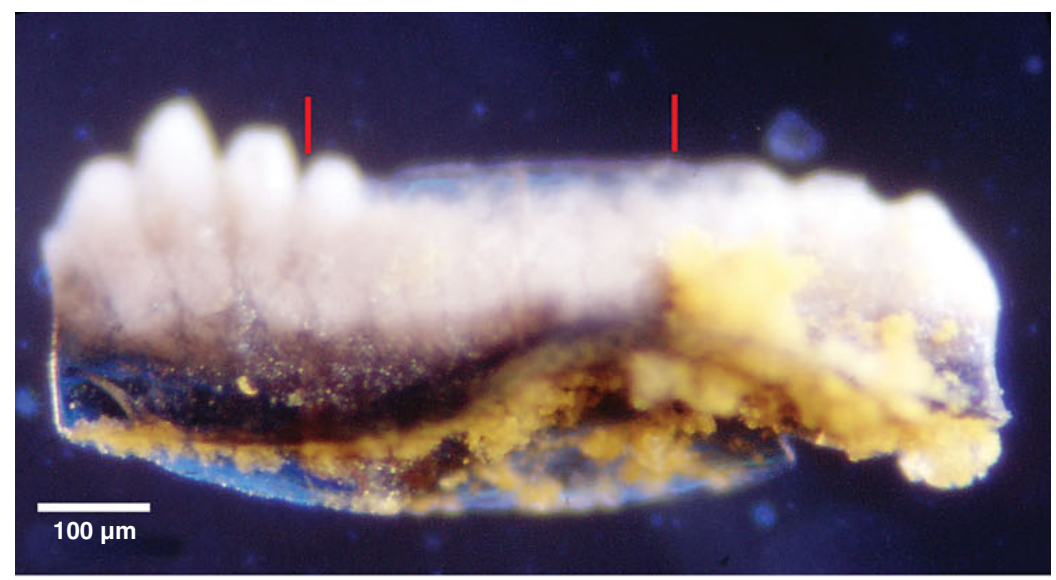

B
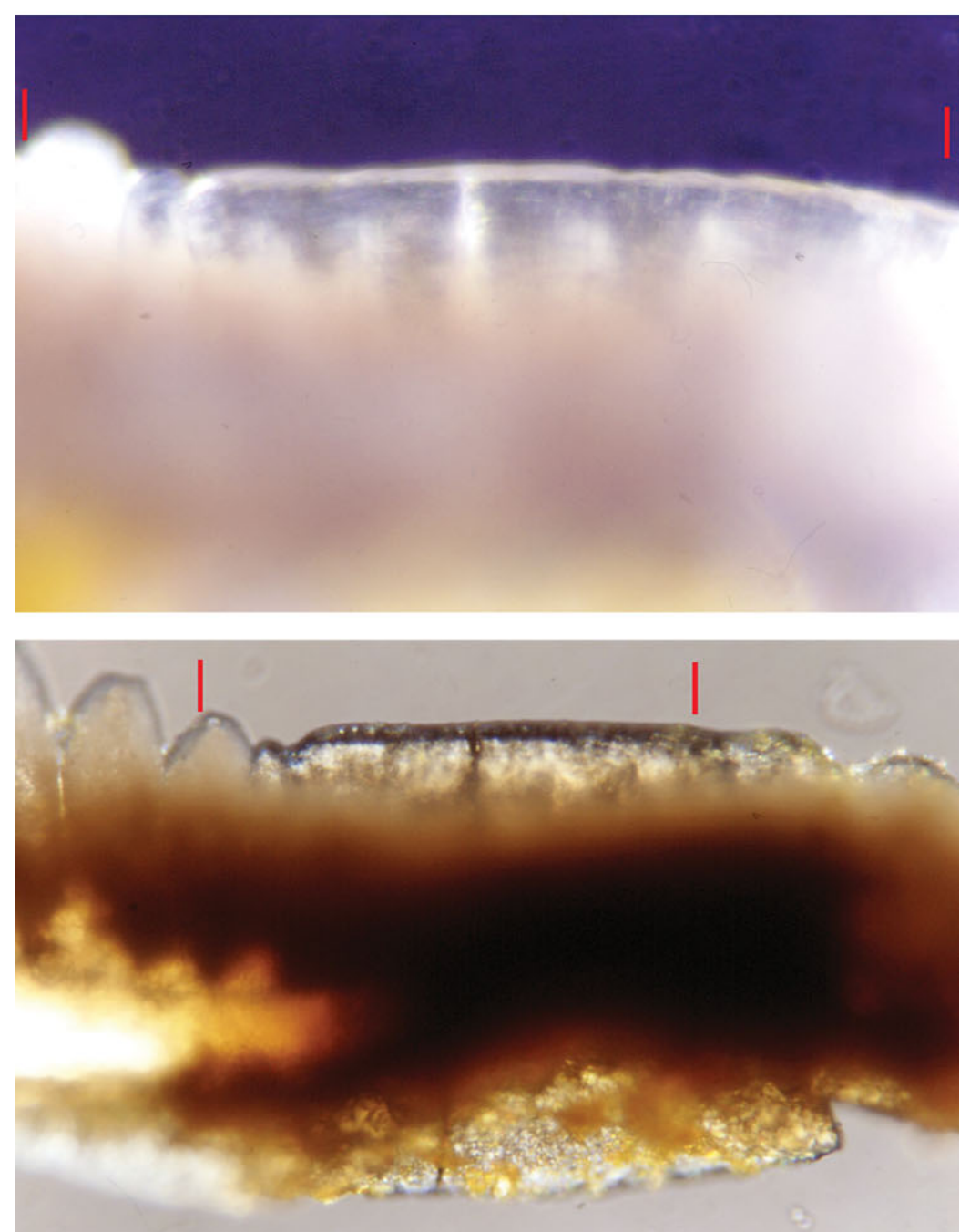

1998 Ozarkodina? confluens (Branson \& Mehl). - Percival, fig. 3.17.

1998a Ozarkodina confluens (Branson \& Mehl). - Corradini et al., pl. 3.3.1, fig. 9 .

1998b Ozarkodina confluens (Branson \& Mehl). - Corradini et al., pl. 1.3.1, fig. 2 .
1998 Ozarkodina confluens (Branson \& Mehl). - Männik \& Małkowski, pl. 2, fig. 19.

1998 Ozarkodina confluens (Branson \& Mehl). - Ferretti et al., pl. 2.2.2, fig. 3.

1998 Ozarkodina confluens (Branson \& Mehl). - Serpagli et al., pl. 1.2.2, fig. 2 . 
1999 Ozarkodina confluens (Branson \& Mehl). - Viira, pl. 2, figs 5-12, pl. 3, figs 10-12.

2004 Ozarkodina confluens (Branson \& Mehl). - Farrell, pp. 968-970, pl. 8, figs 1-7.

2004 Ozarkodina typica Branson \& Mehl. - Murphy et al., fig. 2.1-2.15.

2006 Ozarkodina confluens (Branson \& Mehl). - Farrell, fig. $6 \mathrm{G}-\mathrm{J}$.

2009 Ozarkodina confluens (Branson \& Mehl). - Corriga \& Corradini, fig. 4L, M.

2009 Ozarkodina confluens (Branson \& Mehl). - Corriga et al., pl. 2, fig. 5 .

2009 Ozarkodina confluens (Branson \& Mehl). - Männik et al., fig. 10a-c, e, f.

?2010 Ozarkodina confluens (Branson \& Mehl). - Corradini \& Corriga, pl. 3, figs 22, 23.

2010 Ozarkodina typica Branson \& Mehl. - Slavík et al., fig. $5 \mathrm{~A}-\mathrm{Z}$.

2012 ?Ozarkodina typica Branson \& Mehl. - Drygant \& Szaniawski, fig. $11 \mathrm{U}$.

2012 Ozarkodina confluens (Branson \& Mehl). - Corradini \& Corriga, fig. 6L.

2014 Ozarkodina confluens (Branson \& Mehl). - Corriga et al., p. 196, fig. 6B, C.

Remarks. - Pa elements obtained closely resemble the alpha morphotype of this species (Klapper \& Murphy 1975) but also show some characteristics of the beta morphotype. The denticles are mostly narrow and generally erect although some are slightly inclined posterior to the cusp. They are very similar to elements from the crispa Zone fauna at Cowombat Flat (Simpson et al. 1993). Simpson \& Talent (1995) provided an extensive discussion of this species. Specimens illustrated by Corradini \& Corriga (2010, pl. 3, figs 22, 23) are only tentatively included in the above listing because the $\mathrm{Pa}$ element has a lateral profile more like Oz. martinsonni auriformis Simpson, diagnosed by the nature of the basal cavity which is unclear in their illustration.

\section{Ozarkodina crispa (Walliser, 1964)}

Figure 30R-V

1995 Ozarkodina crispa (Walliser). - Simpson \& Talent, p. 146, pl. 8, fig. 15 (includes extensive synonymy).
1995 Ozarkodina crispa (Walliser). - Miller, pl. 3, figs 1, $2,4,5$.

1998b Ozarkodina crispa (Walliser). - Corradini et al., pl. 1.3.1, figs 4-6.

1999 Ozarkodina crispa (Walliser). - Viira, pl. 2, figs 1, 2.

2009 Ozarkodina crispa (Walliser). - Corriga \& Corradini, fig. 4G, $\mathrm{H}$.

2009 Ozarkodina crispa (Walliser). - Corriga et al., pl. 2, fig. 4.

2010 Ozarkodina crispa (Walliser). - Corradini \& Corriga, p. 245, pl. 3, figs 20, 21.

2010 Ozarkodina crispa (Walliser). - Wang \& Aldridge, p. 88, pl. 22, figs 6-19.

2012 Ozarkodina crispa (Walliser). - Corradini \& Corriga, fig. $6 \mathrm{C}, \mathrm{D}$.

2012 "Ozarkodina" crispa (Walliser). - Slavík \& Carls, figs 4R, 5B, C, F, H-J, L, P.

2013 Ozarkodina crispa (Walliser). - Wang, pp. 115-116, pl. 35, figs 6-19, pl. 47, figs 1-20.

Remarks. - Pa elements obtained in this study show the typical morphology of the species with a broad but asymmetrically flared basal cavity, denticles fused into a solid ridge in the central area of the blade, with some specimens showing the development of a narrow furrow in this region on the upper surface of the element. These closely resemble the $\mathrm{Pa}$ elements from Cowombat Flat (Simpson et al. 1993).

Simpson \& Talent (1995, p. 158) provided extensive discussion on the relationship between this taxon and Wenlock taxa such as Ozarkodina saggita.

\section{Ozarkodina eberleini Savage, 1977}

Figure 21G-I

1977 Ozarkodina eberleini n. sp.; Savage, p. 281, pl. 1, figs 24-32.

1984 Ozarkodina eberleini Savage. - Savage \& Gehrels, pp. 1423-1424, pl. 2, figs 19-22.

Remarks. - Ozarkodina eberleini is characterized by having three groups of two or three higher denticles at the anterior, middle and posterior of the blade and a small, fairly restricted basal cavity beneath the middle group of higher denticles. Savage (1977) showed this species to occur in

Figure 19. A-N-Ozarkodina buchanensis (Philip, 1966). A, B - lateral and lower views of Pa element MMMC 4529 from B 9. $\bullet$ C, D - lateral and lower views of Pa element MMMC 4530 from B 9. $\bullet$ E, F - lateral and upper views of Pa element MMMC 4531 from B 9. $\bullet \mathrm{G}, \mathrm{H}-$ lateral and lower views of Pa element MMMC 4532 from B 16C. $\bullet$ I, J - lateral and upper views of Pa element MMMC 4533 from GUND 1. $\bullet \mathrm{K}, \mathrm{L}-$ lateral and lower views of Pa element MMMC 4534 from B 9. $\bullet \mathrm{M}$ - lateral view of Pb element MMMC 4535 from B 16G. $\bullet \mathrm{N}$ - lateral view of Sc element MMMC 4536 from B 16L. - O-Q - Ozarkodina sp. cf. buchanensis (Philip, 1966). $\bullet$ - lateral view of Pa element MMMC 4537 from B 16G. $\bullet$ P, Q - lateral and lower views of Pa element MMMC 4538 from B 16G. Scale bar $=0.1 \mathrm{~mm}$. 


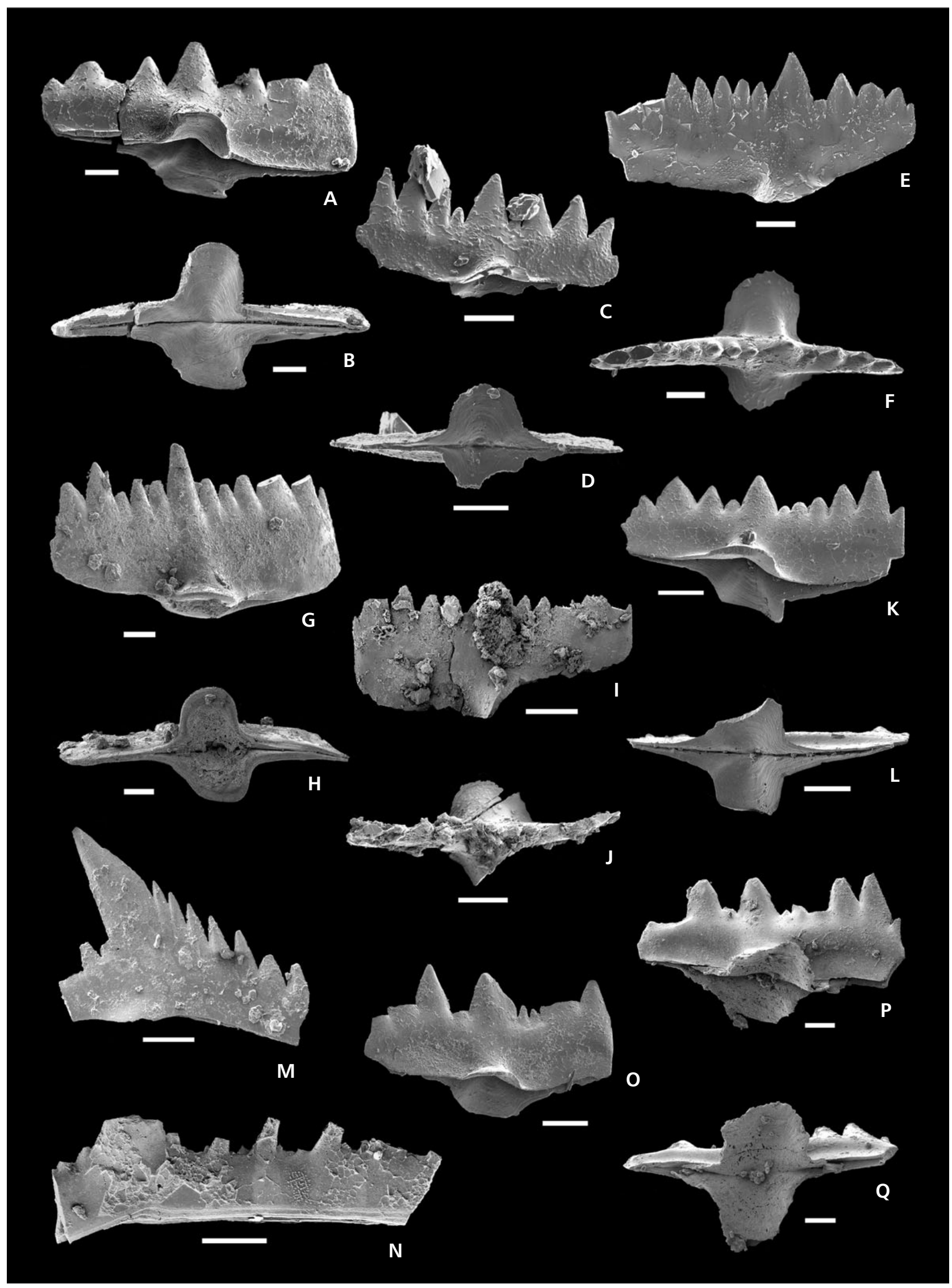


sulcata and kindlei zones in southern Alaska. Savage \& Gehrels (1984) obtained 29 Pa elements from horizons of kindlei Zone age, also from southern Alaska. Specimens of Oz. eberleini from the Booth Limestone have come from horizons of kindlei and pireneae age thus extending its known range.

\section{Ozarkodina excavata excavata (Branson \& Mehl, 1933)} Figures 20, 30W, X, 32L-Q

1933 Prioniodus excavatus n. sp.; Branson \& Mehl, p. 45, pl. 3, figs 7, 8 .

1933 Trichognathus excavata n. sp.; Branson \& Mehl, p. 51 , pl. 3 , fig. 35 .

1933 Ozarkodina simplex n. sp.; Branson \& Mehl, p. 52, pl. 3, figs 46, 47.

1994 Ozarkodina excavata (Branson and Mehl). Valenzuela-Ríos, pp. 69-70, pl. 4, fig. 4.

1995 Ozarkodina excavata excavata (Branson \& Mehl). Simpson \& Talent, pp. 147-152, pl. 8, figs 16-25, pl. 9, figs 1-24 (includes extensive synonymy).

1995 Ozarkodina excavata excavata (Branson \& Mehl). Colquhoun, pl. 1, fig. 16.

1995 Ozarkodina excavata excavata (Branson \& Mehl). Carey \& Bolger, pp. 79-81, fig. 3G, H.

1995 Ozarkodina excavata excavata (Branson \& Mehl). Dongal, fig. 4G-J.

1995 Ozarkodina excavata (Branson \& Mehl). - Miller, pl. 1, fig. 8 .

1995 Ozarkodina excavata excavata (Branson \& Mehl). Sloan et al., pl. 12, figs 15, 18.

1995 Ozarkodina excavata excavata (Branson \& Mehl). Furey-Greig, pl. 1, figs 12-14.

1998 Ozarkodina excavata excavata (Branson \& Mehl). Percival, fig. 4.2.

1998 Ozarkodina excavata excavata (Branson \& Mehl). Ferretti et al., pl. 2.2.1, fig. 1.

1998 Ozarkodina excavata excavata (Branson \& Mehl). Serpagli et al., pl. 1.2.1, figs 4, 5.

1998b Ozarkodina excavata excavata (Branson \& Mehl). Corradini et al., pl. 1.3.1, fig. 1.

1999 Ozarkodina excavata excavata (Branson \& Mehl). Talent \& Mawson, pl. 4, figs 1, 3, 4, pl. 5, figs 1-4, pl. 6, figs 19-22, pl. 7, fig. 14, pl. 9, figs 8, 9, pl. 11, figs $12-14$, pl. 12, figs $1-4$.
1999 Ozarkodina excavata excavata (Branson \& Mehl). Cockle, p. 120, pl. 3, figs 1-14.

1999 Ozarkodina excavata excavata (Branson \& Mehl). Talent et al., pl. 2, fig. 1.

1999 Ozarkodina excavata (Branson \& Mehl). - Viira, pl. 1, figs 1-4.

2000 Ozarkodina excavata excavata (Branson \& Mehl). Simpson, pp. 153-154, figs 5.12-5.26, 6.1-6.15.

2001 Ozarkodina excavata excavata (Branson \& Mehl). Slavík, pl. 2, figs 11, 15, 19.

2002 Ozarkodina excavata excavata (Branson \& Mehl). Talent et al., pl. 2, figs R, S, pl. 3, fig. S, pl. 4, fig. K.

2003 Ozarkodina excavata excavata (Branson \& Mehl). Mawson et al., pl. 3, figs 1-19, pl. 4, figs 1-15.

2003 Ozarkodina excavata excavata (Branson \& Mehl). Farrell, pp. 135-136, pl. 6, figs 10-21.

2004 Ozarkodina excavata excavata (Branson \& Mehl). Slavík \& Hladil, pl. 1, figs 14, 15, 17-19.

2004a Ozarkodina excavata excavata (Branson \& Mehl). Slavík, pl. 1, figs 10, 11.

2004b Ozarkodina excavata excavata (Branson \& Mehl). Slavík, fig. 11.25.

2004 Ozarkodina excavata (Branson \& Mehl). - Farrell, p. 970, pl. 9, figs 1-16.

2004 Wurmiella excavata (Branson \& Mehl). - Murphy et al., fig. 2.29-2.36.

2005 Ozarkodina excavata excavata (Branson \& Mehl). Talent et al., p. 282, figs 6D, 8C, D, F.

2005 Ozarkodina excavata excavata (Branson \& Mehl). Weddige et al., pl. 1, fig. 2.

2005 Ozarkodina excavata excavata (Branson \& Mehl). Trotter \& Talent, pl. 18, figs 2, 7-9.

2006 Ozarkodina excavata excavata (Branson \& Mehl). Valentine et al., p. 299, fig. 11i-m.

2007 Ozarkodina excavata excavata (Branson \& Mehl). Suttner, pp. 33-36, pl. 1, fig. 3, pl. 12, figs 1, 7, pl. 13 , figs $3,5,8,9$, pl. 14 , figs $2-11$, pl. 16 , figs 1-7, pl. 17, figs 1-3, 5 .

2008 Ozarkodina excavata excavata (Branson \& Mehl). Gaetani et al., pp. 280-281, pl. 1, fig. 4.

2009 Ozarkodina excavata excavata (Branson \& Mehl). Boncheva et al., text-fig. 4.4, 4.8, 4.10.

2009 Ozarkodina excavata excavata (Branson \& Mehl). Martín-Algarra et al., fig. 8.4-8.8.

2009 Ozarkodina excavata excavata (Branson \& Mehl). Suttner, pl. 1, fig. 15.

Figure 20. Ozarkodina excavata excavata (Branson \& Mehl, 1933). A-C - lateral oblique, upper and lateral views of Pa element MMMC 4539 from B 13. D - lateral view of Pa element MMMC 4540 from B $15 \mathrm{~W} . \bullet \mathrm{E}, \mathrm{F}-$ lateral and basal views of Pa element MMMC 4541 from B $15 \mathrm{~W}$. - G, $\mathrm{H}$ - lateral and lower views of Pa element MMMC 4542 from B 11D. $\bullet$ I lateral view of Pb element MMMC 4543 from MDAM 14. $\bullet$ J lateral view of Sa element MMMC 4544 from BE (Booth East). $\mathrm{K}$ - lateral view of Sc element MMMC 4545 from MDAM15. $\bullet \mathrm{L}-$ lateral view of Sc element MMMC 4546 from MDAM 10. $\bullet$ M - lateral view of Sc element MMMC 4547 from MDAM 17. $\bullet$ - lateral view of M element MMMC 4548 from GUND 3. Scale bar $=0.1 \mathrm{~mm}$. 


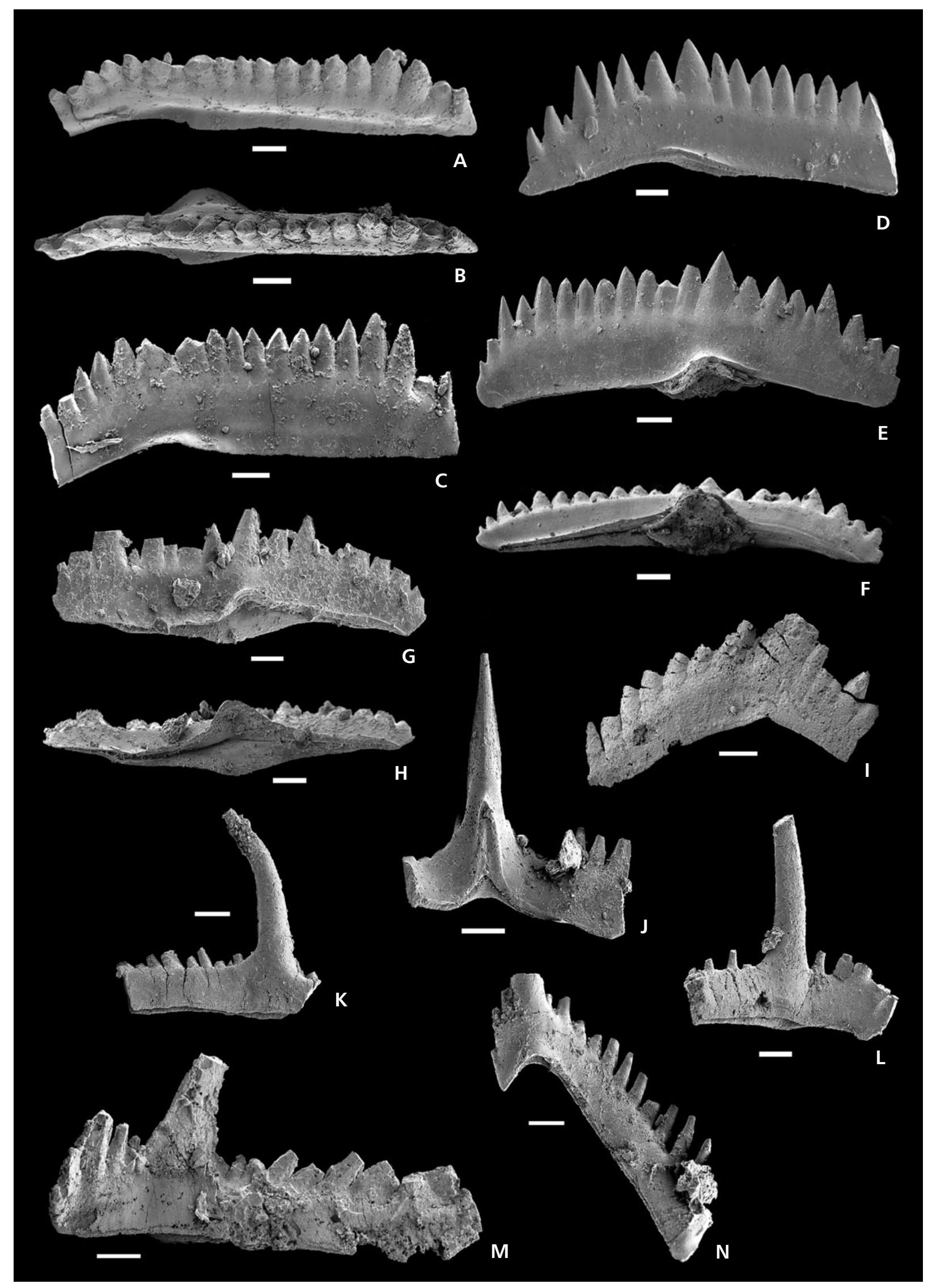


2010 Wurmiella excavata (Branson \& Mehl). - Corradini \& Corriga, pp. 248-250, pl. 2, figs 9-25.

2010 Wurmiella excavata (Branson \& Mehl). - Slavík et al., fig. 6A-T, V-CC.

2011 Wurmiella excavata (Branson \& Mehl). - Männik et al., fig. 4I-N.

2012 Wurmiella excavata (Branson \& Mehl). - Slavík \& Carls, figs 3B, D, G, H, 6A-ZZ.

2013 Wurmiella ex. gr. excavata (Branson \& Mehl). Männik et al., fig. 4a.

2013 Wurmiella excavata (Branson \& Mehl). - Männik et al., fig. 4b-d.

?2013 Gen. et sp. indet. B. - Rodríguez-Cañero et al., pl. 1, fig. 8 .

2014 Wurmiella excavata (Branson \& Mehl). - Corriga et al., fig. 6A.

Remarks. - Ozarkodina excavata excavata is recognised as a long-ranging species with its Pa element exhibiting a high degree of variation (e.g. Jeppsson 1975, Klapper \& Murphy 1975). Other elements are easily distinguished by their unique "excavated" basal cavities.

\section{Ozarkodina multistriola sp. nov.}

Figure 22

Holotype. - Pa element, specimen MMMC 4565 (Fig. 22A-C), from MDAM 11.

Type locality and horizon. - Sample MDAM 11 from Mountain Dam Limestone Member on "Marobee" station, approximately $90 \mathrm{~km} \mathrm{NW}$ of Condobolin, central New South Wales.

Etymology. - Striola, diminutive of stria (Latin) meaning furrow, channel, stripe, hollow, fluting, line, referring to the many fine striae on the surface of the denticles of all elements of this species.

Diagnosis. - A species of Ozarkodina with Pa elements having a long, lenticular basal cavity occupying two-thirds to three-quarters the length of the platform. Anterior denticles are backwardly deflected towards the posterior. Denticles of all elements are long and narrow; all are finely striated.

Description. - All elements are characterised by being finely striated with the striae being more prominent towards the top of the tapering denticles.

Pa element is characterised by a long, low blade with an anterior crest of approximately six or seven denticles being only slightly shorter than the anterior denticles and just a little higher that the posterior denticles. All but the denticles in the posteriormost quarter of the platform tend to curve towards the posterior. Denticles are narrow and long with traces of their depth highlighted by exterior striations evident for most of their length. The slightly asymmetrical basal cavity begins anterior of mid-length of the unit; it is very narrow and lenticular, tapering evenly to the posterior extremity.

$\mathrm{Pb}$ element is distinguished by having, in lateral view, high posterior denticles curved towards the wide main cusp, which also is curved towards the anterior. The anterior denticles are much higher than the posterior denticles and also have a tendency to curve towards the main denticle. Denticles are narrow and long with their individual shape defined by the striations down their length.

M, Sb and Sc elements all have a high main cusp with long, discrete, striate denticles with striae defining the shape. Sa element not so far identified.

Remarks. - The striate ornament on the denticles of all elements of $\mathrm{Oz}$. multistriola separate it from other ozarkodinans. Klapper \& Barrick (1983, pp. 1234-1237, figs $10 \mathrm{~K}, \mathrm{~N}, 11 \mathrm{~A}-\mathrm{W}$ ) described the late Eifelian Oz. raaschi, a species with $\mathrm{Pa}$ and $\mathrm{Pb}$ elements with striated denticles but having the $\mathrm{M}$ element and symmetry transition series smooth.

\section{Ozarkodina paucidentata (Murphy \& Matti, 1982) emended herein}

Figure $32 \mathrm{H}$, I

?1964 Spathognathodus steinhornensis remscheidensis Ziegler. - Walliser, pl. 20, fig. 26.

Figure 21. A-F - Ancyrodelloides omus Murphy \& Matti, 1983. - A, B - lateral and upper views of Pa element MMMC 4549 from B 11C. $\cdot \mathrm{C}, \mathrm{D}$ - lower and upper views of Pa element MMMC 4550 from B 11D. $\bullet$ E - upper view of Pa element MMMC 4551 from B 15E. $\bullet$ F - oblique upper view of Pa element MMMC 4552 from B 11C. • G-I - Ozarkodina eberleini Savage, 1977. • G - lateral view of Pa element MMMC 4553 from B 15 W. $\bullet \mathrm{H}$ - lateral view of Pa element MMMC 4554 from MDAM 7. • I - lateral view of Pa element MMMC 4554 from B $16 \mathrm{~L}$. $\bullet$ J-L - Pandorinellina exigua philipi (Klapper, 1969). $• \mathrm{~J}, \mathrm{~K}$ - lateral and lower views of Pa element MMMC 4555 from B 12. $\bullet$ L - lateral view of Pa element MMMC 4556 from B 11 (loose). $\bullet \mathrm{M}-\mathrm{P}-$ Pandorinellina exigua exigua (Philip, 1966). $\bullet \mathrm{M}, \mathrm{N}-$ lateral and lower views of Pa element MMMC 4557 from B $16 \mathrm{~L}$. $\bullet$ O, P - lateral and lower views of Pa element MMMC 4558 from B 16L. $\bullet \mathrm{Q}-\mathrm{Z}-$ Pandorinellina steinhornensis miae (Bultynck, 1971). $\bullet \mathrm{Q}-$ lateral view of Pa element MMMC 4559 from MDAM 35. $\bullet$ R, S - lateral and lower views of Pa element MMMC 4560 from MDAM 37. $\bullet$ T, U - lateral and upper views of Pa element MMMC 4561 from B 15W. $\bullet$ V, W - lateral and lower views of Pa element MMMC 4562 from MDAM $36 . \bullet X-l o w e r$ view of Pa element MMMC 4563 from GUND 3. $\bullet$ Y, Z - lateral and upper views of Pa element MMMC 4564 from GUND 3. Scale bar $=0.1 \mathrm{~mm}$. 


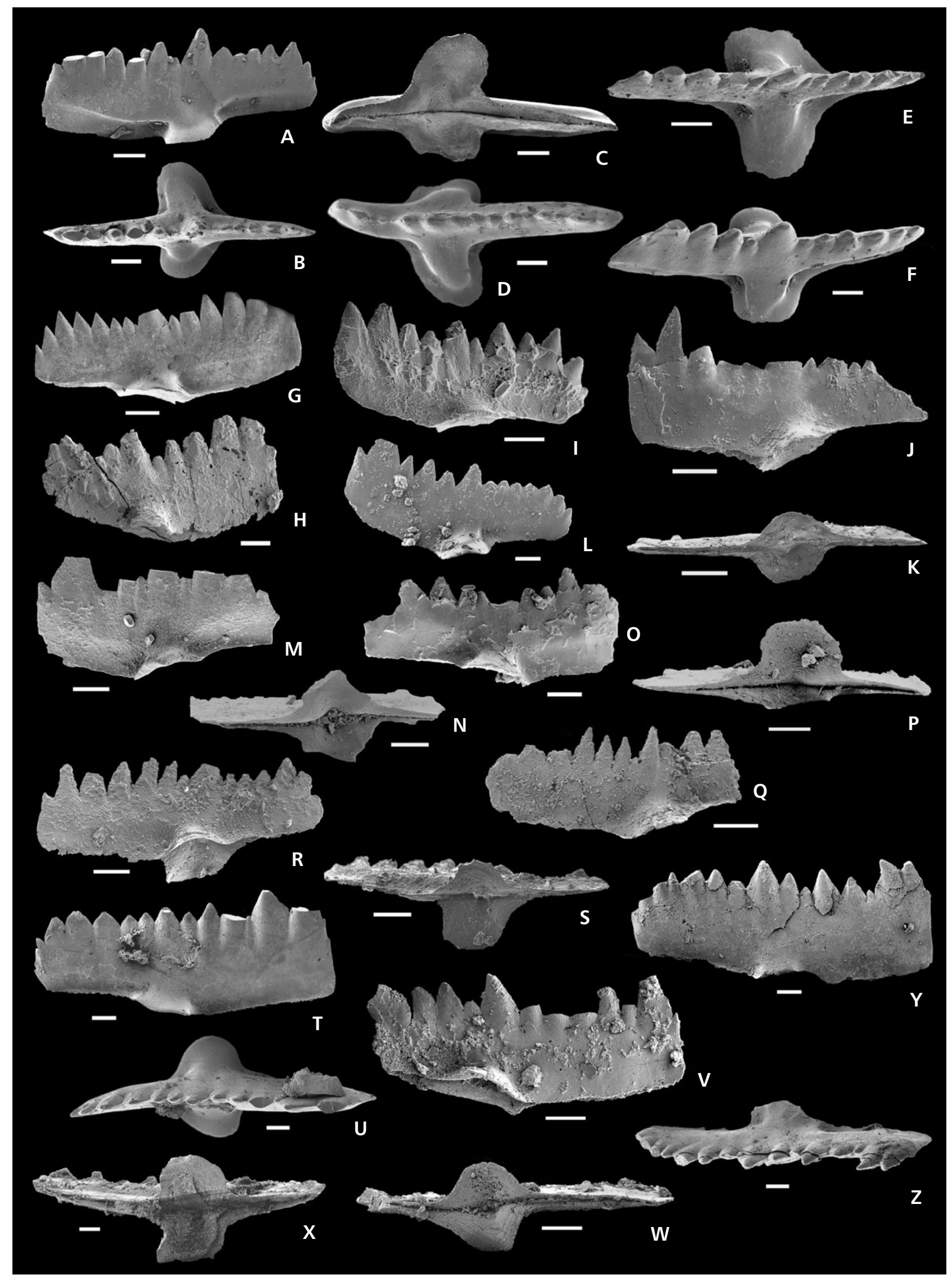


1975 Ozarkodina n. sp. E. - Klapper \& Murphy, pl. 7, figs $6,9,10$.

1982 Ozarkodina paucidentata n. sp.; Murphy \& Matti, pp. 9-10, pl. 1, figs 25-32, 39, 40.

2003 Ozarkodina sp. cf. O. paucidentata Murphy \& Matti - Mawson et al., p. 93, pl. 4, figs 19, 20.

2007 Ozarkodina aff. O. paucidentata Murphy \& Matti. Suttner, pp. 38-39, pl. 18, fig. 10.

2012 Zieglerodina paucidentata (Murphy \& Matti). Drygant \& Szaniawski, fig. 11R.

2012 Zieglerodina cf. paucidentata (Murphy \& Matti). Drygant \& Szaniawski, fig. 11S, T.

2013 "Ozarkodina" aff. paucidentata (Murphy \& Matti). - Mavrinskaya \& Slavík, fig. 6J-L.

Emended diagnosis. - A species of Ozarkodina characterised by a Pa element with a high conical cusp and no, or only rudimentary, development of denticles on a posterior process that is markedly lower adjacent to the cusp.

Remarks. - This species was originally diagnosed and named by Murphy \& Matti (1982, p. 9) based on material previously documented in open nomenclature by Klapper \& Murphy (1975). The diagnosis included the rudimentary nature of denticle development on the posterior process, but also stated that the number of denticles was three or four. The holotype, however, appears to have seven denticles on the posterior process (Murphy \& Matti 1982, pl. 1, figs 25-27, most obvious in upper view, fig. 26). The diagnosis also notes the almost circular nature of platform lobes in top view. While this is true of the holotype, other specimens show a distinct asymmetry (e.g. Murphy \& Matti 1982, pl. 1, fig. 31). The diagnosis is therefore emended to exclude these two characteristics and include the unifying characteristic of the relatively low posterior process.

A small number of $\mathrm{Pa}$ elements in this study fall within the emended diagnosis. Other specimens previously reported as having affinities with the species as originally diagnosed or compared with it, as captured in the above synonymy, now fall within the amended diagnosis.

\section{Ozarkodina selfi Lane \& Ormiston, 1979}

Remarks. - In their original description of Ozarkodina selfi, Lane \& Ormiston (1979) indicated that one of the diagnostic features of the species was the "heart- to ovalshaped" basal cavity. Materials from western New South Wales indicate that several subspecies can be identified on the basis of the shape of the basal cavity: Oz. selfi lenticula with a rounded, oval-shaped basal cavity; $O$. selfi lanceola with a lancet-shaped basal cavity; and $\mathrm{Oz}$. selfi cordata with a heart-shaped basal cavity similar to that of the specimen chosen as the holotype of the species by Lane \& Ormiston (1979, pl. 3, figs 18-20) but tapering more evenly towards the posterior extremity.

\section{Ozarkodina selfi lenticula subsp. nov.} Figures 23, 24A-L

1980 Ozarkodina cf. eurekaensis Klapper \& Murphy Pickett, p. 77, fig. 8A, B, D, J, L, M (only).

1999 Ozarkodina selfi Lane \& Ormiston. - Talent \& Mawson, pl. 12, fig. 5.

Holotype. - Pa element, specimen MMMC 4577 (Fig. 23A-C), from MDAM 18.

Type locality and horizon. - Sample MDAM 18 from the section through the Mountain Dam Limestone on "Marobee" station, approximately $90 \mathrm{~km} \mathrm{NW}$ of Condobolin, central New South Wales.

Etymology. - Lenticula (Latin), a little lens, in reference to the broadly lenticular shape of the basal cavity.

Diagnosis. - A subspecies of Ozarkodina selfi with $\mathrm{Pa}$ elements having a broadly lenticular basal cavity with rounded posterior extremities. Some denticles in the mid-third of the unit may be dimpled or show signs of coalescence of one or more dimpled denticles.

Description. - The Pa element is characterised by having a long, low blade with an anterior crest of approximately five or six laterally compressed denticles. In lateral view, the posterior margin tapers at an angle of $50^{\circ}$ to $65^{\circ}$ with two to four posterior denticles decreasing in height toward the posterior extremity. The mid and posterior section of denticles arch over a downwardly curved, unornamented

Figure 22. Ozarkodina multistriola sp. nov. A-C - upper, lateral and enlarged lateral views of Pa element, holotype MMMC 4565 from MDAM 11. - D, E - upper and lateral views of Pa element MMMC 4566 from MDAM 10. $\mathrm{F}$ - lateral view of Pa element MMMC 4567 from MDAM 4 . $\bullet$, H - lateral and enlarged lateral views of Pb element MMMC 4568 from MDAM 10. $\bullet$ - lateral view of Pb element MMMC 4569 from MDAM 35 . • J, K - lateral and enlarged lateral views of Sb element MMMC 4570 from BE. $\bullet$ L - lateral view of Sb element MMMC 4571 from MDAM 10. $\bullet$ M - lateral view of a portion of Sb element MMMC 4572 from MDAM 37. $\bullet \mathrm{N}$ - lateral view of Sc element MMMC 4573 from MDAM 17. $\bullet$ O - lateral view of portion of Sc element MMMC 4574 from MDAM 11. $\bullet$ - lateral view of M element MMMC 4575 from MDAM 4. $\bullet$ - lateral view of M element MMMC 4576 from MDAM 35. Scale bar $=0.1 \mathrm{~mm}$ except in $\mathrm{C}, \mathrm{K}$. 


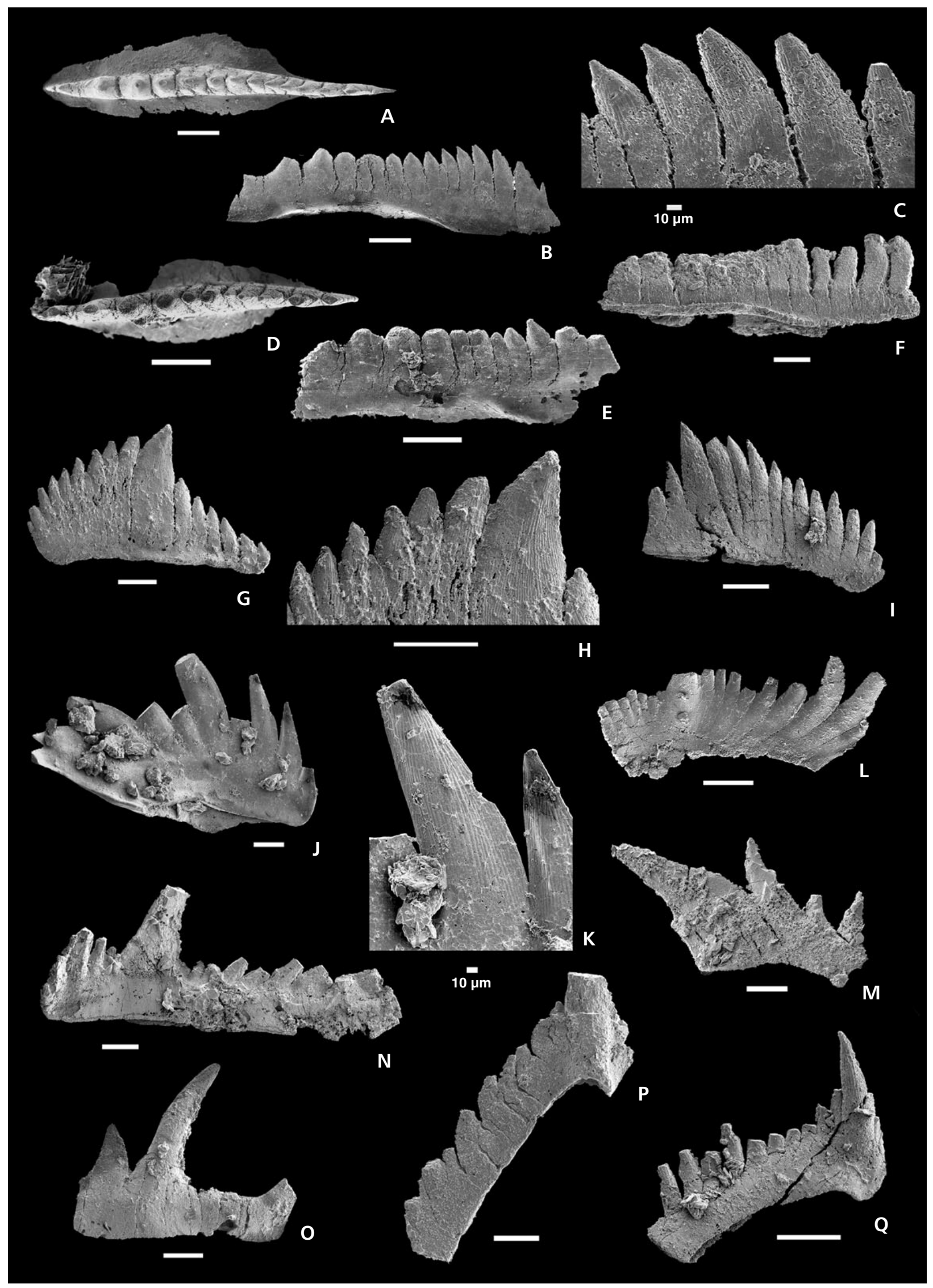


platform. Most denticles are fused almost to their tips but may retain discrete tips that are dimpled at times. The slightly asymmetrical basal cavity beginning anterior of mid-length is broadly lenticular with the posterior margin remaining rounded rather than pinched in where it reaches the posterior extremity.

Based on the nature of the mid-crest denticles, a range of morphologies of Ozarkodina selfi lenticula can be recognised. Mid-crest denticles may be either arched or somewhat flattened with most of the individual denticles pointed and complete. Other individual denticles tend to be dimpled. This morphology ranges to Pa elements in which denticles in the mid-crest area are flattened in lateral view by formation of dimples at their tops, and there are signs of coalescence between denticles. There was no observable stratigraphic trend within this range of morphologies in the collection studied.

Remarks. - Specimens of Oz. pandora zeta morph that exhibit mid-blade arching and fusion of mid-blade denticles were described and illustrated by Murphy et al. (1981, p. 765, pl. 2, fig. 20), but the specimens from Mountain Dam Limestone differ in having a much narrower basal cavity.

Specimens from the White Tank Limestone and Baledmund Formation illustrated by Picket (1980) are included in the synonmy because of the lenticular shape of the basal cavity.

\section{Ozarkodina selfi lanceola subsp. nov.}

Figures 25, 26A-O, 32J

1979 Eognathodus sulcatus juliae subsp. nov. - Lane \& Ormiston, pp. 52-53, figs 22, 23 (only).

1980 Ozarkodina cf. eurekaensis Klapper \& Murphy Pickett, p. 77, fig. 8E, F, G, H, K (only).

Holotype. - Pa element, specimen MMMC 4591 (Fig. 25A-D), from MDAM 17.

Type locality and horizon. - Sample MDAM 17 from the Mountain Dam Limestone on "Marobee" station, approximately $90 \mathrm{~km} \mathrm{NW}$ of Condobolin, central New South Wales.

Etymology. - Lanceola (Latin), a little spear; in reference to the narrow, spear-shaped basal cavity.

Diagnosis. - A subspecies of Ozarkodina selfi with Pa elements having a narrow, spear-shaped basal cavity and, in lateral view, a posterior margin sloping at an angle from $60^{\circ}$ to $90^{\circ}$

Description. - Viewed laterally, the Pa element has a relati- vely low, flat profile with the anterior denticles being slightly higher than the rest. The anterior denticles decrease in size and elevation towards the centre of the unit and appear to be laterally compressed to a greater degree than the posterior denticles. In upper view the unit is straight or slightly curved. The basal cavity tends to be narrow, lancet-shaped, occupying more than half of the unit and, approaching the posterior extremity of the unit, it is somewhat "pinched in".

Based on the nature of the central denticles a range of morphologies of Ozarkodina selfi lanceola can be recognised. Mid-crest may be either arched or somewhat flattened with most of the individual denticles cylindrical, round at the top and commonly dimpled, resembling cow teats in shape. This morphology ranges to $\mathrm{Pa}$ elements in which an incipient sulcus has formed by coalescence of dimpled denticles in the mid-third of the unit resulting in flattening of the crest of the blade in lateral view. The basal cavity is narrow and lancet-shaped with posterior extremities that are "pinched in" as they approach the posterior margin.

Remarks. - Specimens from Mountain Dam Limestone, the Booth Limestone and the "Lerida Limestone Member" are similar in some respects to $O z$. pandora pi morph illustrated by Murphy \& Matti (1982, pl. 1, figs 10-24). However, many of the specimens from the Mountain Dam Limestone show dimpled denticles in the central part of the unit and, in lateral view, the unit is somewhat flattened mid-crest, whereas none of the specimens illustrated from central Nevada shows these attributes.

A single specimen illustrated by Lane \& Ormiston (1979) is included in the synonymy as it has a single row of dentices that are partially fused and dimpled in the central area forming an incipient sulcus, and the basal cavity as shown in upper view is narrow and lanceolate. Other specimens illustrated by Lane \& Ormiston (1979) as Eognathodus sulcatus juliae are more sulcate and/or have a broader basal cavity.

Some of the specimens illustrated by Pickett (1980) are included in the synonymy on the basis of denticle and basal cavity morphology.

\section{Ozarkodina selfi cordata subsp. nov.}

Figure 26P-T

Holotype. - Pa element, specimen MMMC 4604 (Fig. 26P-R), from MDAM 23.

Type locality and horizon. - Sample MDAM 23 from the Mountain Dam Limestone Member on "Marobee" station, approximately $90 \mathrm{~km} \mathrm{NW}$ of Condobolin, central New South Wales. 


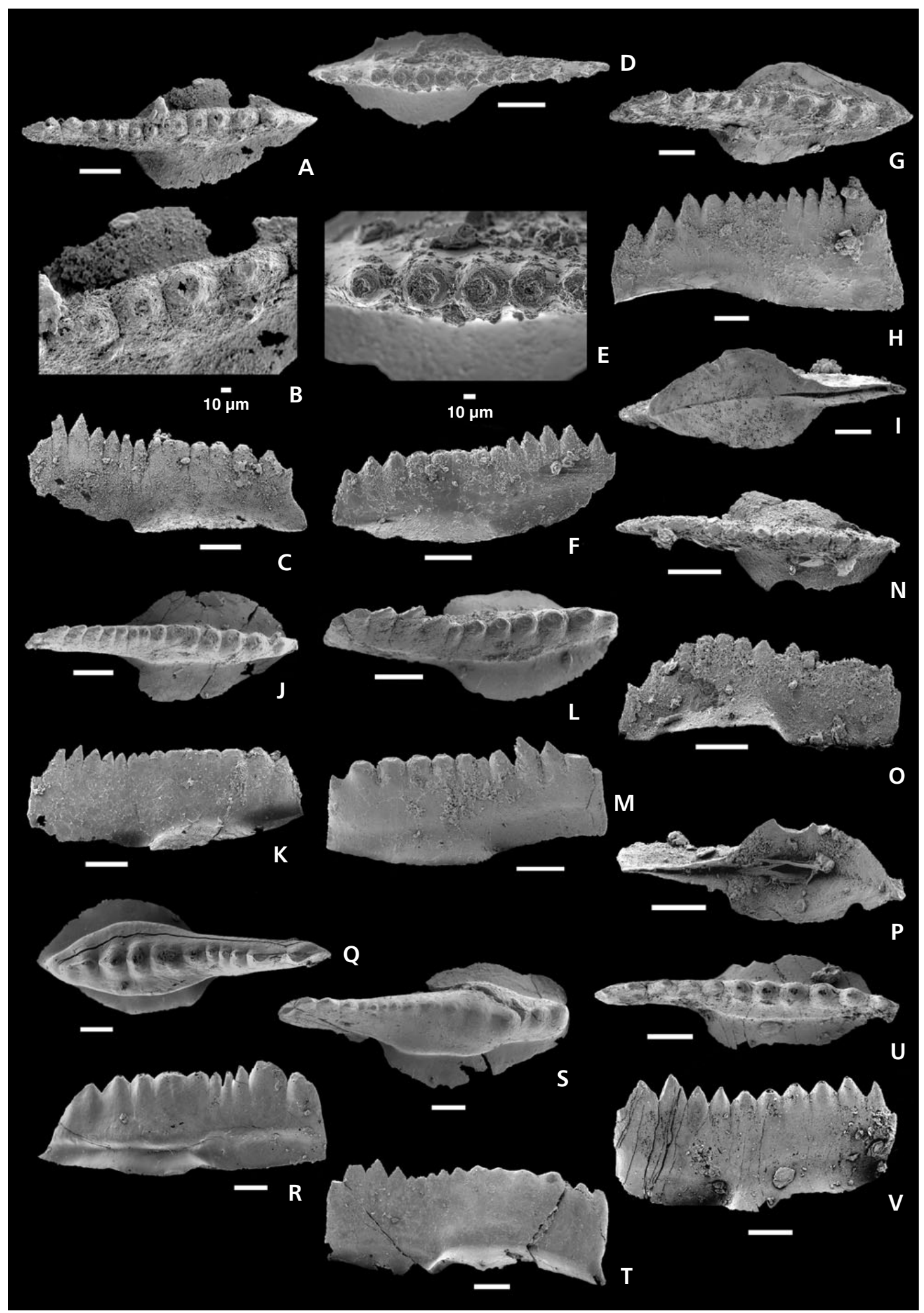

Figure 23. Ozarkodina selfi lenticula subsp. nov. $•$ A-C - upper, enlarged upper and lateral views of Pa element, holotype MMMC 4577 from MDAM 18. •D-F - upper, enlarged upper and lateral views of Pa element MMMC 4578 from B 12. • G-I - upper, lateral and lower views of Pa element MMMC 4579 from MDAM 13. $\bullet$ J, K - upper and lateral views of Pa element MMMC 4580 from MDAM 15. $\bullet$ L, M - upper and lateral views of Pa element MMMC 4581 from GUND 5. $\bullet$ N-P - upper, lateral and lower views of Pa element MMMC 4582 from MDAM 31. $\bullet$, R - upper and lateral views of gerontic Pa element MMMC 4583 from B 15W. $\bullet \mathrm{S}, \mathrm{T}$ - upper and lateral views of gerontic Pa element MMMC 4584 from MDAM 15. $\bullet, \mathrm{V}-$ upper and lateral views of Pa element MMMC 4585 from GUND 2. Scale bar $=0.1 \mathrm{~mm}$ except in B, E. 


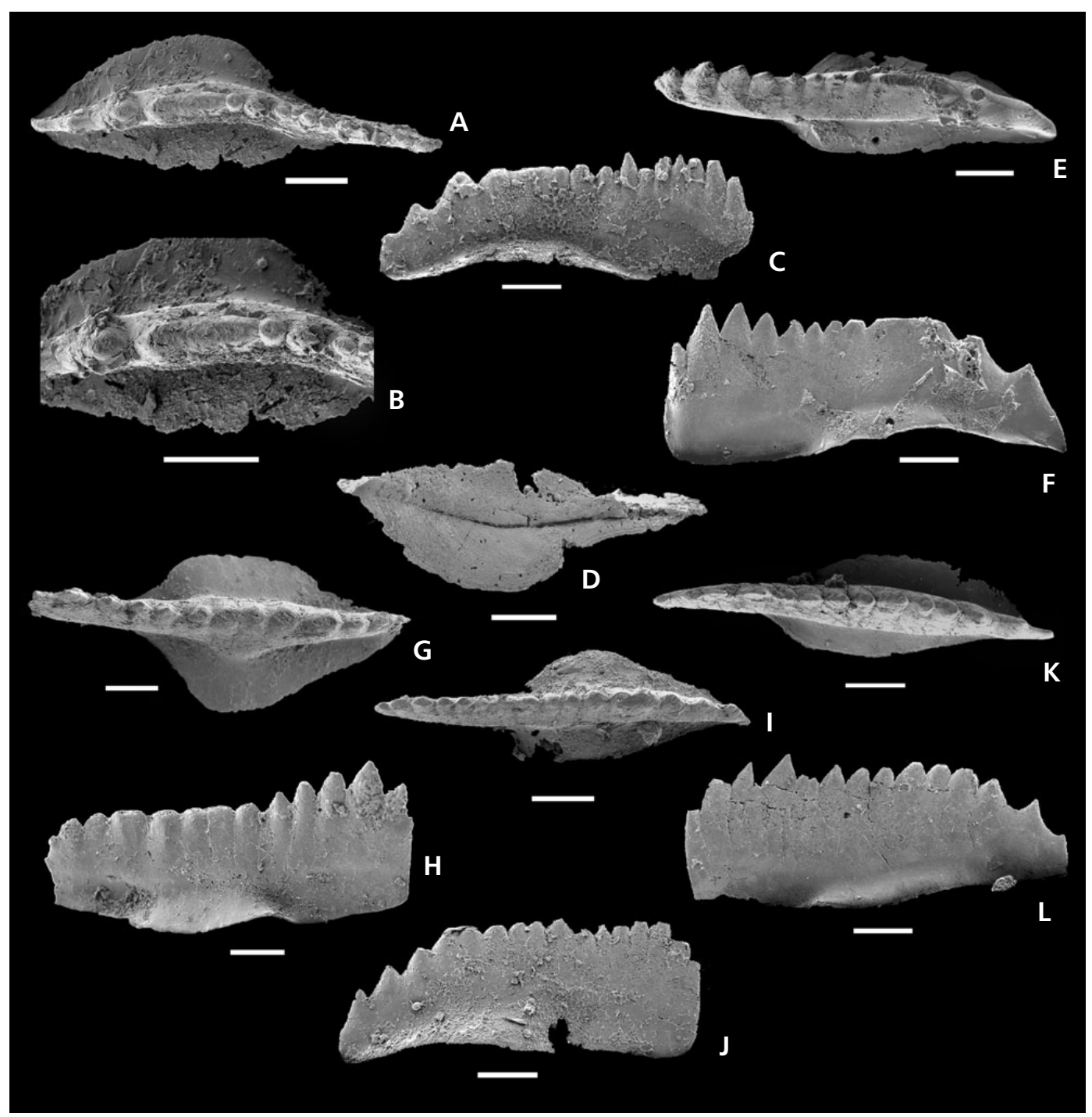

Figure 24. Ozarkodina selfi lenticula subsp. nov. • A-D - upper, enlarged upper, lateral and lower views of Pa element MMMC 4586 from MDAM South. $\bullet$ E, F - upper and lateral views of Pa element MMMC 4587 from MDAM 17. $\bullet \mathrm{G}, \mathrm{H}-$ upper and lateral views of Pa element MMMC 4588 from GUND 5. $\bullet \mathrm{I}, \mathrm{J}$ - upper and lateral views of Pa element MMMC 4589 from MDAM 17. $\bullet \mathrm{K}, \mathrm{L}-$ upper and lateral views of Pa element MMMC 4590 from MDAM 15. Scale bar $=0.1 \mathrm{~mm}$.

Etymology. - Cordata (Latin), heart-shaped, in reference to the heart-shaped basal cavity.

Diagnosis. - A subspecies of Ozarkodina selfi with the $\mathrm{Pa}$ element having a heart-shaped basal cavity that tapers to the posterior extremity and, in lateral view, a posterior margin sloping abruptly at an angle from $80^{\circ}$ to $90^{\circ}$.
Description. - The single row of denticles appears, in lateral view, to be a little flattened or slightly arching in the central half of the unit. Central denticles are fused almost to their tips but most retain discrete tips. Posterior denticles are taller and more discrete. In lateral view, the posterior margin of the unit is almost perpendicular to the base. The basal cavity is heart-shaped, slightly asymmetrical, tapers

Figure 25. Ozarkodina selfi lanceola subsp. nov. • A-D - upper, lateral and two enlarged upper views of Pa element, holotype MMMC 4591 from MDAM 17. • E, F - upper and lateral views of Pa element MMMC 4592 from MDAM 23. • G-I - lateral, upper and lower views of Pa element MMMC 4693 from MDAM 22. • J, K upper and lateral views of Pa element MMMC 4594 from B 15W. $\bullet$ L, M - upper and lateral views of Pa element MMMC 4595 from MDAM 17. $\bullet \mathrm{N}-\mathrm{P}$ - upper, lateral and lower views of gerontic Pa element MMMC 4596 from MDAM $12 . \bullet \mathrm{Q}, \mathrm{R}-$ upper and lower views of Pa element MMMC 4597 from MDAM 15. Scale bar = $0.1 \mathrm{~mm}$ except in C, D. 


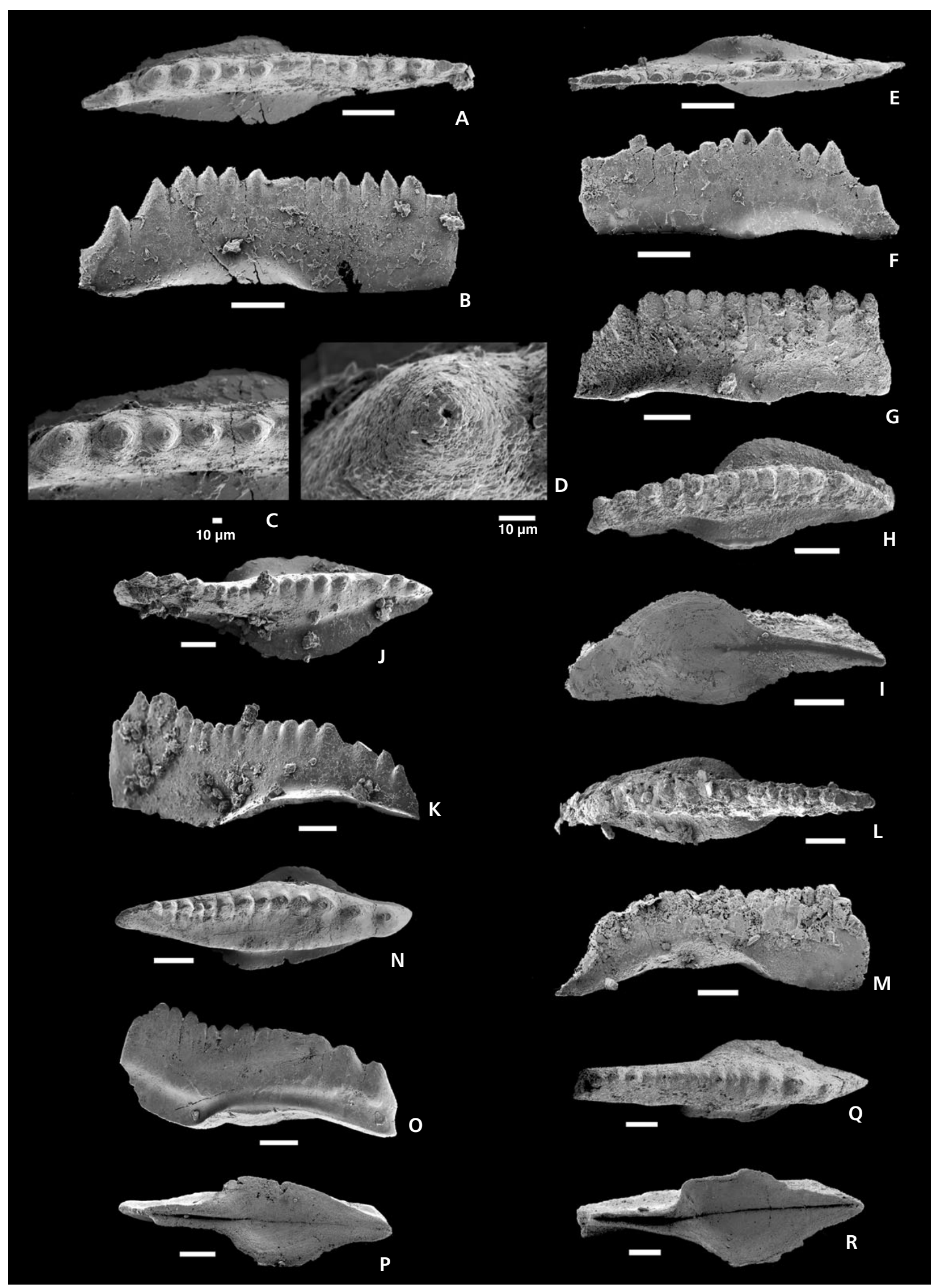


evenly to the posterior margin, and occupies a little more than the posterior half of the unit.

Remarks. - The basal cavity of the holotype of Oz. selfi (sensu stricto) (Lane \& Ormiston 1979, pl. 3, figs 18-20) differs from that of the new subspecies in that the former shows the heart-shaped basal cavity tapering to a point about one-quarter the length of the unit from the posterior margin and continuing as a groove to the posterior extremity. The heart-shaped basal cavity of $O z$. selfi cordata tapers more evenly.

Because of the heart-shaped basal cavity of $O z$. selfi cordata, it is suggested that it gave rise to Eognathodus sulcatus juliae with its basal cavity tapering more evenly than that of $\mathrm{Oz}$. selfi (sensu stricto).

\section{Ozarkodina remscheidensis remscheidensis (Ziegler, 1960)}

Figures 27, 32K

1960 Spathognathodus remscheidensis n. sp.; Ziegler, pp. 194-196, pl. 13, figs 1, 2, 4, 5, 7, 8, 10, 14.

2001 Ozarkodina remscheidensis remscheidensis (Ziegler). - Slavík, pl. 2, fig. 9.

2003 Ozarkodina remscheidensis remscheidensis (Ziegler). - Mawson et al., pp. 90-92, pl. 2, figs 1-19, pl. 4, figs 17,18 (with synonymy to 2003).

2003 Ozarkodina remscheidensis remscheidensis (Ziegler). - Farrell, pp. 90-92, pl. 2, figs 1-19, pl. 4, figs $16,17$.

2004 Zieglerodina remscheidensis (Ziegler). - Murphy et al., p. 13, fig. 3.1-3.8.

2005 Ozarkodina remscheidensis remscheidensis (Ziegler). - Weddige et al., pl. 1, fig. 1.

2005 Ozarkodina remscheidensis remscheidensis (Ziegler). - Trotter \& Talent, pl. 18, figs 1, 3-6, 8.

2007 Ozarkodina remscheidensis remscheidensis (Ziegler). - Suttner, pp. 39-42, pl. 12, figs 5, 6, 8, pl. 17, figs $6-13$, pl. 18, fig. 1 (with synonymy to 2007).

2007 Ozarkodina remscheidensis remscheidensis (Ziegler). - Benfrika et al., fig. 8A.

2008 Ozarkodina remscheidensis remscheidensis (Ziegler). - Gaetani et al., p. 281, pl. 1, fig. 1.

2008 Ozarkodina remscheidensis remscheidensis (Ziegler). - Kim et al., pl. 16, figs 6, 7.
2009 Ozarkodina remscheidensis remscheidensis (Ziegler). - Suttner, pp. 79-80, pl. 1, figs 9, 10.

2009 Ozarkodina remscheidensis remscheidensis (Ziegler). - Martín-Algarra et al., fig. 8.9.

2010 Zieglerodina remscheidensis (Ziegler). - Drygant, pp. 49-52, pl. 1, figs 1-8, 13 (only).

2012 Ozarkodina remscheidensis (Ziegler). - Baranov, pl. 1, figs 9-11.

2012 Zieglerodina remscheidensis (Ziegler). - Drygant \& Szaniawski, fig. 12A-G.

Remarks. - Following the introductory comments made by Simpson \& Talent (1995), Mawson et al. (2003) continued discussions on the chronologic significance and phylogenetic relationships of the highly variable Ozarkodina remscheidensis plexus. Based on the fact that Oz. r. remscheidensis (sensu stricto) can be identified by its irregular denticulation with a large cusp and a group of large denticles along the anterior of the blade, and with an enlarged denticle about mid-way above a heart-shaped (rather than an ear-shaped) basal cavity, we have synonymised several forms recently described as new species.

One form (Fig. 27U, V) differs from most of our other specimens in having denticles that are arranged in an irregular row and having basal cavity lobes that are decidedly different in width compared with $O z . r$. remcheidensis. It is included in $O z$. r. remschiedensis as an aberrant form.

\section{Ozarkodina scoliciformis sp. nov.} Figure 28A-I

1994 Ozarkodina sp.; Mawson \& Talent, fig. 13M.

Holotype. - Pa element, specimen MMMC 4621 (Fig. 28C, D), from MDAM 15.

Type locality and horizon. - Sample MDAM 15 from the Mountain Dam Limestone on "Marobee" station, approximately $90 \mathrm{~km} \mathrm{NW}$ of Condobolin, central New South Wales.

Etymology. - Scolex (Latin) and formis (Latin), worm-like, in reference to the appearance of the Pa element.

Diagnosis. - A species of Ozarkodina with the Pa element

Figure 26. A-O-Ozarkodina selfi lanceola subsp. nov. • A-C - upper, enlarged upper and lateral views of Pa element MMMC 4598 from MDAM 35. - D-F - upper, enlarged upper and lateral views of Pa element MMMC 4599 from MDAM 12. $\bullet$ G-I - upper, enlarged upper and lateral views of Pa element MMMC 4600 from MDAM 35. • J, K - upper and lateral view of Pa element MMMC 4601 from MDAM 17. $\bullet \mathrm{L}, \mathrm{M}-$ upper and lateral views of Pa element MMMC 4602 from MDAM 9. $\bullet \mathrm{N}, \mathrm{O}-$ upper and lateral views of Pa element MMMC 4603 from MDAM 25. $\bullet$ P-T - Ozarkodina selfi cordata subsp. nov. $\bullet \mathrm{P}-\mathrm{R}-$ upper, lateral and enlarged upper views of Pa element, holotype MMMC 4604 from MDAM 23. $\bullet$ S, T - upper and enlarged upper view of Pa element MMMC 4605 from GUND 2. Scale bar $=0.1 \mathrm{~mm}$ except in $\mathrm{E}, \mathrm{H}, \mathrm{R}, \mathrm{T}$. 


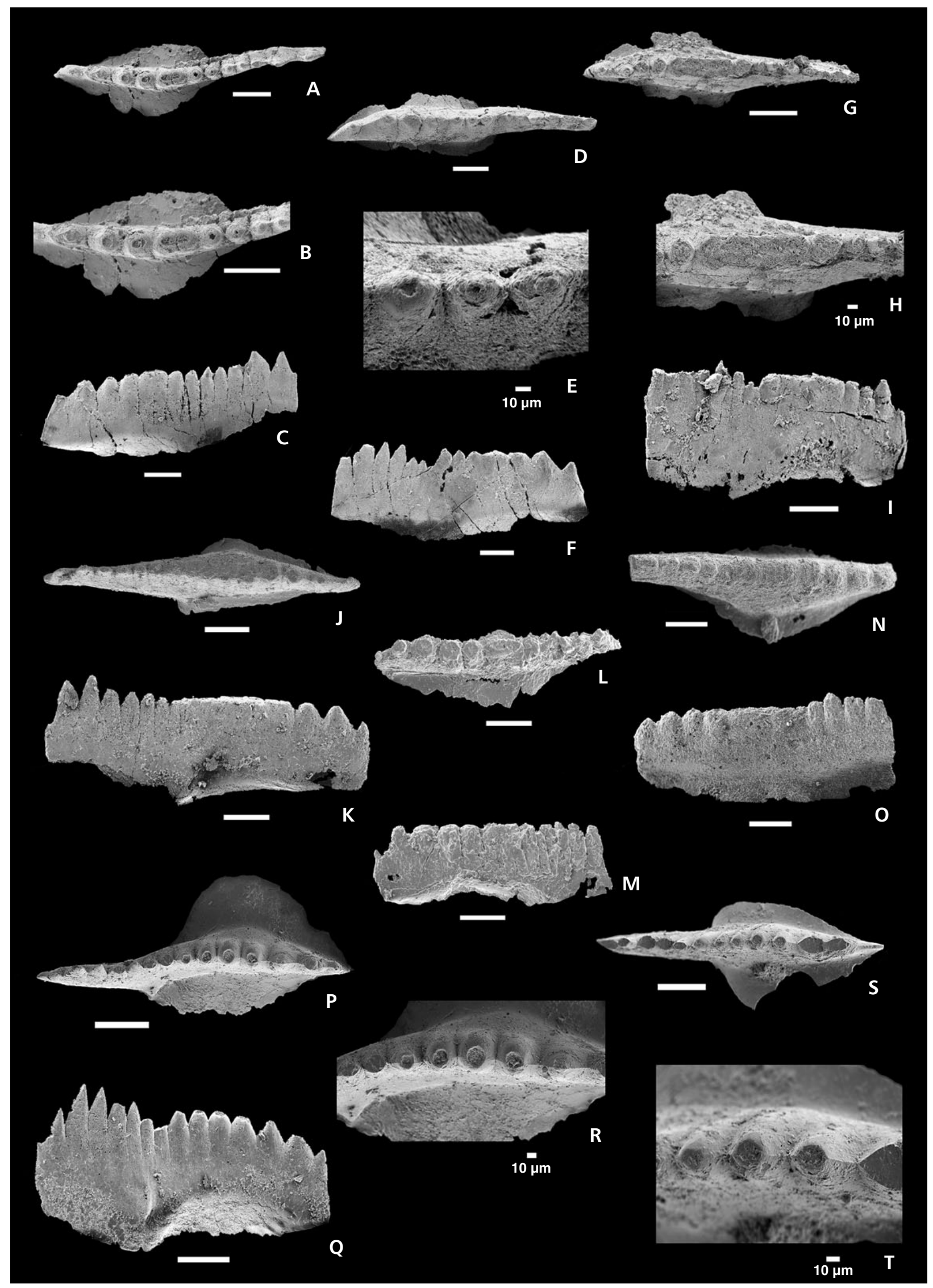


having a proportionally long, narrow and thickened blade giving the unit the appearance of a slug or worm.

Description. - In lateral view the thickened blade is long and extremely narrow with its base tending to bow downwards in the posterior half of the unit, giving it a worm-like or slug-like appearance. In lateral view, the denticles are short and closely packed with the denticles in the anterior third of the unit forming a slightly higher crest. Denticles in the posterior third of the unit are fused almost to their tips and decrease in height rapidly. The basal cavity is long and very narrow, occupying the posterior three-quarters of the unit.

Remarks. - Because of the extremely narrow basal cavity of this species, it is suggested that $O z$. scoliciformis may have been derived from the ozarkodinan Ozarkodina scotti Farrell (2003) from a Lochkovian horizon in the Garra Limestone at The Gap, New South Wales.

\section{Genus Pandorinellina Müller \& Müller, 1957}

Type species. - Pandorina insita Stauffer, 1940.

\section{Pandorinellina exigua exigua? (Philip, 1966)} Figure 21M-P

Remarks. - Pandorinellina exigua exigua has an age range from at least the dehiscens Zone through to the top of the serotinus Zone (Klapper \& Johnson 1980) whereas $P$. e. philipi has been reported from horizons dated as sulcatus Zone through to the perbonus/gronbergi/nothperbonus Zone. Therefore, if with further sampling the queried identification of the two specimens from B 16L horizon can be confirmed as unequivocally $P$. e. exigua, the highest horizon of the Booth Limestone cropping out in the Multagoona Anticline is dehiscens Zone in age.

\section{Pandorinellina exigua philipi (Klapper, 1969)}

Figures 21J-L, 31A-F

1969 Spathognathodus exiguus philipi n. ssp.; Klapper, pp. 16-18, pl. 4, figs 30-38.

1973 Pandorinellina exigua philipi (Klapper). - Ziegler, pp. 321-322, pl. 2, fig. 11.

1977 Pandorinellina exigua philipi (Klapper). - Savage et al., pl. 1, figs 1-12.

Figure 27. Ozarkodina remscheidensis remscheidensis (Ziegler, 1960). • A, B - lateral and upper views of Pa element MMMC 4606 from MDAM 36. - C, D - lateral and lower views of Pa element MMMC 4607 from MDAM 7. • E, F - lateral and lower views of Pa element MMMC 4608 from MDAM 36. $\bullet \mathrm{G}, \mathrm{H}$ - lateral and upper views of Pa element MMMC 4609 from MDAM 35. • I, J - lateral and upper views of Pa element MMMC 4610 from BLUFF 1. $\mathrm{K}, \mathrm{L}-$ lateral and lower views of Pa element MMMC 4611 from B 9. • M, N - lateral and upper views of Pa element MMMC 4612 from B $15 \mathrm{~W} \cdot \bullet \mathrm{O}-$ lateral view of $\mathrm{Pb}$ element MMMC 4613 from MDAM 35. $\cdot \mathrm{P}$ - lateral view of $\mathrm{Pb}$ element MMMC 4614 from MDAM 33 . $\bullet \mathrm{Q}-1$ lateral view of $\mathrm{Pb}$ element MMMC 4615 from MDAM 35. $\bullet \mathrm{R}$ - lateral view of Sb element MMMC 4616 from MDAM 23. $\bullet$ - lateral view of Sc element MMMC 4617 from B 15W. $\bullet$ T lateral view of M element MMMC 4618 from GUND 3. $\bullet$, V - upper and lateral views of Pa element MMMC 4619 from BLUFF 1. Scale bar $=0.1 \mathrm{~mm}$.

Figure 28. A-I - Ozarkodina scoliciformis sp. nov. • A, B - lateral and lower views of Pa element MMMC 4620 from MDAM 24. $\bullet$ C, D - lateral and lower views of Pa element, holotype MMMC 4621 from MDAM 15. E - lateral view of Pa element MMMC 4622 from MDAM $26 . \bullet F$, G - lateral and lower views of Pa element MMMC 4623 from MDAM 15. • H, I - lateral and lower views of Pa element MMMC 4624 from MDAM 29. - J-S - Heliagnathus parvilabiatus sp. nov. $\bullet \mathrm{J}, \mathrm{K}$ - lateral and oblique lower views of Pa element, holotype MMMC 4625 from MDAM $31 . \bullet$ L - lateral outer view of Pb element MMMC 4626 from BE. $\bullet \mathrm{M}$ - lateral inner view of Pb element MMMC 4627 from GUND 5. $\bullet$ N lateral view of Sa element MMMC 4628 from B 16G. • O - lateral view of M element MMMC 4629 from MDAM 34. $\bullet$ P - lateral view of broken Sc element MMMC 4630 from MDAM 37. $\bullet \mathrm{Q}-$ lateral view of Sb element MMMC 4631 from MDAM 14. $\bullet$ R, S - lateral and oblique lower views of Sb element MMMC 4632 from MDAM 31. Scale bar $=0.1 \mathrm{~mm}$.

Figure 29. A-I - Apparatus A. • A, B - lateral and lower views of Pb element MMMC 4633 from B 12 . $\bullet$ C, D - lateral and lower views of Pb element MMMC 4634 from MDAM 4. E , F - lateral and lower views of Pb element MMMC 4635 from BE. $\bullet$ G, H - lateral view and enlarged portion of posterior three denticles showing annealing of broken denticles of Pb element MMMC 4636 from B 16C. $\bullet$ I - oblique lateral view of Sa element MMMC 4637 from BE. • J-L, N-P - unassigned "ozarkodinan" elements. • J - lateral view of broken Sa element MMMC 4638 from MDAM $36 . \bullet \mathrm{K}-$ lateral view of ?Sb element MMMC 4639 from MDAM 33. $\bullet$ L - lateral view of Sb element MMMC 4640 from MDAM 36. • N - lateral view of Sa element MMMC 4641 MDAM 17. - O - lateral view of Sa element MMMC 4642 from MDAM 8. • P - lateral view of Pb element MMMC 4643 from B 16L. - M, Q-T - unassigned elements. • M - lateral view of Sb element MMMC 4644 from MDAM 5. $\bullet$ Q - lateral view of Sa element MMMC 4645 from MDAM 15. $\bullet$ R - lateral view of ?Pb element MMMC 4646 from MDAM 10. $\bullet$ S, T - lateral and lower views of icriodontid M2 element MMMC 4647 from BE. Scale bar $=0.1 \mathrm{~mm}$. 


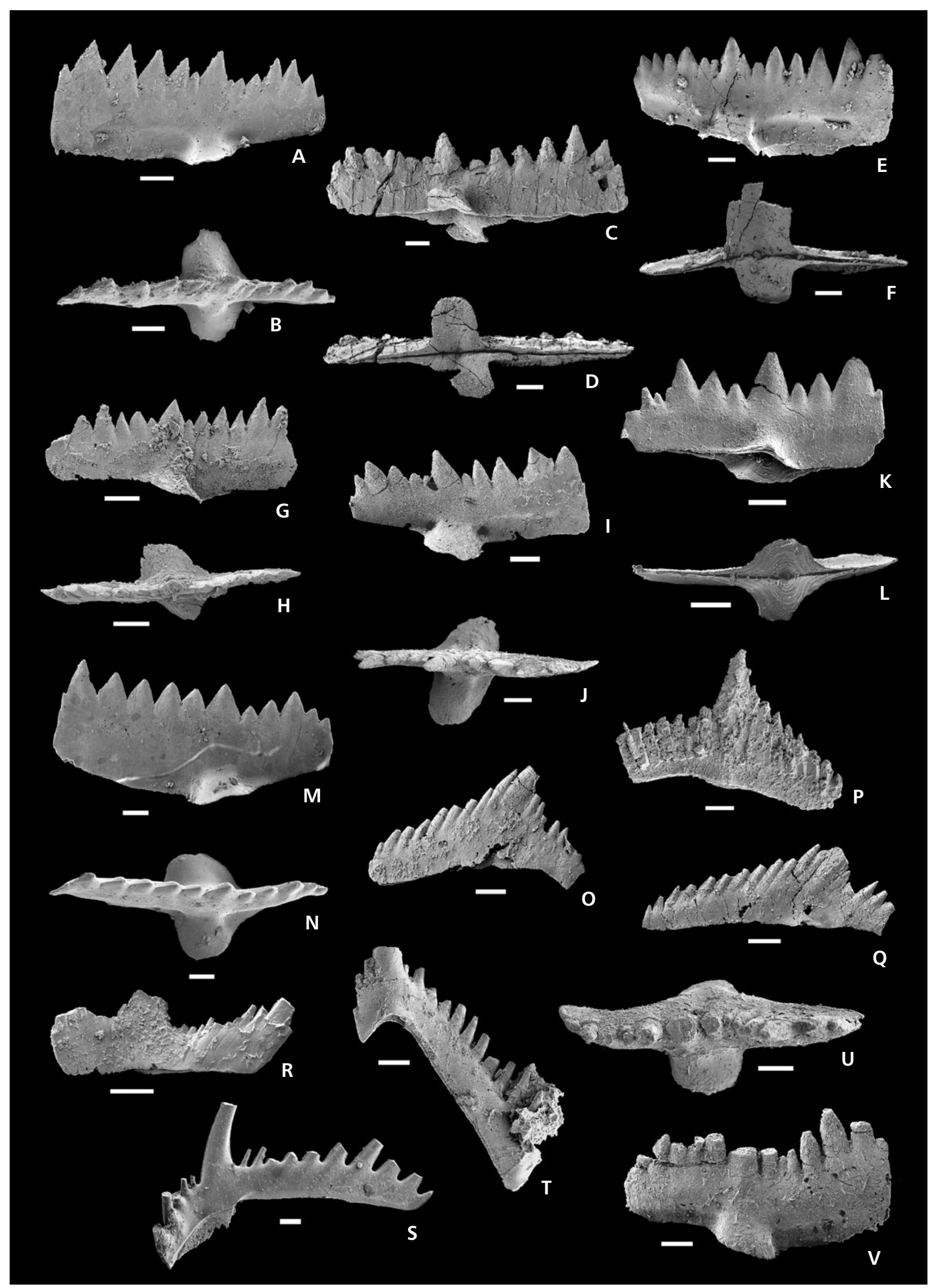




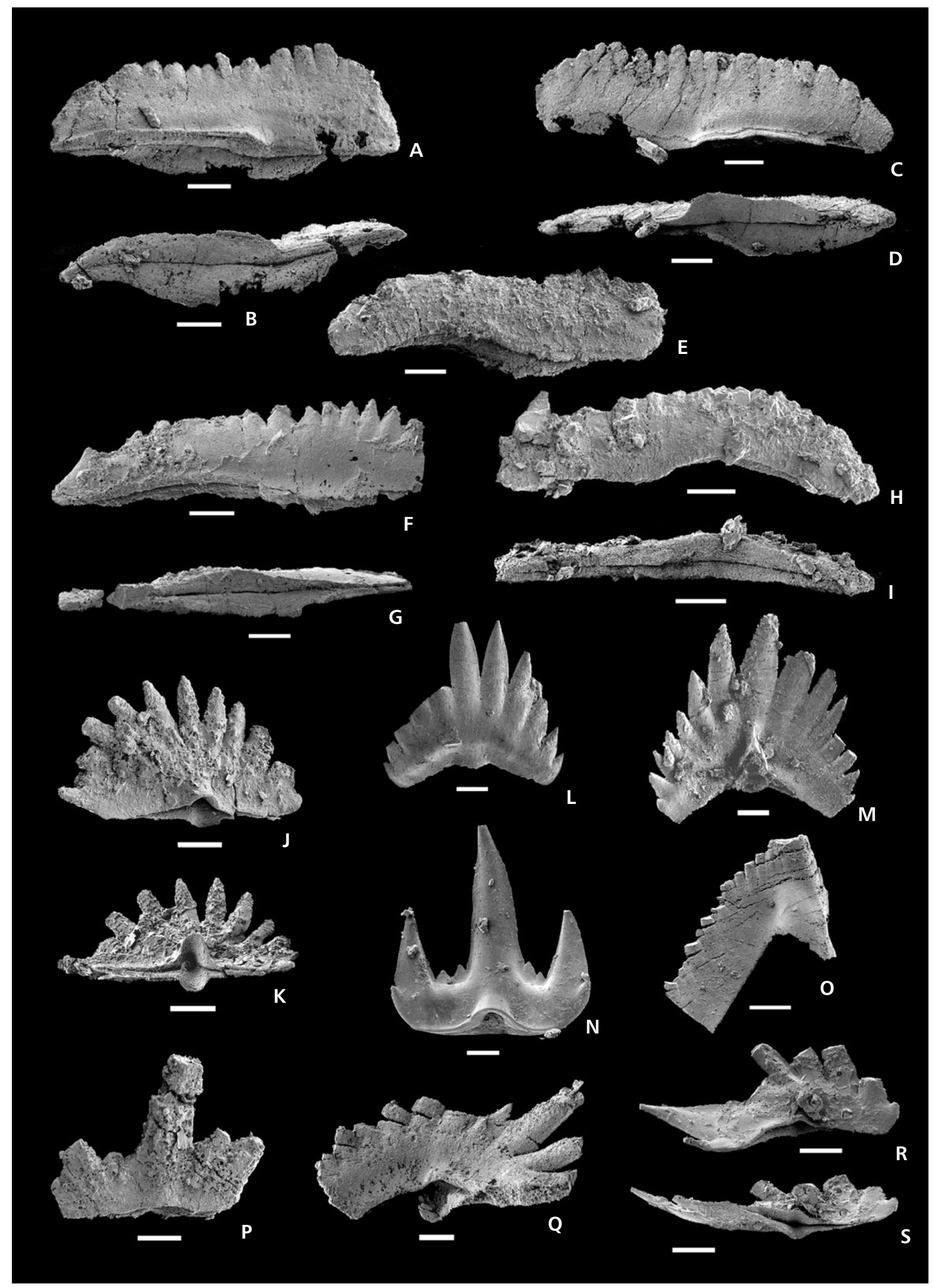




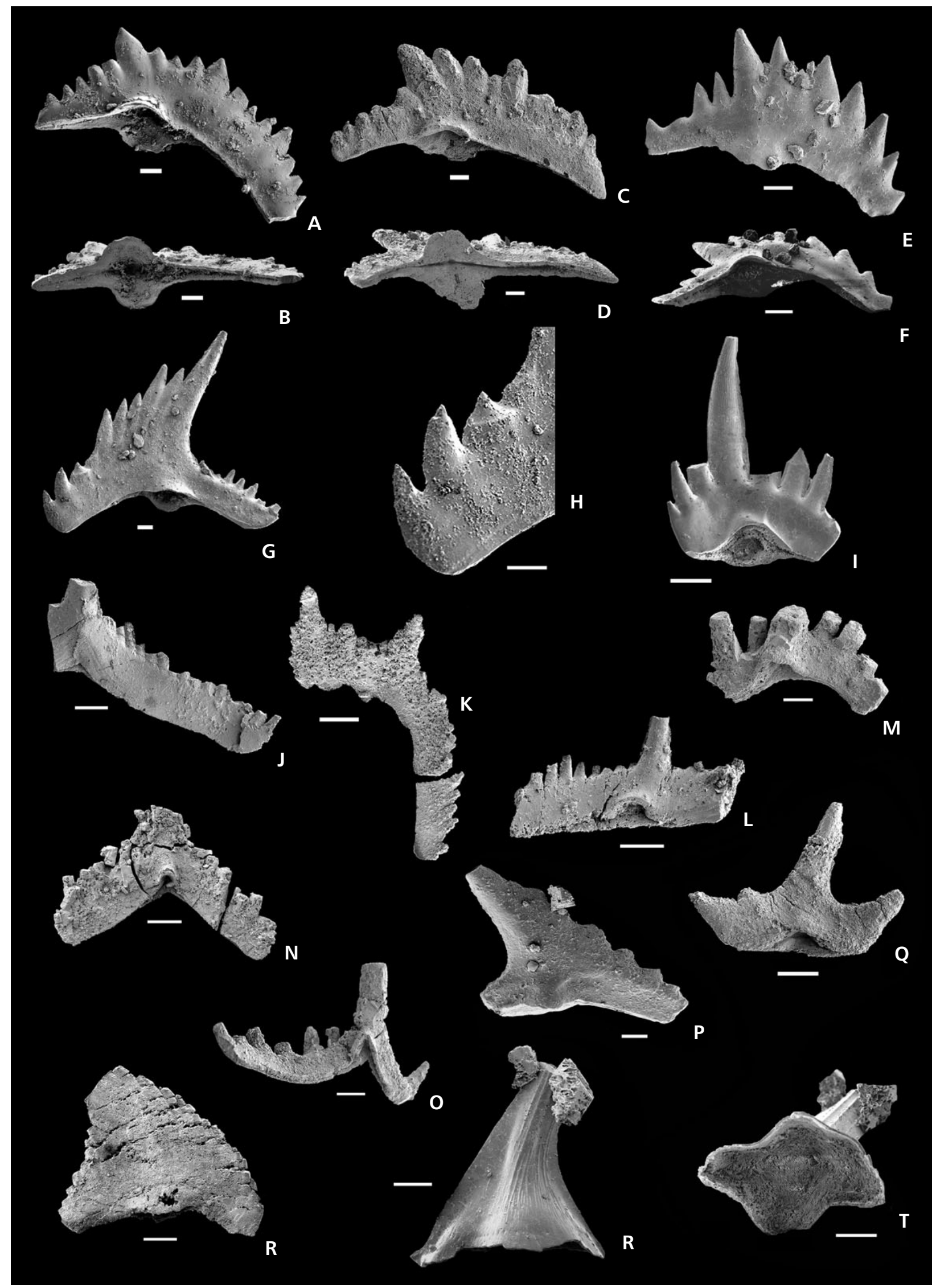


1977 Pandorinellina exigua philipi (Klapper). - Savage, p. 281, pl. 1, figs 33, 34 .

1979 Pandorinellina exigua philipi (Klapper). - Lane \& Ormiston, p. 59, pl. 6, figs 1-3.

1984 Pandorinellina exigua philipi (Klapper). - Savage \& Gehrels, p. 1424, pl. 2, figs 13-15.

1985 Pandorinellina exigua philipi (Klapper). - Savage et al., pl. 1, figs 16, 17.

1989 Pandorinellina exigua philipi (Klapper). - Wilson, pp. 141-142, pl. 10, figs 21-23.

1990 Pandorinellina exigua philipi (Klapper). - Uyeno, p. 96, pl. 6, figs 1-6, 41.

1990 Pandorinellina exigua philipi (Klapper). - Bischoff \& Argent, pl. 4, figs 19-28.

1991 Pandorinellina exigua philipi (Klapper). - Uyeno, pl. 1, fig. 20.

1992 Pandorinellina exigua philipi (Klapper). - Bardashev \& Ziegler, pl. 1, figs 40, 46.

1992 Pandorinellina exigua philipi (Klapper). - Mawson et al., figs 9K, L, 11R (non fig. $13 \mathrm{O}=$ Pandorinellina? sp.).

1994 Pandorinellina exigua philipi (Klapper). - Sobolev, pl. 13, figs 4, 5 .

1995 Pandorinellina exigua philipi (Klapper). - Colquhoun, pl. 2, figs 1, 3, 4.

1999 Pandorinellina exigua philipi (Klapper). - Talent \& Mawson, pl. 7, fig. 9, pl. 9, fig. 10, pl. 12, figs 6, 8, 9.

2003 Pandorinellina exigua philipi (Klapper). - Farrell, pp. 146-147, pl. 10, figs 9-19.

2003 Pandorinellina exigua philipi (Klapper). - Sloan, pl. 2, figs 13-15.

2003 Pandorinellina exigua philipi (Klapper). - Mawson \& Talent, p. 347, pl. 1, fig. 19.

2008 Pandorinellina exigua philipi (Klapper). - Kim et al., pl. 20, fig. 12, pl. 24, figs 10, 11.

2012 Pandorinellina philipi (Klapper). - Baranov, pl. 1, figs 26-29, pl. 4, figs 20, 21.

2013 Pandorinellina exigua philipi (Klapper). - Mavrinskaya \& Slavík, fig. $6 \mathrm{H}$.
2016 Pandorinellina exigua philipi (Klapper). - Lu et al., p. 281, fig. 3L-P.

Remarks. - This subspecies is easily distinguished from $P$. e. exigua by the latter having a less restricted basal cavity. Pandorinellina exigua philipi was first recognised by Klapper (1969) from Royal Creek in the Yukon Territory, Canada, in horizons dated as sulcatus Zone, and has been reported from Solo Creek also in the Yukon Territory (Fåhraeus 1971). Elsewhere in continental North America, P. e. philipi has been recognised in Alaska by Lane \& Ormiston (1979), Savage (1977) and Savage et al. (1977). Outside of continental North America it has been reported in eastern Australia by Pedder et al. (1970), Mawson et al. (1992), Wilson (1989) and Colquhoun (1995), and from Central Asia by Apekina \& Mashkova (1978), Bardashev \& Ziegler (1992) and Sobolev (1994). From these occurrences, this subspecies appears to have an age range from sulcatus Zone to perbonus Zone.

Mawson (in Talent et al. 2000) noted that Kimognathus, a monospecific conodont genus found in the pesavis Zone in terranes now located in Tadjikistan, Uzbekistan, Australia and Arctic North America, may be taken as indicative of former close juxtaposition of the crustal blocks in question or the former existence of circulation patterns facilitating migration between these blocks. It was also shown (Talent et al. 2000) that restricted distribution of certain conodont species occurred in the pireneae and dehiscens intervals. From the occurrences noted above for subspecies of $P$. exigua such endemism also occurred in the sulcatus and kindlei zones.

\section{Pandorinellina steinhornensis miae (Bultynck, 1971)} Figure 21Q-Z

1971 Spathognathodus steinhornensis miae; Bultynck, pp. 25-31, pl. 4, figs 13-20, pl. 5, figs 1-14.

Figure 30. A-G - Coryssognathus dubius (Rhodes, 1953). • A - oblique anterior views of Sa element MMMC 4648 from Myola $1 . \cdot \mathrm{B}-\mathrm{oblique}$ anterior view of Sb element MMMC 4649 from Myola 2. $\bullet \mathrm{C}-$ oblique anterior view of Pb element MMMC 4650 from Myola $2 . \bullet \mathrm{D}-\mathrm{oblique}$ lateral view of Pc element MMMC 4651 from Myola 1. E - oblique anterior view of Pc element MMMC 4652 from Myola $1 . \bullet \mathrm{F}-$ lateral view of M element MMMC 4653 from Myola 2. • G - anterior view of M element MMMC 4654 from Myola 5. • H-J - Pelekysgnathus sp. A? Corriga \& Corradini, 2009. $\bullet \mathrm{H}$ - lateral view of Pa element MMMC 4655 from Myola 2. • I - lateral view of Pa element MMMC 4656 from Myola 4. $\bullet$ J - lateral view of Pa element MMMC 4657 from Myola 2. • K, L - Erika divarica Murphy \& Matti, 1983. • K - lateral view of Sb/Pb element MMMC 4658 from Myola 4. $\bullet \mathrm{L}$ - lateral view of Sb/Pb element MMMC 4659 from Myola 2. $\bullet$ M - Oulodus elegans detorta? (Walliser, 1964), lateral view of Sb element MMMC 4660 from Myola 2. $・ \mathrm{~N}-\mathrm{Q}-$ Ozarkodina confluens (Branson \& Mehl, 1933). $\bullet \mathrm{N}-$ lateral view of partial Pb element MMMC 4661 from Myola 2. • O - lateral view of Pa element MMMC 4662 from Myola 0. • P - lateral view of Pa element MMMC 4663 from Myola 3. - Q - lateral view of Pa element MMMC 4664 from Myola 2. $\bullet$ R-V - Ozarkodina crispa (Walliser, 1964). $\bullet$ R - upper view of Sa element MMMC 4665 from Myola 0. $\bullet$ S - upper view of Sa element MMMC 4666 from Myola 1. • T - lateral view of Pa element MMMC 4667 from Myola 1. - U - lower view of Pa element MMMC 4668 from Myola 1. • V - upper view of Pa element MMMC 4669 from Myola 4 . $\bullet$ W, X - Ozarkodina excavata excavata (Branson \& Mehl, 1933). $\bullet W$ - lateral view of juvenile Pa element MMMC 4670 from Myola $1 . \bullet X-1$ ateral view of Pa element MMMC 4671 from Myola 5. Scale bar $=0.1 \mathrm{~mm}$. 


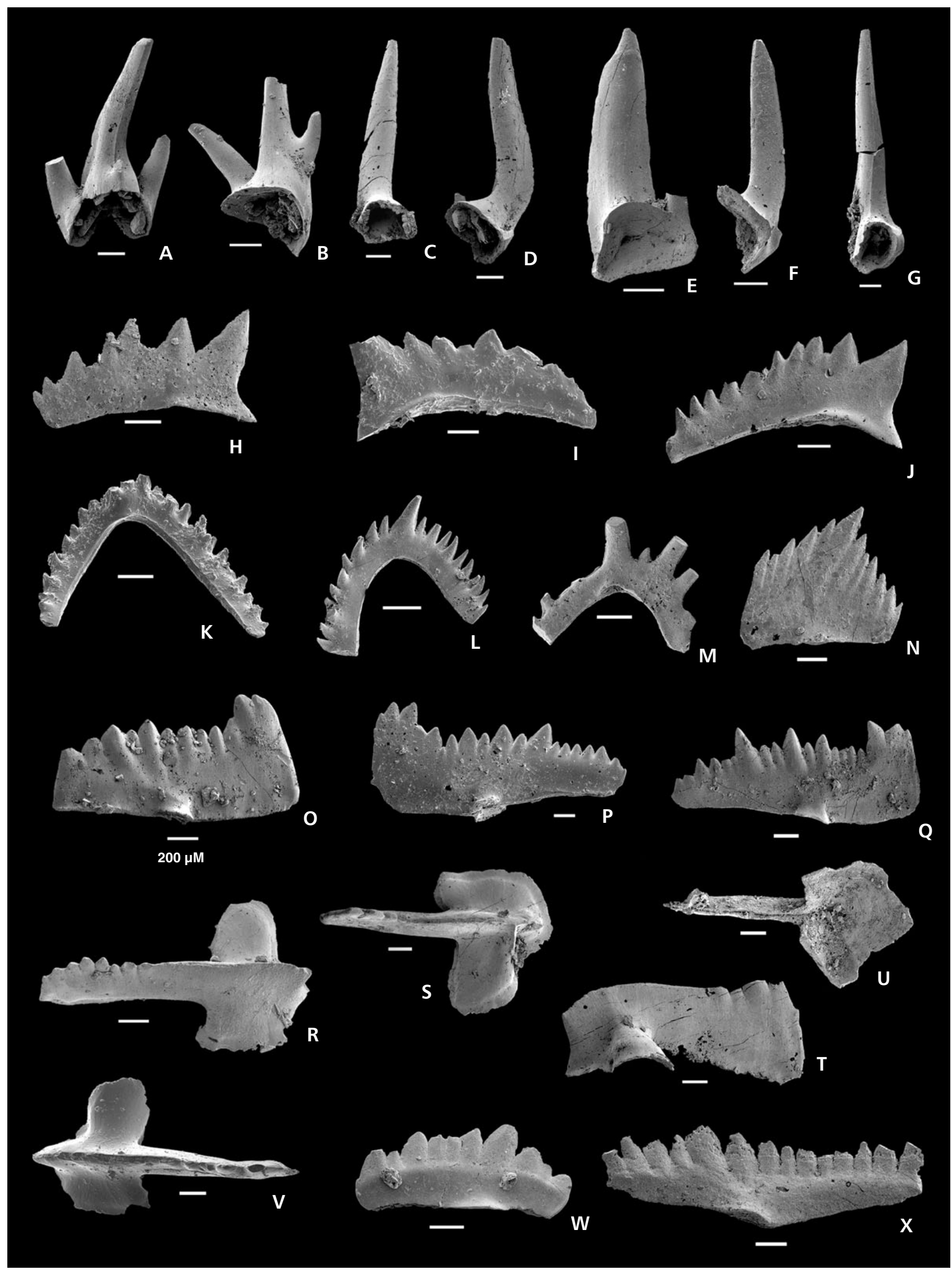




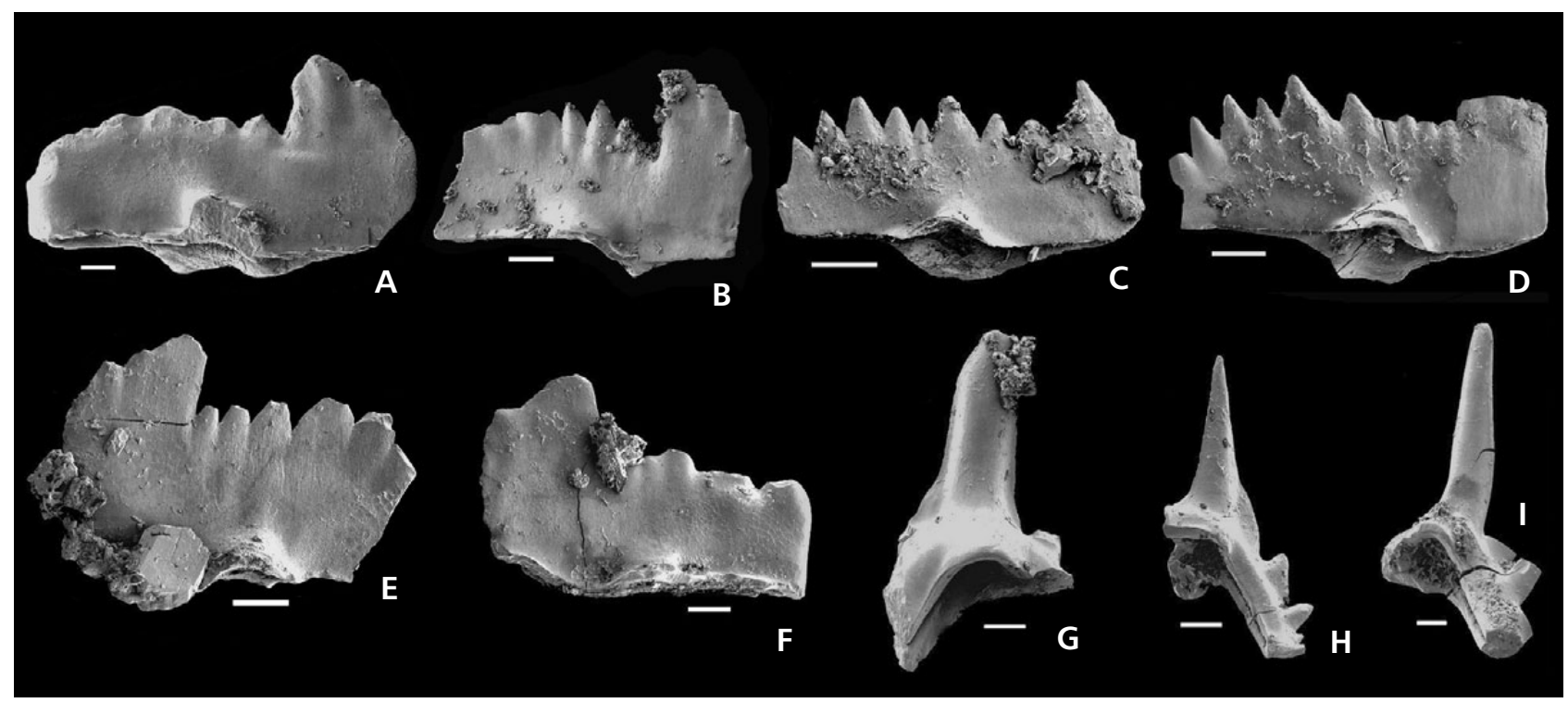

Figure 31. Conodont elements from Troffs sample. • A-F - Pandorinellina exigua philipi (Klapper, 1969), Pa elements. • A - lateral view of MMMC 4672. • B - lateral view of MMMC 4673. • C - lateral view of MMMC 4674. • D - lateral view of MMMC 4675. $\bullet$ E lateral view of MMMC 4676. - F- lateral view of MMMC 4677. • G-I - cf. Oulodus sp. B in Mawson et al., 1992, broken M elements. $\bullet \mathrm{G}-$ lateral view of MMMC 4678. $\bullet$ H - oblique lateral view of MMMC 4679. $\bullet$ I - oblique lateral view of MMMC 4680. Scale bar $=0.1 \mathrm{~mm}$.

1980 Pandorinellina steinhornensis miae (Bultynck). Klapper \& Johnson, p. 451; see for additional synonymy.

1990 Ozarkodina steinhornensis miae (Bultynck). - Bultynck, pl. 6, figs 10, 11.

1990 Pandorinellina steinhornensis miae (Bultynck). García-López et al., pl. 1, figs 21-23.

1991 Pandorinellina steinhornensis praeoptima (Mashkova) sensu Lane \& Ormiston 1979. - Uyeno, pl. 21, fig. 19.

1992 Pandorinellina miae (Bultynck). - Bardashev \& Ziegler, pl. 1, figs 41, 47.

1994 Pandorinellina steinhornensis miae (Bultynck). Mawson \& Talent, pp. 55-57, fig. 11A-G.

1995 Pandorinellina steinhornensis miae (Bultynck). Furey-Greig, pl. 1, fig. 18.

1995 Pandorinellina steinhornensis miae (Bultynck). Colquhoun, pl. 2, figs 7-9.

1999 Pandorinellina steinhornensis miae (Bultynck). Talent \& Mawson, pl. 5, figs 19-24, pl. 12, figs 11-13.

1999 Ozarkodina steinhornensis miae (Bultynck). - Benfrika, p. 316, pl. 1, fig. 19.

2003 Pandorinellina cf. miae (Bultynck). - Farrell, p. 150 , pl. 12, figs 5,6 .

2003 Pandorinellina steinhornensis miae (Bultynck). Sloan, pl. 2, figs 22-24.

2004b Ozarkodina steinhornensis miae (Bultynck). - Slavík, fig. 11.7-11.11.

2004 Pandorinellina miae (Bultynck). - Farrell, p. 976, pl. 10, figs 10-13.
2007 Pandorinellina miae (Bultynck). - Suttner, pp. 44-45, pl. 20, fig. 7.

2008 Pandorinellina steinhornensis miae (Bultynck). Gaetani et al., pl. 1, figs 2, 10.

2009 Ozarkodina steinhornensis miae (Bultynck). Martín-Algarra et al., fig. 8.11, 8.12.

2012 Pandorinellina miae (Bultynck). - Baranov, pl. 2, figs 6-9.

2016 Pandorinellina steinhornensis miae (Bultynck). Lu et al., pp. 281-283, fig. 3Q.

Remarks. - This form was originally described from Spanish collections dated as dehiscens Zone (Bultynck 1971). Mawson \& Talent (1994) obtained 694 specimens from sampled sections of sulcatus-kindlei age at Tyers and Boola in east-central Victoria, Australia. Although it has a more centrally situated basal cavity, one specimen from GUND 3 (Fig. 21Y, Z) is included here with P. s. miae as an abberant form.

Family unknown

\section{Heliagnathus gen. nov.}

Type species. - Heliagnathus parvilabiatus sp. nov.

Etymology. - Helias, daughter of the Greek god Helios, and gnathus (Greek), jaw, in reference to the hemi-sun-like arrangement of denticles of the $\mathrm{Pa}, \mathrm{Pb}$ and $\mathrm{Sa}$ elements of the apparatus. 


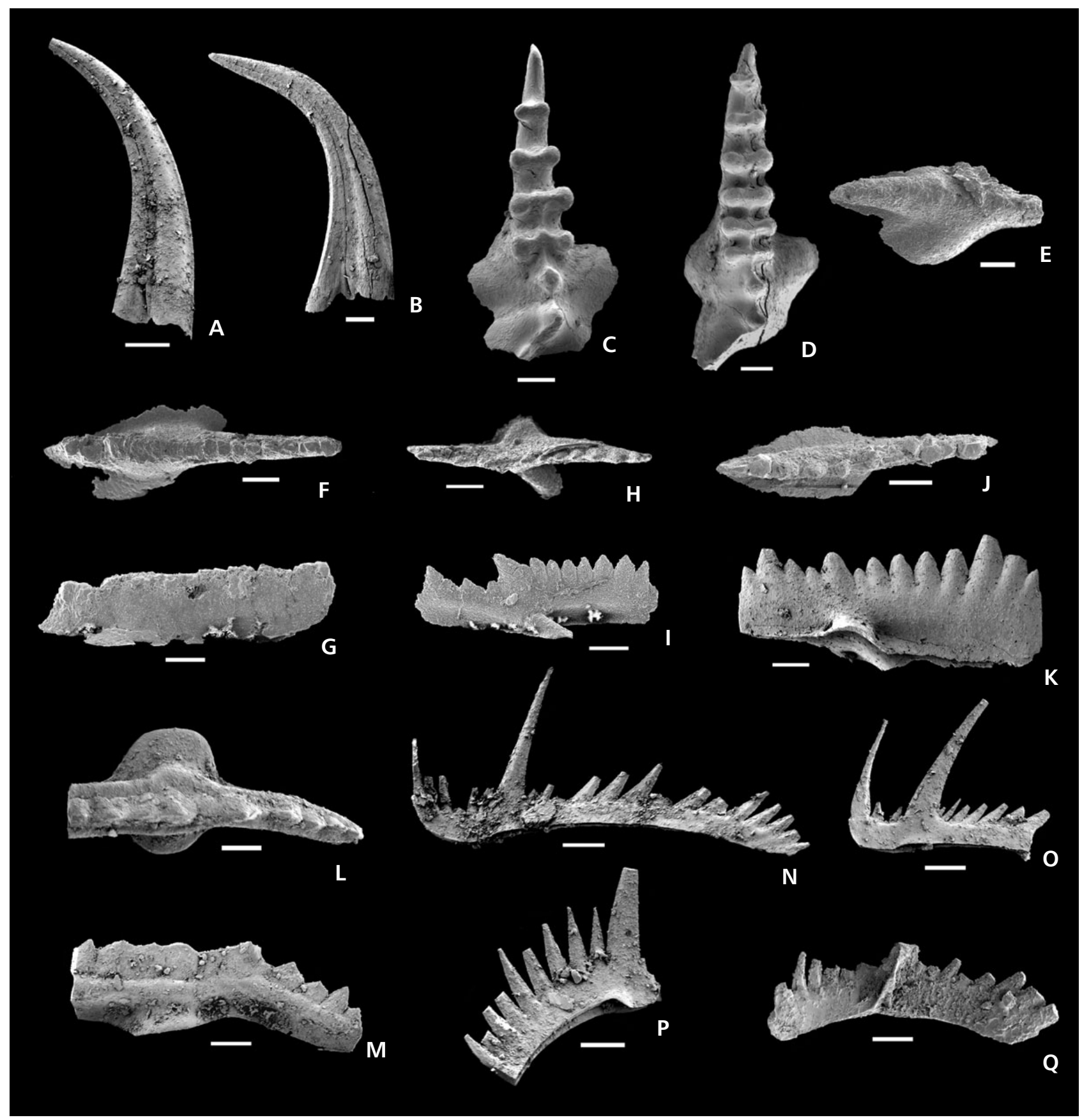

Figure 32. Conodont elements from Trundle sample. • A, B - Panderodus unicostatus (Branson \& Mehl, 1933). A - lateral view of Sa element MMMC 4681. B - lateral view of Sb element MMMC 4682. $\bullet$ C, D - Icriodus ampliatus sp. nov. $\bullet \mathrm{C}$ - upper view of I element MMMC $4683 . \bullet \mathrm{D}-$ upper view of I element MMMC 4684. • E-G - Eognathodus sulcatus lanei subsp. nov. $\bullet$ E - oblique upper view of damaged specimen MMMC 4685. • F, G - upper and lateral views of Pa element MMMC 4686. • H, I - Ozarkodina paucidentata Murphy \& Matti, 1983, upper and lateral views of Pa element MMMC 4687. - J - Ozarkodina selfi lanceola subsp. nov., upper view of Pa element MMMC 4688. $・ \mathrm{~K}-$ Ozarkodina remscheidensis remscheidensis (Ziegler, 1960), lateral view of Pa element MMMC 4689. $\bullet$ L-Q-Ozarkodina excavata excavata (Branson \& Mehl, 1933). $\bullet$ L, M - upper and lateral views of damaged Pa element MMMC 4690. $\bullet$ N - lateral view of Sc element MMMC 4691. O - lateral view of Sc element MMMC 4692. $\cdot \mathrm{P}$ - lateral view of M element MMMC 4693. $\cdot \mathrm{Q}$ - lateral view of Sb element MMMC 4694. Scale bar $=0.1 \mathrm{~mm}$.

Diagnosis. - A seximembrate apparatus with P positions occupied by carminate and alate elements, a dolabrate $\mathrm{M}$ element and a symmetry-transition series consisting of alate, digyrate and bipennate elements. All elements are characterised by having short, tightly spaced denticles set on relatively wide processes and, in many cases, arranged symmetrically, giving a hemi-sun-like appearance. 
Occurrence. - Lower Devonian (Pragian), sulcatus to pireneae zones.

Heliagnathus parvilabiatus sp. nov. Figure 28J-S

Holotype. - Pa element, specimen MMMC 4625 (Fig. 28J, K), from MDAM 31.

Type locality and horizon. - Sample MDAM 31 from the Mountain Dam Limestone Member on "Marobee" station, approximately $90 \mathrm{~km} \mathrm{NW}$ of Condobolin, central New South Wales.

Etymology. - Parvus (Latin), and labiatus (Latin), lipped, in reference to the small, restricted basal cavity common to many elements of the apparatus.

Diagnosis. - As for genus.

Description. - Pa element symmetrically fan-shaped with small, free denticles diminishing in height from above the basal cavity towards the anterior and posterior extremities of the unit. The arrangement of the denticles is reminiscent of a half-exposed, rising or setting sun. Basal cavity small, expanded beneath the main denticle, thereafter becoming tightly restricted to become a groove extending to the anterior and posterior of the unit.

$\mathrm{Pb}$ element symmetrical with a high main cusp and two enlarged denticles to the anterior and posterior with three or four small, free denticles continuing to the anterior and posterior of the unit. Basal cavity expanded beneath the main denticle, thereafter becoming tightly restricted to become a groove extending to the anterior and posterior.

$\mathrm{M}$ element has an apparently robust main denticle (the one specimen found in this study has a broken main denticle but the breakage point shows the base of such a denticle). The wide processes have small, evenly spaced denticles along both. Expansion of basal cavity is restricted to below main cusp, thereafter running as a groove to the extremities of the unit.

Symmetry transition series consists of alate, digyrate and bipennate elements, all with wide processes with evenly spaced, free denticles. All elements have smaller basal cavities expanded beneath the main cusp compared to the $\mathrm{Pa}, \mathrm{Pb}$ and $\mathrm{M}$ elements; the cavity continues as a groove towards the extremities of the units. The Sa element has an extremely large and high main denticle with contrastingly tiny denticles developed on each process and is spectacularly distinguished by the penultimate denticle of both processes being greatly enlarged, mimicking the development of the two denticles on either side of the main cusp in the $\mathrm{Pb}$ element. The basal cavity of the Pa element has prominent "lips". The Sb and Sc elements have a large main cusp with the other denticles similar to those of the other elements.

Remarks. - The designated $\mathrm{Pb}$ element for the apparatus (Fig. 28L) bears some resemblance to the Sa element of Amydrotaxis johnsoni (see Klapper \& Murphy 1980, fig. 3.13) and to the ?Sa element of the Ludlow Apparatus A of Uyeno (1980, p. 48, pl. 9, fig. 3), but has a more restricted basal cavity and a greater number of denticles set on a broader blade and, additionally, has three or more prominent medial denticles.

\section{Genus and species unknown}

\section{Apparatus A}

Figure 29A-I

Remarks. - A small number of distinctive elements were recovered from the Mountain Dam Formation. They are characterised by thick angulate blades, stout triangular denticles, a small but flared basal cavity and a distinctive asymmetry on either side of the cusp. Many of these elements (e.g. Fig. 29A, B) are only very slightly bowed, whereas others are bowed more strongly (e.g. Fig. 29C). They probably occupied one of the $\mathrm{P}$ positions in the apparatus. These elements have some similarity to those of the Silurian genus Ctenognathodus but they are left in open nomenclature here because of their small numbers.

\section{Acknowledgements}

David Alder and Noreen Clark, then employed in the petroleum exploration section of the Geological Survey of New South Wales, drew our attention to carbonate horizons within the Devonian sequences of the Darling Basin that they suspected might yield biostratigraphically useful and even age-constraining information, and went to considerable trouble to provide us with samples for acid-leaching from various bores in the basin. Soon thereafter, Evan Leitch, formerly of the University of Technology Sydney, sent a limestone sample (B 16L herein) to Ruth Mawson and John Talent. This sample, from a small area of outcrop of the Booth Limestone on the Multagoona Anticline on "Manuka" station, proved unexpectedly productive of well-preserved conodonts. This prompted a Masters investigation by one of us (Mathieson), completed in 2006, which subsequently expanded into a much greater regional investigation incorporating additional field investigations. The project benefited greatly from Peter Molloy's expertise with the acid-leaching of numerous samples, Ron Oldfield's expert guidance in optical microscopy and Deborah Birch's skill with a near-gerontic Scanning Electron Microscope. Dean Oliver used his amazing skill of turning mud-map drawings into elegant text-figures. Stuart and Nancy Moseley of "Manuka", Diane Whiteman of "The Rookery", John, Linda and Dino Mekrizis of "The Bluff", and David and Pam Smith of 
"Marobee" generously allowed access to their properties to collect samples, provided stimulating conversation, and numerous re-invigorating cups of tea. The New South Wales National Parks and Wildlife Service obligingly gave permission to sample in the Stoney Tank area of the Gundabooka National Park. Ian Percival, Geological Survey of New South Wales, assisted with providing access to subsurface cores through relevant horizons. The project in the earlier phase as a Masters dissertation was facilitated by two research grants: a postgraduate one from Macquarie University, and another from the Joyce Vickery Fund of the Linnean Society of New South Wales. We thank colleagues at the Geological Survey of New South Wales for access to much unpublished data that greatly assisted with this project and opens up new research opportunities to build on this work.

We extend sincere thanks to the two reviewers Ladislav Slavík and John Pickett who through a combination of international perspectives and deep local knowledge were able to make constructive comments and suggestions about both the minutiae and global picture that urged us to rethink the structure of the manuscript leading to a greatly improved final result. Our thanks also to our patient handling editor David Holloway for his meticulous work in facilitating the coherence and logic of the final product.

We are grateful to our MUCEP friends and colleagues over many years for their good cheer, encouragement and lively engagement when our own "liveliness" was flagging. We specifically thank Peter Cockle, Michael Engelbretsen, James Valentine and George Wilson for numerous courtesies with the computer and in the acid-leaching facility that helped the project towards completion.

\section{References}

Alder, J.D., Bembrick, C., Hartung-Kragi, B., Mullard, B., Pratt, D.A., ScotT, J. \& Shaw, R.D. 1998. A reassessment of the petroleum potential of the Darling Basin: a Discovery 2000 initiative. Australian Petroleum Production and Exploration (APPEA) Journal 38, 278-310.

Apekina, L.S. \& Mashrova, T.V. 1978. Conodonta, 73-78. In Sokolov, B.S. \& Garkovets, V.G. (eds) Tipovye razrezy pogranichnykh sloev nizhnego devon Sredney Azii. Pytevoditel' ekskursiy. Polevaya sessiya Mezhdunarodnoy podkomissii po stratigrafii devona, g. Samarkanda, SSSR, avgust 1978. Atlas paleontologicheskikh tablits. Ministry of Geology, Uzbek SSR, Tashkent.

Armstrong, H.A. 1990. Conodonts from the Upper Ordovician-lower Silurian carbonate platform of North Greenland. Bulletin Grønlands Geologiska Undersøgelse 159, 1-151.

BARANOV, V.V. 2012. Lower Devonian conodont zonation in arctic regions of Eurasia. Stratigraphy and Geological Correlation 20(2), 179-198. DOI 10.1134/S0869593812010029

Barca, S., Corradini, C., Ferretti, A., Oliviera, R. \& Serpagli, E. 1995. Conodont biostratigraphy of the "Ockerkalk" (Silurian) from southeastern Sardinia. Rivista Italiana di Paleontologia i Stratigrafia 100(4), 459-476. [Imprint 1994]

BARDASHev, I. 1991. Devonskaya sistema. Konodonty, 214-245. In Jalilov, M.R. (ed.) Atlas iskopaemoi fauny i flory Tadzhikistana: ordovik, silur, devon. Donish, Dushanbe. [Imprint 1990]
Bardashev, I.A., Weddige, K. \& Ziegler, W. 2002. The polymorphogenesis of some Early Devonian platform conodonts. Senckenbergiana lethaea 82, 375-451.

BARDASHEV, I. \& ZiEGLER, W. 1992. Conodont biostratigraphy of Lower Devonian deposits of the Shishkat Section (southern Tien-Shan, Middle Asia). Courier Forschungsinstitut Senckenberg 154, 1-29.

BARRICK, J.E. 1977. Multi-element simple-cone conodonts from the Clarita Formation (Silurian), Arbuckle Mountains, Oklahoma. Geologica et Palaeontologica 11, 47-68.

Barrick, J.E., Klapper, G., KlefFner, M.A. \& Karlsson, H.R. 2010. Conodont biostratigraphy and stable isotope chemostratigraphy of the lower Henryhouse Formation (Gorstian-early Ludfordian, Ludlow, Silurian), southern Oklahoma, USA. Memoirs of the Association of Australasian Palaeontologists 39, 51-70.

BASSLER, R.S. 1925. Classification and stratigraphic use of the conodonts. Bulletin of the Geological Society of America 36, 218-220.

Becker, R.T., Gradstein, F.M. \& Hammer, O. 2012. The Devonian Period, 559-601. In Gradstein, F.M., OGG, J.G., Schmitz, M.D. \& OGG, G.M. (eds) The Geologic Timescale 2012. Volume 2. Elsevier, Amsterdam.

Benfrika, E.M. 1999. Some upper Silurian-Middle Devonian conodonts from the northern part of Western Meseta of Morocco: systematic and palaeogeographical relationships. Bollettino della Società Paleontologica Italiana 37(2-3), 311-319.

Benfrika, E.M., Bultynck, P. \& Hassani, A.E. 2007. Upper Silurian to Middle Devonian conodont faunas from the Rabat-Tiflet area (northwestern Morrocan Meseta). Geological Quarterly 51(4), 393-406.

Bergström, S. \& Sweet, W. 1966. Conodonts from the Lexington Limestone (Middle Ordovician) of Kentucky and its lateral equivalent in Ohio and Indiana. Bulletin of American Paleontology 50, 257-441.

Berkyová, S. 2009. Lower-Middle Devonian (upper Emsian-Eifelian, serotinus-kockelianus zones) conodont faunas from the Prague Basin, the Czech Republic. Bulletin of Geosciences 84(4), 667-686. DOI 10.3140/bull.geosci.1153

Bischoff, G.C. \& Argent, J.C. 1990. Lower Devonian (late Lochkovian-Pragian) limestone stratigraphy at [sic] conodont distribution, Waratah Bay, Victoria. Courier Forschungsinstitut Senckenberg 118, 441-471.

Bischoff, G.C.O. \& Sannemann, D. 1958. Unterdevonische Conodonten aus dem Frankenwald. Notizblatt des Hessischen Landesamtes für Bodenforschung zu Wiesbaden 86, 87-110.

Boncheva, I., GöncüoĞlu, M.C., Leslie, S.A., Lakova, I., SAchanski, V., SAYdam, G., Gedik, I. \& Königshof, P. 2009. New conodont and palynological data from the Lower Palaeozoic in Northern Çamdağ, NW Anatolia, Turkey. Acta Geologica Polonica 59(2), 157-171.

Branson, E.B. \& Mehl, M.G. 1933. Conodont studies No. 1: Conodonts from the Harding Sandstone of Colorado; Bainbridge (Silurian) of Missouri; Jefferson City (Lower Ordovician) of Missouri. University of Missouri Studies 8(1), 7-72.

Branson, E.B. \& Mehl, M.G. 1938. The conodont genus Icriodus and its stratigraphic distribution. Journal of Paleontology 12, 156-166.

Brime, C., Talent, J.A. \& Mawson, R. 2003. Low-grade metamorphism in the Palaeozoic sequences of the Townsville hinterland, northeastern Australia. Australian Journal of Earth 
Sciences 50(5), 751-767.

DOI 10.1111/j.1440-0952.2003.01023.x

Brown, C.M., Jackson, K.L., Lockwood, K.L. \& PAssmore, V.L. 1982. Source rock potential and hydrocarbon prospectivity of the Darling Basin, NSW. BMR Journal of Australian Geology and Geophysics 7, 23-33.

BULTYNCK, P. 1971. Le Silurien supérieur et le Dévonien inférieur de la Sierra de Guadarrama (Espagne centrale). Deuxième partie: assemblages de conodontes à Spathognathodus. Bulletin de l'Institut royal des sciences naturelles de Belgique 47(3), 1-43.

BulTynck, P. 1976. Le Silurien supérieur et le Dévonien inférieur de la Sierra de Guadarrama (Espagne centrale). Troisième partie: éléments Icriodiformes, Pelekysgnathiformes et Polygnathiformes. Bulletin de l'Institut royal des sciences naturelles de Belgique, Série sciences de la terre 5, 1-74.

Bultynck, P. 1990. Conodonts from the La Grange Limestone (Emsian), Armorican Massif, north-western France. Courier Forschungsinstut Senckenberg 117, 173-203.

Bultynck, P. 2007. Limitations on the application of the Devonian standard conodont zonation. Geological Quarterly 51(4), 339-344.

Burrow, C.J. 2003. Earliest Devonian gnathostome microremains from central New South Wales (Australia). Geodiversitas 25(2), 273-288.

Burrow, C.J. 2006. Placoderm fauna from the Connemarra Formation (?late Lochkovian, Early Devonian), central New South Wales, Australia. Alcheringa Supplement 1, 59-88. DOI 10.1080/03115510609506856

CAReY, S.P. \& Bolger, P.F. 1995. Conodonts of disparate Lower Devonian zones, Wilson Creek Shale, Tyers-Walhalla area, Victoria, Australia. Alcheringa 19, 73-86. DOI 10.1080/03115519508619099

CARLS, P. 1969. Die Condonten des tieferen Unterdevons der Guadarrama (Mittel-Spanien) und die Stellung des Grenzbereiches Lochkovium/Pragium nach der rheinischen Gliederung. Senckenbergiana lethaea 50, 303-355.

CARLS, P. 1975. Zusätzliche Conodonten-Funde aus dem tieferen Unter-Devon Keltiberiens (Spanien). Senckenbergiana lethaea 56, 399-428.

CARLS, P. \& GANDL, J. 1969. Stratigraphie und Conodonten des Unter-Devons der östlichen Iberischen Ketten (NE-Spanien). Neues Jahrbuch für Geologie und Paläontologie, Abhandlungen 132(2), 155-218.

Carls, P., Slavík, L. \& ValenZuela-Ríos, J.I. 2007. Revisions of conodont biostratigraphy across the Silurian-Devonian boundary. Bulletin of Geosciences 82(2), 145-164. DOI 10.3140/bull.geosci.2007.02.145

Carls, P., Slavík, L. \& Valenzuela-Ríos, J.I. 2008. Comments on the GSSP for the basal Emsian stage boundary. Bulletin of Geosciences 83(4), 383-390. DOI 10.3140/bull.geosci.2008.04.383

Chatterton, B.D.E. 1979. Aspects of Late, Early and mid Devonian biostratigraphy of western and northwestern Canada. Geological Society of Canada Special Paper 18, 131-161.

Chlupáč, I., Lukeš, P., PARis, F. \& SchÖNlaub, H.P. 1985. The Lochkovian-Pragian boundary in the Lower Devonian of the Barrandian. Jahrbuch der geologischen Bundesanstalt 128, 9-41.

Chlupéč, I. \& Oliver, W.A. Jr. 1989. Decision on the Lochkovian-Pragian Boundary Stratotype (Lower Devonian). Episodes 12(2), 109-113.
COCKLE, P. 1999. Conodont data in relation to time, space and environmental relationships in the Silurian (late Llandovery-Ludlow) succession at Boree Creek (New South Wales, Australia). Abhandlungen der Geologischen Bundesanstalt 54, 107-133.

Colquhoun, G.P. 1995. Early Devonian conodont faunas from the Capertee High, NE Lachlan Fold Belt, southeastern Australia. Courier Forschungsinstitut Senckenberg 182, 347-369.

Cooney, P.M. \& Mantaring, A.M. 2007. The petroleum potential of the Darling Basin, 216-235. In Munson, T.J. \& Ambrose, G.J. (eds) Proceedings of the Central Australian Basins Symposium (CABS), Alice Springs, Northern Territory, 16-18 August 2005. Northern Territory Geological Survey, Special Publication 2.

COOPER, B.J. 1973. Lower Devonian conodonts from Loyola, Victoria. Proceedings of the Royal Society of Victoria 86, $77-84$.

CoOPER, B.J. 1975. Multi-element conodonts from the Brassfield Limestone (Silurian) of southern Ohio. Journal of Paleontology 49, 984-1008.

COOPER, B.J. 1977. Upper Silurian conodonts from the Yarrangobilly Limestone, southeastern New South Wales. Proceedings of the Royal Society of Victoria 89, 183-194.

Corradini, C. 2008. The conodont genus Pseudooneotodus Drygant from the Silurian and Lower Devonian of Sardinia and the Carnic Alps (Italy). Bolletino della Società Paleontologica Italiana 46(2-3), 139-148.

Corradini, C. \& Corriga, M.G. 2010. Silurian and lowermost Devonian conodonts from the Passo Volaia area (Carnic Alps, Italy). Bollettino della Società Paleontologica Italiana 49(3), 237-253.

Corradini, C. \& Corriga, M.G. 2012. A Přídolí-Lochkovian conodont zonation in Sardinia and the Carnic Alps: implications for a global zonation scheme. Bulletin of Geosciences 87(4), 635-650. DOI 10.3140/bull.geosci.1304

Corradini, C., Ferretti, A. \& Serpagli, E. 1998a. Wenlock and Pridoli conodonts from Argiola, East of Domusnovas. Giornale di Geologia, series 3a 60, 194-198.

Corradini, C., Ferretti, A., Serpagli, E. \& Barca, S. 1998 b. The Ludlow-Pridoli section "Genna Ciuerciu”, west of Silius. Giornale di Geologia, series 3a 60, 112-118.

Corradini, C. \& Serpagli, E. 1999. A Silurian conodont biozonation from late Llandovery to end Pridoli, Sardinia (Italy), 255-273. In Serpagli, E. (ed.) Proceedings of the Seventh European Conodont Symposium. Bollettino della Società Paleontologica Italiana 37(2-3). [Imprint 1998]

Corriga, M.G. \& Corradini, C. 2009. Upper Silurian and Lower Devonian conodonts from the Monte Cocco II Section (Carnic Alps, Italy). Bulletin of Geosciences 84(1), 155-168. DOI 10.3140/bull.geosci.1112

Corriga, M.G., Corradini, C. \& Ferretti, A. 2009. Silurian conodonts from Sardinia: an overview. Rendiconti della Società Paleontologica Italiana 3(1), 95-107.

Corriga, M.G., Corradini, C., Pondrelli, M. \& Simonetto, L. 2012. Lochkovian (Lower Devonian) conodonts from Rio Malinfier Section (Carnic Alps, Italy). Gortania. Geologia, Paleontologia, Paletnologia 33, 31-38.

Corriga, M.G., Corradini, C. \& Walliser, O.H. 2014. Upper Silurian and Lower Devonian conodonts from Tafilalt, southeastern Morocco. Bulletin of Geosciences 89(1), 183-200. DOI 10.3140/bull.geosci.1473

Corriga, M.G., Suttner, T.J., Corradini, C., Kido, E., 
Pondrelli, M. \& Simonetto, L. 2011. The age of the La Valute limestone-Findenig limestone transition in the La Valute Section (Mount Zermula area, Carnic Alps). Gortania. Geologia, Paleontologia, Paletnologia 32, 5-12.

Curran, J.M. 1888. Carboniferous and Silurian fossils from central New South Wales. Proceedings of the Linnean Society of New South Wales 3, 800-804.

DAhlqvist, P. \& Bergström, S.M. 2005. The lowermost Silurian of Jämtland, central Sweden: conodont biostratigraphy, correlation and biofacies. Transactions of the Royal Society of Edinburgh: Earth Sciences 96, 1-19. DOI $10.1017 /$ S0263593300001218

DANiELL, J.J. 2003. Sedimentology, conodont biostratigraphy, and palaeogeography of a mid-Devonian carbonate/siliciclastic platform margin, Broken River region, north-eastern Australia. Courier Forschungsinstitut Senckenberg 245, 327-355.

De Deckker, P. 1976. Late Silurian (late Ludlovian) conodonts from the Kildrummie Formation, south of Rockley, New South Wales. Journal and Proceedings of the Royal Society of New South Wales 109, 59-69.

Dongal, G.M.S. 1995. Early Devonian (Pragian and early Emsian) fauna from the eastern Tamworth Terrane, New South Wales. Memoirs of the Association of Australasian Palaeontologists 18, 131-142.

Donoghue, P.J.C., Purnell, M.A., Aldridge, R.J. \& Zhang, S. 2008. The interrelationships of "complex" conodonts (Vertebrata). Journal of Systematic Palaeontology 6(2), 119-153. DOI 10.1017/S1477201907002234

DrucE, E.C. 1971. Conodonts from the Garra Formation (Lower Devonian), New South Wales. Bulletin of the Bureau of Mineral Resources, Geology and Geophysics 116, 29-64. [Imprint 1970]

Drygant, D. 1974. Prostye konodonty silura i nizov devona Volyno-Podol'ya [Simple conodonts from the Silurian and lowermost Devonian of Volyno-Podolia]. Palaeontologicheskii sbornik 10, 64-70.

DRYGANT, D. 2010. Devonian conodonts from south-west margin of the East European Platform (Volyn'-Podolian Ukraine). $156 \mathrm{pp}$. Academperiodyka, Kyiv. [in Ukrainian]

Drygant, D. \& SzANIAWSKI, H. 2012. Lochkovian conodonts from Podolia, Ukraine, and their stratigraphic significance. Acta Palaeontologica Polonica 57(4), 833-861. DOI 10.4202/app.2012.0124

DzIK, J. 1976. Remarks on the evolution of Ordovician conodonts. Acta Palaeontologica Polonica 21, 395-455.

EikhVALD, L.P. 2008. Devonian conodonts of the Amur region. Russian Journal of Pacific Geology 2(3), 244-254. DOI 10.1134/S1819714008030056

Ethington, R.L. 1959. Conodonts from the Ordovician Galena Formation. Journal of Paleontology 33(2), 257-292.

FÂrRAEUS, L.E. 1971. Lower Devonian conodonts from the Michelle and Prongs Creek formations, Yukon Territory. Journal of Paleontology 45, 665-683.

FARRELL, J.R. 2003. Late Pridolian, Lochkovian and early Pragian conodonts from the Gap area between Larras Lee and Eurimbla, central western NSW, Australia. Courier Forschungsinstitut Senckenberg 245, 107-181.

FARRELL, J.R. 2004. Siluro-Devonian conodonts from the Camelford Limestone, Wellington, New South Wales, Australia. Palaeontology 47(4), 937-982.

DOI 10.1111/j.0031-0239.2004.00394.x
FARReLl, J.R. 2006. Pridoli conodont fauna from tectonically emplaced limestone blocks within the Barnby Hills Shale, central western New South Wales. Alcheringa 30(2), 233-249. DOI 10.1080/03115510608619315

Felton, E.A. 1981. Geology of the Canbelego 1:100 000 sheet 8134. viii +171 pp. Geological Survey of New South Wales, Sydney.

Ferretti, A., Corradini, C. \& Serpagli, E. 1998. Wenlock-Ludlow conodonts from Perd'e Fogu (Fluminimaggiore). Giornale di Geologia, series $3 a$ 60, 156-167.

FölDVARY, G.Z. 2000. Siluro-Devonian invertebrate faunas from the Bogan Gate-Trundle-Mineral Hill area of central New South Wales. Records of the Western Australian Museum Supplement 58, 81-102.

FureY-GrieG, T.M. 1995. The "Nemingha" and "Loomberah" limestones (Early Devonian; Emsian) of the Nemingha-Nundle area, northern New South Wales: conodont data and inferred environments. Courier Forschungsinstitut Senckenberg 182, 217-233.

FUREY-GRIEG, T.M. 2000. Late Ordovician (Eastonian) conodonts from the Early Devonian Drik Drik Formation, Woolomin area, eastern Australia. Records of the Western Australian Museum Supplement 58, 133-143.

Gaetani, M., Mawson, R., Sciunnach, D. \& Talent, J.A. 2008. The Devonian of the Western Karakorum (Pakistan). Acta Geologica Polonica 58(3), 261-285.

GARCÍA-LóPEZ, S., JAHNKE, H. \& SANZ-LóPEZ, J. 2002. Uppermost Pridoli to upper Emsian stratigraphy of the Alto Carrión Unit, Palentine Domain (northwest Spain), 229-257. In García-López, S. \& BAStidA, F. (eds) Palaeozoic conodonts from northern Spain, Cuardernos del Museo Geominero No. 1. Instituto Geológico y Minero de España, Madrid.

García-López, S., Julivert, M., Soldevila, J., Truyols-MasSONI, M. \& ZAMARREÑo, I. 1990. Biostratigrafía y facies de la sucesión carbonatada del Silúrico superior y Devónico Inferior de Santa Creu d'Olorda (Cadenas Costeras Catalanas, NE de Espańa). Acta Geológica Hispánica 25(1-2), 141-168.

García-López, S. \& Sanz-López, J. 2002. Devonian to Lower Carboniferous conodont biostratigraphy of the Bernesga Valley section (Cantabrian Zone, NW Spain), 163-205. In García-López, S. \& Bastida, F. (eds) Palaeozoic conodonts from northern Spain, Cuardernos del Museo Geominero No. 1. Instituto Geológico y Minero de Espańa, Madrid.

Gilligan, L.B. \& Byrnes, J.G. 1995. Cobar 1:250 000 metallogenic map SH/55-14: metallogenic study and mineral deposit data sheets. vi +240 pp. Geological Survey of New South Wales, Sydney.

GLEN, R.A. 1987. Geology of the Wrightville 1:100 000 sheet 8034. xv +257 pp. Geological Survey of New South Wales, Sydney.

GLEN, R.A. 1990. Formation and inversion of transtensional basins in the western part of the Lachlan Fold Belt, Australia, with emphasis on the Cobar Basin. Journal of Structural Geology 12, 601-620. DOI 10.1016/0191-8141(90)90077-C

GLEN, R.A. 1991. Inverted transtensional basin setting for gold and copper and base metal deposits at Cobar, New South Wales. BMR Journal of Australian Geology and Geophysics $12,13-24$.

Glen, R.A., Clare, A.P. \& Spencer, R. 1996. Extrapolating the Cobar Basin model to the regional scale: Devonian basin formation and inversion in western New South Wales, 43-83. In Cook, W.G., Ford, A.J.H., McDermott, J.J., Standish, P.N., 
Stegman, C.L. \& Stegman, T.N. (eds) The Cobar mineral field - a 1996 perspective. Australasian Institute of Mining and Metallurgy, Carlton, Victoria.

Glen, R.A., Drummond, B.J., Goleby, B.R., Palmer, D. \& WAKE-DysteR, K.D. 1994. Structure of the Cobar Basin, New South Wales, based on seismic reflection profiling. Australian Journal of Earth Sciences 41, 341-352.

DOI 10.1080/08120099408728143

GöNCÜOĞLU, Y. \& KozUR, H.W. 2000a. Early Devonian transgression in the eastern Antalya nappes: conodont data from the Tahtalidag Nappe, north of Alanya, southern Turkey. Records of the Western Australian Museum Supplement 58, 279-292.

GöNCÜOĞLu, Y. \& KozUR, H.W. 2000b. Early Silurian sea-level changes in southern Turkey: lower Telychian conodont data from the Kemer area, western Taurides. Records of the Western Australian Museum Supplement 58, 293-303.

Hass, W.H. 1959. Conodonts from the Chappel Limestone of Texas. United States Geological Survey Professional Paper 294J, 365-400.

JentzsCH, I. 1962. Conodonten aus dem Tentaculitenknollenkalk (Unterdevon) in Thüringen. Geologie 11, 961-985.

JEPPSSON, L. 1975. Aspects of late Silurian conodonts. Fossils and Strata 6, 1-54. [Imprint 1974]

JEPPSSON, L. 1988. Conodont biostratigraphy of the Silurian-Devonian boundary stratotype at Klonk, Czechoslovakia. Geologica et Palaeontologica 22, 21-33.

Jeppsson, L., Talent, J.A., Mawson, R., Simpson, A.J., Andrew, A.S., CALner, M., Whitford, D.J., Trotter, J.A., SANDStrÖM, O. \& CALDON, H.-J. 2007. High-resolution late Silurian correlations between Gotland, Sweden, and the Broken River region, NE Australia: lithologies, conodonts and isotopes. Palaeogeography, Palaeoclimatology, Palaeoecology 245, 115-137. DOI 10.1016/j.palaeo.2006.02.032

KAUfMAN, B. 2006. Calibrating the Devonian timescale: a synthesis of U-Pb ID-TIMS ages and conodont stratigraphy. Earth-Science Reviews 76(3-4), 175-190. DOI 10.1016/j.earscirev.2006.01.001

Khalifa, М.Кн. 2005. Geological and geophysical evaluation and interpretation of the Blantyre Sub-basin, Darling Basin, New South Wales. Ph.D. thesis, University of New South Wales, Sydney.

Khalifa, M.KH., Jones, B.G. \& Hlal, O. 2015. Sedimentary facies analysis and paleogeographic significance of the latest Silurian to Early Devonian Winduck Interval in the Darling Basin, western New South Wales, Australia. Australian Journal of Earth Sciences 62, 307-330.

DOI 10.1080/08120099.2015.1020449

Kim, A.I., Erina, M.V. \& KIM, L.A. 2008. Atlas of the paleontological plates, supplement to a guidebook of the field excursion. International Conference on: Global Alignments of Lower Devonian Carbonate and Clastic Sequences (SDS/IGCP 499 Project joint field meeting). Kitab State Geological Reserve, Uzbekistan August 25-September 3, 2008. Unpaginated. Tashkent.

KlapPer, G. (with a contribution by Ormiston, A.R.) 1969. Lower Devonian conodont sequence, Royal Creek, Yukon Territory, and Devon Island, Canada. Journal of Paleontology 43(1), 1-27.

KLAPPER, G. (with contributions from Johnson, D.B.) 1977. Lower and Middle Devonian conodont sequence in central Nevada, 33-53. In Murphy, M.A., Berry, W.B.N. \& SANDBERG, C.A. (eds) Western North America: Devonian,
University of California, Riverside, Campus Museum Contributions 4.

KLAPPER, G. 1981. Family Distomodontidae Klapper, new, 137. In Robison, R.A. (ed.) Treatise on invertebrate paleontology. Part W. Miscellanea. Supplement 2. Condonta. Geological Society of America \& University of Kansas, Boulder \& Lawrence.

Klapper, G., Austin, R.L. \& Rhodes, F.H.T. 1981. Family Polygnathidae Bassler, 1925, 162-166. In RoBison, R.A. (ed.) Treatise on invertebrate paleontology. Part W. Miscellanea. Supplement 2. Condonta. Geological Society of America \& University of Kansas, Boulder \& Lawrence.

KLAPPER, G. \& BARRICK, J.E. 1983. Middle Devonian (Eifelian) conodonts from the Spillville Formation in northern Iowa and southern Minnesota. Journal of Paleontology 57, 1212-1247.

KLAPPER, G. \& JohnSON, J.G. 1975. Sequence in conodont genus Polygnathus in Lower Devonian at Lone Mountain, Nevada. Geologica et Palaeontologica 9, 65-83.

KLAPPER, G. \& Johnson, J.G. 1980. Endemism and dispersal of Devonian conodonts. Journal of Paleontology 54, 400-455.

KLAPPER, G. \& Murphy, M.A. 1975. Silurian-Lower Devonian conodont sequence in the Roberts Mountains Formation of central Nevada. University of California Publications in Geological Sciences 111, 1-62. [Imprint 1974.]

Klapper, G. \& Murphy, M.A. 1980. Conodont zonal species from the delta and pesavis zones (Lower Devonian) in central Nevada. Neues Jahrbuch für Geologie und Paläontologie, Monatschefte 1980, 490-504.

KLAPPER, G. \& PhiLIP, G.M. 1972. Familial classification of reconstructed Devonian conodont apparatuses. Geologica et Palaeontologica SB1, 97-114

KLEFFner, M.A., BARRick, J.E., Ebert, J.R., Matteson, D.K. \& Karlsson, H.R. 2009. Conodont biostratigraphy, $\delta^{13} \mathrm{C}$ chemostratigraphy, and recognition of Silurian/Devonian boundary in the Cherry Valley, New York region of the Appalachian Basin. Paleontographica Americana 62, 57-73.

Kozur, H. 1998. The age of the siliciclastic series ("Karareis Formation") of the western Karaburun Peninsula, western Turkey. Palaeontologia Polonica 58, 171-189.

LANE, H.R. \& Ormiston, A.E. 1979. Siluro-Devonian biostratigraphy of the Salmontrout River area, east-central Alaska. Geologica et Palaeontologica 13, 39-96.

LinDSTRÖM, M. 1970. A suprageneric taxonomy of the conodonts. Lethaia 3, 427-445. DOI 10.1111/j.1502-3931.1970.tb00834.x

LiNK, A.G. \& DRUCE, E.C. 1972. Ludlovian and Gedinnian conodont stratigraphy of the Yass Basin, New South Wales. Bulletin of the Bureau of Mineral Resources, Geology and Geophysics 134, 1-136.

Lloyd, A.C. 1936. Geological survey of the Cobar district. Progress report. New South Wales Department of Mines Annual Report for 1935, 87-89.

Lu, J.-F., QIE, W.-Q. \& ChEN, X.-Q. 2016. Pragian and lower Emsian (Lower Devonian) conodonts from Liujing, Guangxi, South China. Alcheringa 40, 275-296. DOI 10.1080/03115518.2016.1129490

MaCRAE, G.P. 1987. Geology of the Nymagee 1:100 000 sheet 8133. viii +137 pp. Geological Survey of New South Wales, Sydney.

MacRAe, G.P. 1989a. Geology of the Lachlan Downs 1:100 000 sheet 8033. v +86 pp. Geological Survey of New South Wales, Sydney. 
MacRae, G.P. 1989b. Lachlan Downs 1:100,000 geological sheet 8033. Geological Survey of New South Wales, Sydney.

Männik, P., Bogolepova, O.K., Põldvere, A. \& Gubanov, A.P. 2009. New data on Ordovician-Silurian conodonts and stratigraphy from the Severnaya Zemlya Archipelago, Russian Arctic. Geological Magazine 146(4), 497-516. DOI 10.1017/S0016756809006372

MÄNNIK, P., LOYdelL, D.K. \& LubESEDER, S. 2011. Sheinwoodian (Silurian) conodonts and graptolites from NE Anti-Atlas, Morocco. Lethaia 44, 410-416. DOI 10.1111/j.1502-3931.2010.00249.x

MänNiK, P. \& MAŁKowsKi, K. 1998. Silurian conodonts from the Gołdap core, Poland. Palaeontologia Polonica 58, 141-151.

Männik, P., Miller, C.G. \& Hairapetian, V. 2013. Conodonts from the Niur Formation (Silurian) of the Derenjal Mountains, central Iran. Geological Magazine 150(4), 639-650. DOI 10.1017/S001675681200088X

Martín-Algarra, A., Mazzoli, S., Perrone, V., Rodríguez-Cañero, R. \& NAvas-Parejo, P. 2009. Variscan tectonics in the Malaguide Complex (Betic Cordillera, southern Spain): stratigraphic and structural Alpine verses pre-Alpine constraints from the Ardales area (Province of Malaga). I. Stratigraphy. Journal of Geology 117(3), 241-262. DOI 10.1086/597364

Mathieson, D. 2006. Early Devonian (Pragian) conodonts and silicified faunas from western New South Wales. M.Sc. thesis, Macquarie University, Sydney.

Mavrinskaya, T. \& Slavík, L. 2013. Correlation of Early Devonian (Lochkovian-early Pragian) conodont faunas of the South Urals (Russia). Bulletin of Geosciences 88(2), 283-296. DOI 10.3140/bull.geosci.1404

Mawson, R. 1986. Early Devonian (Lochkovian) conodont faunas from Windellama, New South Wales. Geologica et Palaeontologica 20, 39-71.

Mawson, R. 1987. Early Devonian conodont faunas from Buchan and Bindi, Victoria, Australia. Palaeontology 30, 251-297.

Mawson, R. 1998. Thoughts on late Pragian-Emsian polygnathid evolution: documentation and discussion. Palaeontologia Polonica 58, 201-211.

Mawson, R. \& TALent, J.A. 1994. Age of an Early Devonian carbonate fan and isolated limestone clasts and megaclasts, east-central Victoria. Proceedings of the Royal Society of Victoria 106, 31-70.

Mawson, R. \& Talent, J.A. 2000. The Devonian of eastern Australia: stratigraphic alignments, stage and series boundaries, and the transgression - regression pattern re-considered. Courier Forschungsinstitut Senckenberg 225, 243-270.

Mawson, R. \& Talent, J.A. 2003. Conodont faunas from sequences on or marginal to the Anakie Inlier (central Queensland, Australia) in relation to Devonian transgressions. Bulletin of Geosciences 78, 335-358.

Mawson, R., Talent, J.A., Bear, V.C., Benson, D.S., Brock, G.A., Farrell, J.R., Hyland, K.A., Pyemont, B.D., Sloan, T.R., Sorentino, L., Stewart, M.I., Trotter, J.A., Wilson, G. \& Simpson, A. 1988. Conodont data in relation to resolution of stage and zonal boundaries for the Devonian of Australia. Memoir of the Canadian Society of Petroleum Geologists 14, 485-527.

Mawson, R., Talent, J.A., Brock, G.A. \& Engelbretsen, M.J. 1992. Conodont data in relation to sequences about the Pragian-Emsian boundary (Early Devonian) in south-eastern
Australia. Proceedings of the Royal Society of Victoria 104, 23-56.

Mawson, R., Talent, J.A., Molloy, P.D. \& Simpson, A.J. 2003. Latest Silurian and Early Devonian (Pridoli-Lochkovian and early Emsian) conodonts from the Nowshera area, Pakistan: implications for the mid-Palaeozoic stratigraphy of the Peshawar Basin. Courier Forschungsinstitut Senckenberg 245, 83-105.

MilLER, C.G. 1995. Ostracode and conodont distribution across the Ludlow/Prídolí boundary of Wales and the Welsh Borderland. Palaeontology 38, 341-384.

Miller, C.G. \& AldRIDGe, R.J. 1993. The taxonomy and apparatus structure of the Silurian distomodontid conodont Coryssognathus Link \& Druce, 1972. Journal of Micropalaeontology 12, 241-255. DOI 10.1144/jm.12.2.241

Miller, C.G. \& MÄrss, T. 1999. A conodont, thelodont and acanthodian fauna from the lower Přídolí (Silurian) of the Much Wenlock area, Shropshire. Palaeontology 42(4), 691-784. DOI 10.1111/1475-4983.00093

Mulholland, C. St J. 1940. Geology and underground water resources of the East Darling district. Geological Survey of New South Wales, Mineral Resources 39, 1-80.

MüLLER, K.J. \& MüLlER, E.M. 1957. Early Upper Devonian (Independence) conodonts from Iowa, Part 1. Journal of Paleontology 30, 1324-1340.

Murphy, M.A. 1989. Lower Pragian boundary (Lower Devonian) and its application in Nevada. Courier Forschungsinstitut Senckenberg 117, 61-70.

Murphy, M.A. 2005. Pragian conodont zonal classification in Nevada, western North America. Revista Española de Paleontología 20 (2), 177-206.

Murphy, M.A. \& CebecioĞLu, M.K. 1984. The Icriodus steinachensis and I. claudiae lineages (Devonian conodonts). Journal of Paleontology 58, 1399-1411.

Murphy, M.A. \& MatTI, J.C. 1982. Lower Devonian conodonts (hesperius-kindlei zones), central Nevada. University of California Publications in Geological Sciences 123, 1-81.

Murphy, M.A., Matti, J.C. \& Walliser, O.H. 1981. Biostratigraphy and evolution of the Ozarkodina remscheidensis-Eognathodus sulcatus lineage (Lower Devonian) in Germany and central Nevada. Journal of Paleontology 55, 747-772.

Murphy, M.A. \& Valenzuela-Ríos, J.I. 1999. Lanea new genus, lineage of Early Devonian conodonts. Bollettino della Società Paleontologica Italiana 37, 321-334.

Murphy, M.A., Valenzuela-Ríos, J.I. \& Carls, P. 2004. On classification of Pridoli (Silurian)-Lochkovian (Devonian) Spathognathodontidae (conodonts). University of California, Riverside, Campus Museum Contributions 6, 1-25.

Pedder, A.E.H., Jackson, J.H. \& Philip, G.M. 1970. Lower Devonian biostratigraphy in the Wee Jasper region of New South Wales. Journal of Paleontology 44, 206-251.

Percival, I.G. 1998. The age of the Nandillyan and Narragal limestones, Molong High, central western New South Wales. Geological Survey of New South Wales, Quarterly Notes 107, 12-19.

PhiLIP, G.M. 1965. Lower Devonian conodonts from the Tyers area, Gippsland, Victoria. Proceedings of the Royal Society of Victoria 79, 95-117.

PhiLIP, G.M. 1966. Lower Devonian conodonts from the Buchan Group, eastern Victoria. Micropaleontology 12, 441-460. DOI $10.2307 / 1484789$ 
Pickett, J.W. 1976. A conodont fauna from the Kopyje Beds. Geological Survey of New South Wales, Palaeontological Report 76(12), 1-3.

PicketT, J.W. 1979. Conodont assemblages from the Amphitheatre, Baledmund and Meryula formations, and Great Cobar Slate, Cobar district. Geological Survey of New South Wales, Palaeontological Report 79(17), 1-3.

PicketT, J.W. 1980. Conodont assemblages from the Cobar Supergroup (Early Devonian), New South Wales. Alcheringa 4, 67-88. DOI 10.1080/03115518008558981

PicketT, J.W. 1981. Conodont assemblages from the "Lerida Limestone Member", Amphitheatre Group. Geological Survey of New South Wales, Palaeontological Report 81(2), 1-3.

PicketT, J.W. 1982. Colour alteration index of conodonts from the Cobar Super-Group. Geological Survey of New South Wales, Palaeontological Report 82(9), 1-2.

PicketT, J.W. 1983. Conodont assemblages from the Mountain Dam Limestone. Geological Survey of New South Wales, Palaeontological Report 83(10), 1-5.

Pickett, J.W. 1984. Early Devonian conodonts from Beulah Tank, Manuka, via Cobar. Geological Survey of New South Wales, Palaeontological Report 84(9), 1-2.

PicketT, J.W. 1986. Early Devonian conodonts from limestones in the Gundaroo Sandstone on Manuka Station. Geological Survey of New South Wales, Palaeontological Report 86(1), $1-3$.

PiCKETT, J.W. 1987. An Early Devonian conodont fauna from the Gunderbooka district. Geological Survey of New South Wales, Palaeontological Report 87(2), 1-2.

Pickett, J.W. 1992. Review of selected Silurian and Devonian conodont assemblages from the Mineral Hill-Trundle area. Geological Survey of New South Wales, Palaeontological Report 92(1), 1-9.

PicKetT, J.W. \& InGPEN, I.A. 1990. Ordovician and Silurian strata south of Trundle, New South Wales. Quarterly Notes, Geological Survey of New South Wales 78, 1-14.

Pickett, J. \& McClatchie, L. 1991. Age and relations of stratigraphic units in the Murda Syncline area. Quarterly Notes, Geological Survey of New South Wales 85, 9-32.

Pogson, D.J. \& Felton, E.A. 1978. Reapprasial of geology, Cobar-Canbelego-Mineral Hill region, central western New South Wales. Quarterly Notes, Geological Survey of New South Wales 33, 1-14.

Pyle, L.J. \& BARNES, C.R. 2003. Conodonts from a platform-to-basin transect, Lower Ordovician to lower Silurian, northeastern British Columbia, Canada. Journal of Paleontology 77(1), 146-171. DOI 10.1017/s0022336000043493

RAYNER, E.O. 1969. The copper ores of the Cobar region, New South Wales. Memoirs of the Geological Survey of New South Wales, Geology 10, 1-131.

RhodEs, F.H.T. 1953. Some British lower Palaeozoic conodont faunas. Royal Society of London, Philosophical Transactions Series B 237, 261-334. DOI 10.1098/rstb.1953.0005

Rickards, R.B., Percival, I.G., Simpson, A.J. \& Wright, A.J. 2001. Silurian biostratigraphy of the Cadia area, south of Orange, New South Wales. Proceedings of the Linnean Society of New South Wales 123, 173-191.

Rodríguez-Cañero, R., Navas-Parejo, P., Somma, R., MartínAlgarra, A. \& Perrone, V. 2013. First finding of upper Silurian and Lower Devonian conodonts from the Peloritani Mountains (NE Sicily, southern Italy). Bollettino della Società Paleontologica Italiana 52(2), 113-121.
SAvage, N.M. 1977. Lower Devonian conodonts from Karheen Formation, southeastern Alaska. Canadian Journal of Earth Sciences 14, 278-284. DOI 10.1139/e77-029

SAVAGE, N.M. 1985. Silurian (Llandovery-Wenlock) conodonts from the base of the Heceta Limestone, southeastern Alaska. Canadian Journal of Earth Sciences 22, 711-727. DOI 10.1139/e85-077

Savage, N.M., Blodgett, R.B. \& Jaeger, H. 1985. Conodonts and associated graptolites from the late Early Devonian of east-central Alaska and western Yukon Territory. Canadian Journal of Earth Sciences 22, 1880-1883.

DOI 10.1139/e85-200

Savage, N.M., Churkin, M. JR. \& Eberlein, G.D. 1977. Lower Devonian conodonts from Port St Nicholas, southeastern Alaska. Canadian Journal of Earth Sciences 14, 2928-2936. DOI $10.1139 / \mathrm{e} 77-253$

SAVAGe, N.M. \& Gehrels, G.E. 1984. Early Devonian conodonts from Prince of Wales Island, southeastern Alaska. Canadian Journal of Earth Sciences 21(12), 1415-1425. DOI 10.1139/e84-148

Serpagli, E., Corradini, C. \& Ferretti, A. 1998. Conodonts from a Ludlow-Př́idolí section near the Silius village. Giornale di Geologia, series 3a 60, 104-111.

Serpagli, E., Corradini, C. \& Olivieri, R. 1997. Occurrence and range of the Silurian conodont Coryssognathus dubius (Rhodes, 1953) in southern Sardinia. Bollettino della Società Paleontologica Italiana 35(3), 239-243.

Sharp, T.R. 1992. Mapping of the Devonian sequence at Mount Gunderbooka north of Cobar with emphasis on stratigraphy and sedimentology. B.Sc. (Hons) thesis, University of Technology, Sydney.

SHERwin, L. 1975. Siluro-Devonian fossils from the Bobadah and Melrose districts. Geological Survey of New South Wales, Palaeontological Report 75(8), 1-2.

SHERwIN, L. 1978a. Fossils from the Wrightville 1:100 000 sheet, No. 3. Geological Survey of New South Wales, Palaeontological Report 78(11), 1-2.

SHERwin, L. 1978b. Fossils from the Wrightville 1:100 000 sheet, No. 4. Geological Survey of New South Wales, Palaeontological Report 78(14), 1-2.

SHERwin, L. 1980. Faunal correlation of the Siluro-Devonian units Mineral Hill-Trundle-Peak Hill area. Quarterly Notes, Geological Survey of New South Wales 39, 1-14.

SHERwIN, L. 1995. Siluro-Devonian brachiopods from the Amphitheatre and Winduck groups (Cobar Supergroup), western New South Wales. Memoirs of the Association of Australasian Palaeontologists 18, 61-96.

SHERWIN, L. 1996. Narromine 1:250 000 geological sheet SI/55-3, explanatory notes. iiv $+104 \mathrm{pp}$. Geological Survey of New South Wales, Sydney.

SimPSON, A. 1995. Silurian conodont biostratigraphy in Australia: a review and critique. Courier Forschungsinstitut Senckenberg 182, 325-345.

Simpson, A. 2000. Silurian to basal Devonian conodonts from the Broken River Crossing, northeastern Australia. Records of the Western Australian Museum Supplement 58, 145-162.

Simpson, A., Bell, K.N., Mawson, R. \& Talent, J.A. 1993. Late Silurian (Ludlow) conodonts and foraminifers from Cowombat, SE Australia. Memoirs of the Association of Australasian Palaeontologists 15, 141-159.

Simpson, A.J. \& TAlent, J.A. 1995. Silurian conodonts from the headwaters of the Indi (upper Murray) and Buchan rivers, 
southeastern Australia, and their implications. Courier Forschungsinstitut Senckenberg 182, 79-215.

Slavík, L. 2001. Lower Devonian conodonts from the Karlík Valley and Na Branžovech sections in the Barrandian area, Czech Republic, and their significance for Pragian conodont zonation. Acta Geologica Polonica 51(3), 243-271.

SLAVík, L. 2004a. A new conodont zonation of the Pragian Stage (Lower Devonian) in the stratotype area (Barrandian, central Bohemia). Newsletters on Stratigraphy 40(1-2), 39-71. DOI 10.1127/0078-0421/2004/0040-0039

SLAVík, L. 2004b. The Pragian-Emsian conodont successions of the Barrandian area: search for an alternative to the GSSP polygnathid-based correlation concept. Geobios 37, 454-470. DOI 10.1016/j.geobios.2003.05.002

SLAVÍK, L. 2011. Lanea carlsi conodont apparatus reconstruction and its significance for subdivision of the Lochkovian. Acta Palaeontologica Polonica 56(2), 313-327. DOI 10.4202/app.2009.0046

Slavík, L. \& CARLS, P. 2012. Post-Lau Event (late Ludfordian, Silurian) recovery of conodont faunas in Bohemia. Bulletin of Geosciences 87(4), 815-832. DOI 10.3140/bull.geosci.1368

Slavík, L. \& HLadil, J. 2004. Lochkovian/Pragian GSSP revisited: evidence about conodont taxa and their stratigraphic description. Newsletters on Stratigraphy 40(3), 137-153. DOI 10.1127/0078-0421/2004/0040-0137

Slavík, L., KŘíž, J. \& CARls, P. 2010. Reflection of the mid-Ludfordian Lau Event in conodont faunas of Bohemia. Bulletin of Geosciences 85(3), 395-414.

DOI 10.3140/bull.geosci.1204

Slavík, L., Valenzuela-Ríos, J.I., Hladil, J. \& Carls, P. 2007. Early Pragian conodont-based correlations between the Barrandian area and the Spanish Pyrenees. Geological Journal 42, 499-512. DOI 10.1002/gj.1087

SLOAN, T.R. 2003. Results of a new outline-based method for the differentiation of conodont taxa. Courier Forschungsinstitut Senckenberg 245, 389-405.

Sloan, T.R., Talent, J.A., Mawson, R., Simpson, A.J., Brock, G.A., Engelbretsen, M.J., Jell, J.S., Aung, A.K., Pfaffenritter, C., Trotter, J. \& Withnall, I.W. 1995. Conodont data from Silurian-Middle Devonian carbonate fans, debris flows, allochthonous blocks and adjacent autochthonous platform margins: Broken River and Camel Creek areas, north Queensland, Australia. Courier Forschungsinstitut Senckenberg 182, 1-77.

Smith, J.V. \& Marshall, B. 1992. Patterns of folding and fold interference in oblique contraction of layered rocks of the inverted Cobar Basin, Australia. Tectonophysics 215, 319-334. DOI 10.1016/0040-1951(92)90359-E

Smith, M.P., Briggs, D.E. \& AldRIDGe, R.J. 1987. A conodont animal from the lower Silurian of Wisconsin, USA and the apparatus architecture of panderodontid conodonts, 91-104. In Aldridge, R.J. (ed.) Palaeobiology of conodonts. Ellis Horwood, Chichester.

Sobolev, N.N. 1994. Konodonty, 93-99. In Cherkesova, S.V. et al. (eds) Stratigrafiya $i$ fauna nizhnedevonskikh otlozhenii Tareiskogo opornogo razreza (Taimyr). Nedra, Sankt-Peterburg.

Sorentino, L. 1989. Conodont assemblages spanning the Lochkovian-Pragian (Early Devonian) boundary at Eurimbla, central New South Wales. Courier Forschungsinstitut Senckenberg 117, 81-115.
StaufFer, C.R. 1930. Conodonts from the Decorah Shale. Journal of Paleontology 4, 121-128.

STAufFer, C.R. 1940. Conodonts from the Devonian and associated clays of Minnesota. Journal of Paleontology 14, 417-435.

Stewart, J.R. \& Alder, J.D. (eds) 1995. New South Wales petroleum potential. Coal \& Petroleum Geology Branch Bulletin 1. 188 pp. New South Wales Department of Mineral Resources, Sydney.

SutTNER, T.J. 2007. Conodont stratigraphy, facies-related distribution patterns and stable isotopes (carbon and oxygen) of the uppermost Silurian to Lower Devonian Seewarte section (Carnic Alps, Carinthia, Austria). Abhandlungen der Geologischen Bundesanstalt 59, 1-111.

SutTNER, T.J. 2009. Lower Devonian conodonts of the "Baron Von Kottwitz" Quarry (southern Burgenland, Austria). Paleontographica Americana 62, 75-87.

SweEt, W.C. 1979. Late Ordovician conodonts and biostratigraphy of the western Midcontinent Province. Brigham Young University Geology Studies 26(3), 45-85.

SweET, W.C. 1988. The Conodonta: morphology, taxonomy, paleoecology, and evolutionary history of a long-extinct animal phylum. Oxford Monographs on Geology and Geophysics 10. 212 pp. Oxford University Press, Oxford.

Talent, J.A., Gaetani, M., Mawson, R., Molloy, P.D. \& Conaghan, P.J. (with a contribution from Lehnert, O. \& Trotter, J.A.) 1999. Early Ordovician and Devonian conodonts from the Western Karakoram and Hindu Kush, northernmost Pakistan. Rivista Italiana di Paleontologia $e$ Stratigrafia 105(2), 201-230.

Talent, J.A. \& Mawson, R. 1999. North-eastern Molong Platform and adjacent Hill End Trough, eastern Australia: midPalaeozoic conodont data and implications. Abhandlungen der Geologischen Bundesanstalt 54, 49-105.

Talent, J.A., Mawson, R., Aitchison, J.C., Becker, R.T., Bell, K.N., Bradshaw, M.A., Burrow, C.J., CoOK, A.G., Dargan, G.M., Douglas, J.G., Edgecombe, G.D., Feist, M., Jones, P.G., Long, J.A., Phillips-Ross, J.R., Pickett, J.W., Playford, G., Rickards, R.B., Webby, B.D., Winchester-Seeto, T., Wright, A.J., Young, G.C. \& Zhen, Y.-Y. 2000. Devonian palaeobiogeography of Australia and adjoining regions. Memoirs of the Association of Australasian Palaeontologists 23, 167-257.

TAlent, J.A., Mawson, R. \& Simpson, A.J. 2003. The "lost" Early Ordovician-Devonian Georgetown carbonate platform of northeastern Australia. Courier Forschungsinstitut Senckenberg 242, 71-79.

Talent, J.A., Mawson, R., Simpson, A.J. \& Brock, G. 2002. Palaeozoics of NE Queensland: Broken River region: Ordovician-Carboniferous of the Townsville hinterland: Broken River and Camel Creek regions, Burdekin and Clark river basins. IPC2002 field excursion guidebook. 82 pp. Macquarie University Centre for Ecostratigraphy and Palaeobiology Special Publication No. 1, Sydney.

Talent, J.A., Mawson, R. \& Winchester-Seeto, T. (with contributions from Molloy, P.D., Mathieson, D., BASDEn, A. \& Conaghan, P.J.) 2003. Final report for Eastern Star Gas and NSW Department of Mineral Resources: on information gleaned from Darling Basin cores. 147 pp. Unpublished report, Macquarie University Centre for Ecostratigraphy and Palaeobiology. [Open file: New South Wales Department of Mineral Resources] 
Talent, J.A., Simpson, A.J., Molloy, P.D. \& Mawson, R. 2005. Conodonts from the Wombat Creek Group and "Wibenduck Limestone" (Silurian) of eastern Victoria. Proceedings of the Royal Society of Victoria 115(1), 265-291.

ThomAs, L.A. 1949. Devonian-Mississipian formations of southeast Iowa. Bulletin of the Geological Society of America 60, 403-438.

DOI 10.1130/0016-7606(1949)60[403:DFOSI]2.0.CO;2

TRIGG, S.J. 1987. Geology of the Kilparney 1:100 000 sheet 8132. vii +131 pp. Geological Survey of New South Wales, Sydney.

Trotter, J.A. \& TAlent, J.A. 2005. Early Devonian (midLochkovian) brachiopod, coral and conodont faunas from Manildra, New South Wales, Australia. Palaeontographica, Abteilung A 273, 1-54.

Tucker, R.D., Bradley, D.C., Ver Straeten, C.A., Harris, A.G., Ebert, J.R. \& McCutcheOn, S.R. 1998. New U-Pb zircon ages and the duration and division of Devonian time. Earth and Planetary Science Letters 158, 175-186. DOI 10.1016/S0012-821X(98)00050-8

UyENo, T.T. 1980. Stratigraphy and conodonts of upper Silurian and Lower Devonian rocks in the environs of the Boothia Uplift, Canadian Arctic Archipelago. Part 2: Systematic study of conodonts. Geological Survey of Canada Bulletin 292, $39-75$.

Uyeno, T.T. (with contributions from MAYR, U. \& ROBLESKY, R.F.) 1990. Biostratigraphy and conodont faunas of Upper Ordovician through Middle Devonian rocks, Eastern Arctic Archipelago. Geological Survey of Canada Bulletin 401, 1-210.

Uyeno, T.T. 1991. Pre-Famennian Devonian conodont biostratigraphy of selected intervals in the eastern Canadian Cordillera. Geological Survey of Canada Bulletin 417, 129-161.

Uyeno, T.T. \& Bultynck, P. 1993. Lower to Middle Devonian conodonts of the Jaab Lake Well, Moose River Basin, northern Ontario. Geological Survey of Canada Bulletin 444, 7-35. DOI 10.4095/183978

Valentine, J.L., Cole, D.J. \& Simpson, A.J. 2006. Silurian linguliformean brachiopods and conodonts from the Cobra Formation, southeastern New South Wales, Australia. Proceedings of the Linnean Society of New South Wales 127, 199-234.

VALenZuela-Ríos, J.I. 1994. Conodontos del Lochkoviense y Praguiense (Devónico Inferior) del Pirineo Central Español. Memorias del Museo Paleontológico de la Universidad de Zaragoza 5, 1-178.

Valenzuela-Ríos, J.I., Liao, J.C., Martinez-Perez, C., Castello, V. \& Botella, H. 2005. Datos preliminares sobre los conodontos y restos de peces del Lochkoviense y Praguiense? (Devónico Inferior) de Comte-1 (Vale del Noguera Pallaressa Pirineos), 131-145. In GÁmeZ VinTANEd, J.A., LiÑÁN, E. \& VALENZUELA-Ríos, J.I. (eds) La cooperación internacional en la paleontología Española. Homenaje al Prof. Peter Carls. Jornadas Aragonesas de Paleontología 8. Institución "Fernando el Católico", Zaragoza.

VALENZUELA-Ríos, J.I. \& MurPhy, M.A. 1997. A new zonation of middle Lochkovian (Lower Devonian) conodonts and evolution of Flajsella n. gen. (Conodonta). Geological Society of America, Special Paper 321, 131-144.

DOI 10.1130/0-8137-2321-3.131

Valenzuela-Ríos, J.I., Slavík, L., Liao, J.-C., Calvo, H.,
HušKovÁ, A. \& Chadimová, L. 2015. The middle and upper Lochkovian (Lower Devonian) conodont successions in key peri-Gondwana localities (Spanish Central Pyrenees and Prague Synform) and their relevance for global correlations. Terra Nova 27, 409-415. DOI 10.1111/ter.12172

VIIRA, V. 1999. Late Silurian biostratigraphy in the northern East Baltic. Bollettino della Società Italiana 37 (2-3), 299-310.

Wall, R., Mawson, R., Talent, J.A. \& Cooper, B.J. 1995. Late Pragian conodonts from an environmentally hostile context, the Lilydale Limestone of central Victoria. Courier Forschungsinstut Senckenberg 182, 371-387.

WaLLiser, O.H. 1964. Conodonten des Silurs. Abhandlungen des Hessischen Landesamtes für Bodenforschung zu Wiesbaden 41, 1-106.

WANG, C.-Y. 1985. Silurian and Lower Devonian conodonts from Darhan Mumingan Joint Banner, Inner Mongolia, 153-164. In LI, W.-G., Rong, J.-Y. \& Dong, D.-Y. (eds) Silurian and Devonian rocks and faunas of the Bateaobao area in Darhan Mumingan Joint Banner, Inner Mongolia. People's Publishing House of Inner Mongolia. [In Chinese]

WANG, C.-Y. (with contributions from AldRIDGe, R.J.) 2013. Silurian conodonts in China. $230 \mathrm{pp}$. University of Science and Technology of China Press, Chinese Academy of Sciences, Hefei.

WANG, C.-Y. \& AldRIDGE, R.J. 2010. Silurian conodonts from the Yangtze Platform, South China. Special Papers in Palaeontology 83, 1-136.

WedDige, K. 1987. The lower Pragian boundary (Lower Devonian) based on the conodont species Eognathodus sulcatus. Senckenbergiana lethaea 67, 479-497.

Weddige, K., Ziegler, W. \& Minjin, C. 2005. New record of Devonian Lochkovian conodonts from the Tsagaanbulag Formation in the Shine Jinst area, South Mongolia. Acta Palaeontologica Sinica 44(1), 17-24.

WiLson, G.A. 1989. Documentation of conodont assemblages across the Lochkovian-Pragian (Early Devonian) boundary at Wellington, central New South Wales, Australia. Courier Forschungsinstut Senckenberg 117, 117-171.

WincheSTER-SEeto, T. \& CAREY, S.P. 2000. Chitinozoans and associated conodonts from the Early Devonian Point Hibbs Formation, Tasmania, Australia. Records of the Western Australian Museum Supplement 58, 163-177.

Yolkin, E.A., Kim, A.I., Weddige, K., Talent, J.A. \& House, M.R. 1997. Definition of the Pragian/Emsian boundary. Episodes 20, 235-240.

Yolkin, E.A., Kim, A.I., Weddige, K., Talent, J.A. \& House, M.R. 2000. The basal Emsian GSSP in Zinzil'ban Gorge, Uzbekistan. Courier Forschungsinstitut Senckenberg 225, $17-25$.

ZIEGLER, W. 1960. Conodonten aus dem Rheinischen Unterdevon (Gedinnium) des Remscheider Sattels (Rheinisches Schiefergebirge). Paläontologische Zeitschrift 34(2), 169-201. DOI 10.1007/BF02987050

ZiegLeR, W. (ed.) 1973. Catalogue of conodonts I. 504 pp. E. Schweizerbart'sche Verlagsbuchhandlung, Stuttgart.

Ziegler, W. (ed.) 1975. Catalogue of conodonts II. 404 pp. E. Schweizerbart'sche Verlagsbuchhandlung, Stuttgart.

ZIEGLER, W. (ed.) 1991. Catalogue of conodonts V. 212 pp. E. Schweizerbart'sche Verlagsbuchhandlung, Stuttgart. 